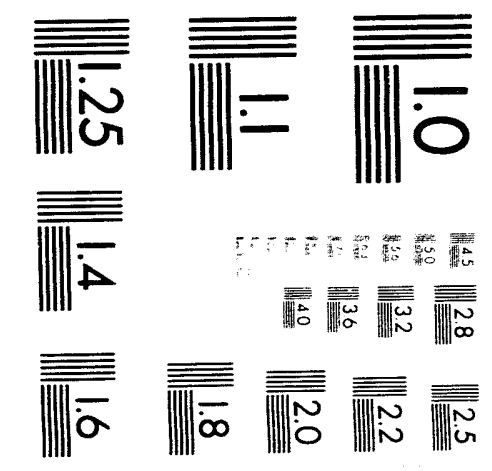



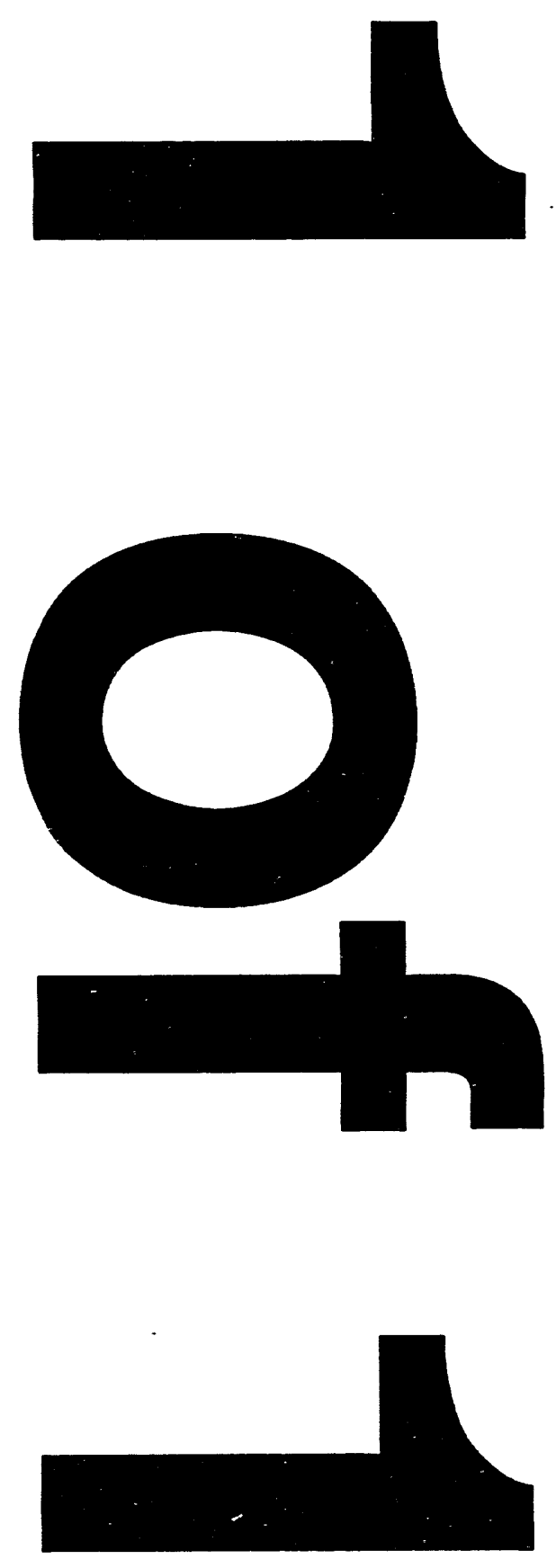


\title{
Coal-Fired High Performance Power Generating System
}

\author{
DE-AC22-92PC91155
}

Quarterly Progress Report

for the Period April 1 - June 30, 1993

Prepared for

\author{
Pittsburgh Energy Technology Center \\ Pittsburgh, Pennsylvania
}

\section{United Technologies Research Center \\ 411 Silver Lane, East Hartford, Connecticut 06108 \\ DISCLAIMER}

\begin{abstract}
This report was prepared as an account of work sponsored by an agency of the United States Government. Neither the United States Government nor any agency thareof, nor any of their employees, makes any warranty, express or implied, or assumes any legal liability or responsibility for the accuracy, completeness, or usefulness of any information, apparatus, product, or process disclosed, or represents that its use would not infringe privately owned rights. Reference herein to any specific commercial product, process, or service by trade name, trademark, manufacturer, or otherwise does not necessarily constitute or imply its endorsement, recommendation, or favoring by the United States Government or any agency thereof. The views and opinions of authors expressed herein do not necessarily state or reflect those of the United States Government or any agency thereof.
\end{abstract}

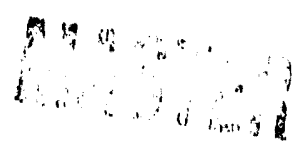




\section{CONTENTS}

$\underline{\text { Section }}$

EXECUTIVE SUMMARY $\ldots \ldots \ldots \ldots \ldots \ldots \ldots \ldots \ldots \ldots \ldots \ldots \ldots \ldots \ldots \ldots$

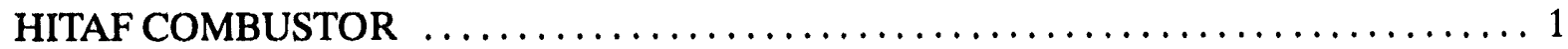

Combustor Modeling $\ldots \ldots \ldots \ldots \ldots \ldots \ldots \ldots \ldots \ldots \ldots \ldots \ldots \ldots \ldots \ldots \ldots \ldots \ldots \ldots \ldots \ldots$

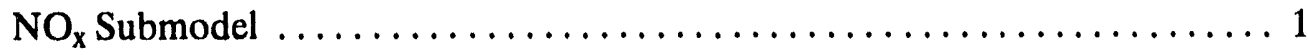

Slag-Layer Thickness Model $\ldots \ldots \ldots \ldots \ldots \ldots \ldots \ldots \ldots \ldots \ldots \ldots . \ldots 4$

HITAF CONVECTIVE AIR HEATER $\ldots \ldots \ldots \ldots \ldots \ldots \ldots \ldots \ldots \ldots \ldots \ldots$

CFD Analysis of Heat Fxchanger Designs $\ldots \ldots \ldots \ldots \ldots \ldots \ldots \ldots \ldots \ldots \ldots$

AIR HEATER MATERIALS $\ldots \ldots \ldots \ldots \ldots \ldots \ldots \ldots \ldots \ldots \ldots \ldots \ldots \ldots \ldots \ldots \ldots$

REFRACTORY - SLAG INTERACTIONS $\ldots \ldots \ldots \ldots \ldots \ldots \ldots \ldots \ldots \ldots \ldots \ldots \ldots$

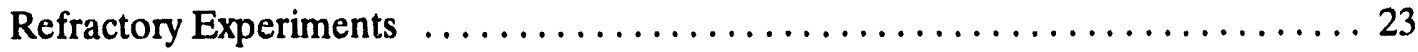

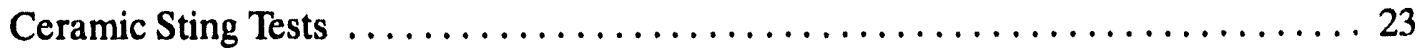

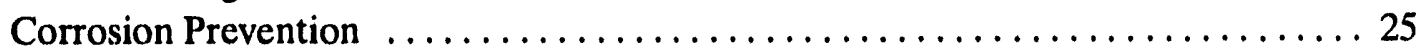

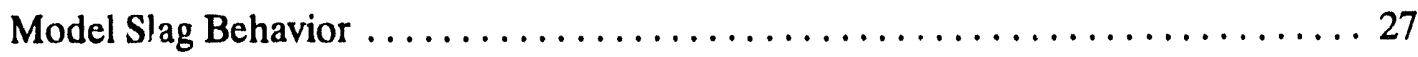

COMMERCIAL PLANT DESIGN $\ldots \ldots \ldots \ldots \ldots \ldots \ldots \ldots \ldots \ldots \ldots \ldots \ldots \ldots$

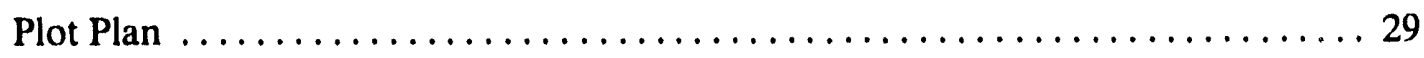

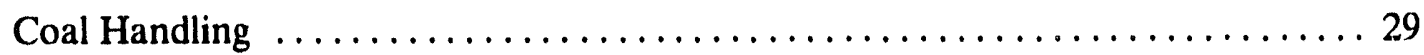

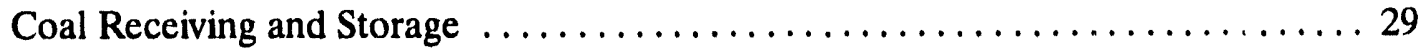

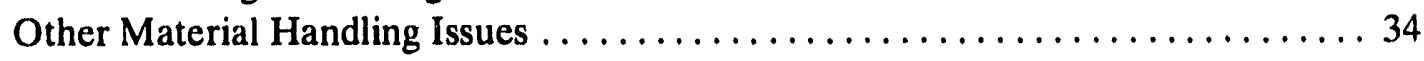

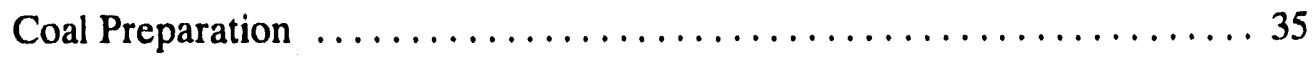

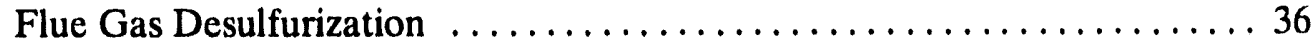

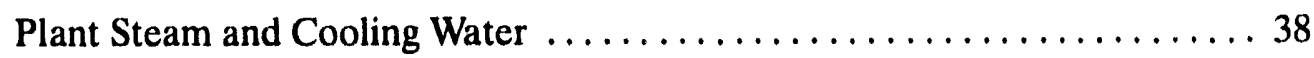

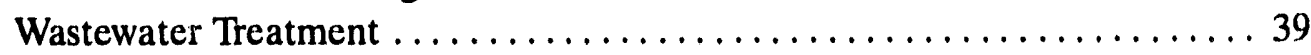

Auxiliary Power Consumption Estimate $\ldots \ldots \ldots \ldots \ldots \ldots \ldots \ldots$

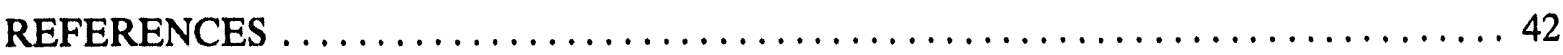

APPENDIX A - CONCEPTUAL DESIGN MAJOR EQUIPMENT LISTS $\ldots \ldots \ldots \ldots \ldots$ A-1 


\section{TABLES}

1. Compilation of fuel properties used for comparison with new NOx model. ..... 2

2. Ash particle size distribution at inlet of HITAF convective air heater. $\ldots \ldots \ldots 11$

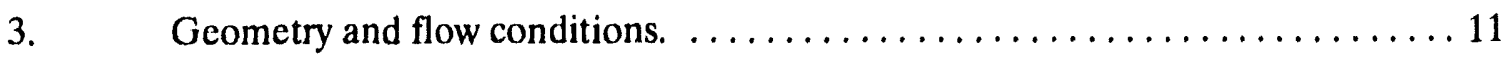

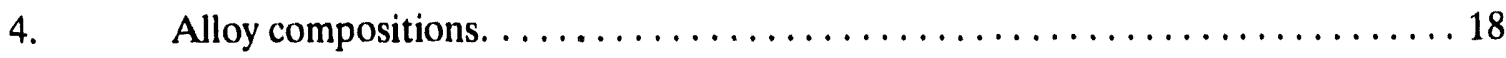

5. Technical data for Norton and A.P. green refractories. . . . . . . . . 23

6. Preliminary estimate of the auxiliary power requirements. $\ldots \ldots \ldots \ldots \ldots 41$

A-1. Major Equipment List, Coal Handling Preparation $\ldots \ldots \ldots \ldots \ldots \ldots \ldots$ A-1

A-2. Major Equipment List, Flue Gas Desulfurization $\ldots \ldots \ldots \ldots \ldots \ldots \ldots$ A-5

A-3. Major Equipment List, Plant Steam and Water $\ldots \ldots \ldots \ldots \ldots \ldots \ldots$ A-8 


\section{FIGURES}

Figure

1. Comparison of experimental exhaust $\mathrm{NO}$ values with predictions obtained using the existing NO submodel. . . . . . . . . . . . . . . . . . . . . . . . 3

2. Comparison of experimental exhaust $\mathrm{NO}$ values with predictions obtained using the improved NO submodel. $\ldots \ldots \ldots \ldots \ldots \ldots \ldots \ldots \ldots \ldots \ldots$

3. Model predictions of ash-thicknesses for the case of $25 \mathrm{~m}$ of adiabatic length. .. 6

4. Temperature predictions for the case of $25 \mathrm{~m}$ of adiabatic length. ........6

5. Model predictions of ash-thicknesses for the case of $15 \mathrm{~m}$ of adiabatic length. ... 7

6. Temperature predictions for the case of $15 \mathrm{~m}$ of adiabatic length. ........ 7

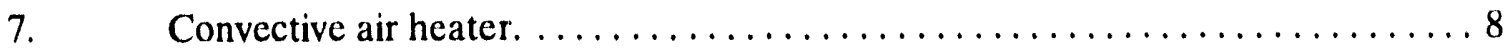

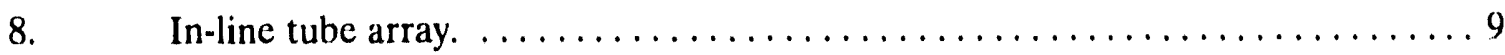

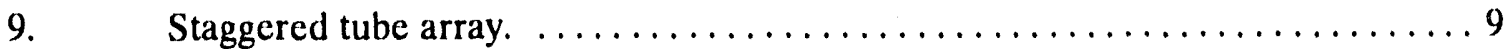

10. In-line tube array $-5: 1$ aspect ratio ellipsoidal tubes. $\ldots \ldots \ldots \ldots \ldots \ldots \ldots$

11. Staggered tube array $-5: 1$ aspect ratio ellipsoidal tubes. $\ldots \ldots \ldots \ldots \ldots \ldots 10$

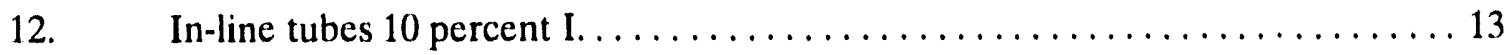

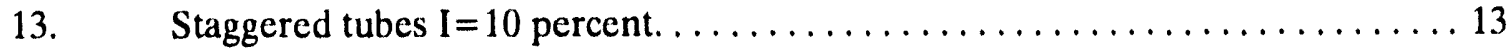

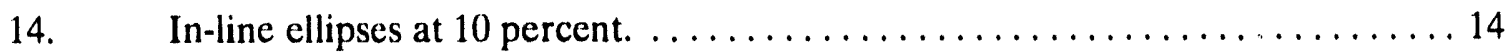

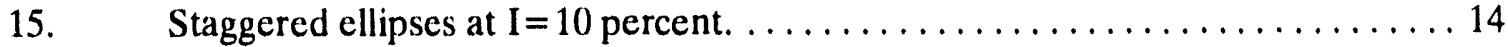

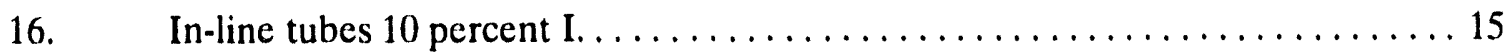

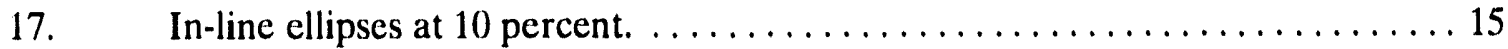

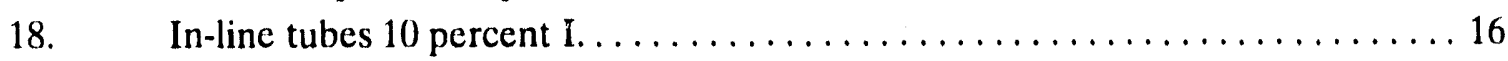

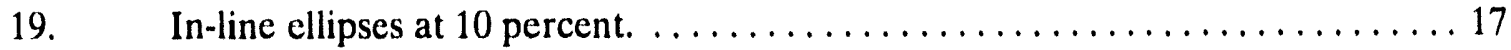

20. Room temperature tensile properties of various sheet alloys (oxide dispersion strengthened alloys tested parallel to rolling direction) $\ldots \ldots \ldots \ldots \ldots \ldots$

21. $982^{\circ} \mathrm{C}$ tensile properties of various sheet alloys (oxide dispersion strengthened

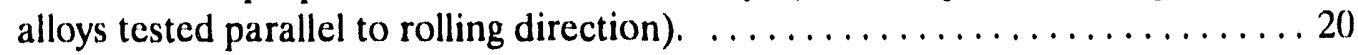

22. Formability range of various sheet alloys. . . . . . . . . . . . . . . . 20

23. Cyclic oxidation testing at $982^{\circ} \mathrm{C}\left(1800^{\circ} \mathrm{F}\right)-6$ minute cycle. $\ldots \ldots \ldots \ldots 21$

24. Hot spot blister thermal fatigue test cold wall cracking comparison. . . . . . . 22

25. $\quad 982^{\circ} \mathrm{C}\left(1800^{\circ} \mathrm{F}\right)$ rupture life of various sheet alloys (oxide dispersion strengthened

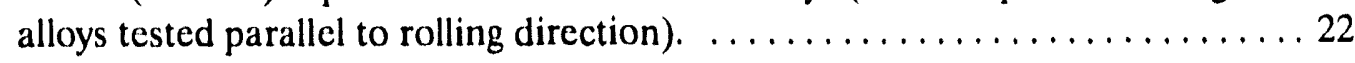

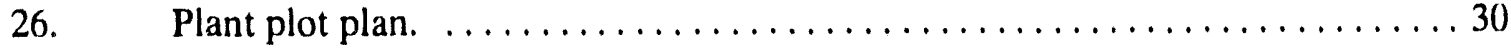

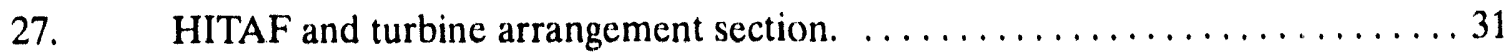

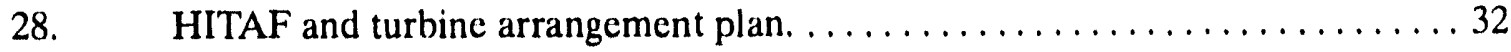

29. HITAF and turbine arrangement plan. . . . . . . . . . . . . . . . . 33

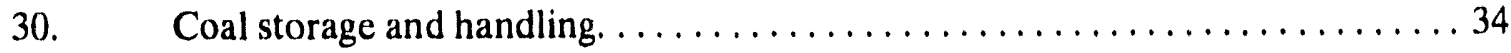

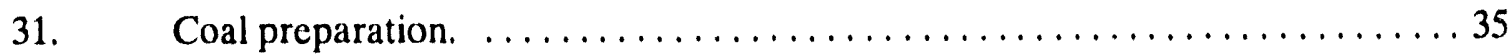

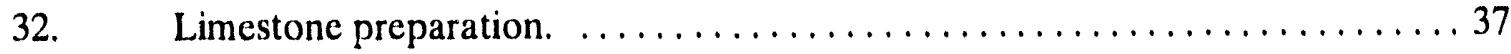

33. Wet limestone scrubbing with forced oxidation. $\ldots \ldots \ldots \ldots \ldots \ldots \ldots \ldots$ 


\section{EXECUTIVE SUMMARY}

This report covers work carried out under Task 2, Concept Definition and Analysis, Task 3, Preliminary R\&D and Task 4, Commercial Generating Plant Design, under Contract DE-AC22-92PC91155, "Engineering Development of a Coal Fired High Performance Power Generation System" between DOE Pittsburgh Energy Technology Center and United Technologies Research Center.

The goals of the program are to develop a coal-fired high performance power generation system (HIPPS) by the year 2000 that is capable of

- $>47 \%$ thermal efficiency

- $\mathrm{NO}_{\mathrm{x}}, \mathrm{SO}_{\mathrm{x}}$ and Particulates $\leq 25 \%$ NSPS

- cost $\geq 65 \%$ of heat input

- all solid wastes benign

In order to achieve these goals our team has outlined a research plan based on an optimized analysis of a $250 \mathrm{MW}_{\mathrm{e}}$ combined cycle system applicable to both frame type and aeroderivative gas turbines. Under the constraints of the cycle analysis we have designed a high temperature advanced furnace (HITAF) which integrates several combustor and air heater designs with appropriate ash management procedures.

The combustor modeling effort has been upgraded in two important aspects:

1. The $\mathrm{NO}_{\mathbf{x}}$ formation model has been improved to distinguish between fuel bound nitrogen originating from the volatiles or the char. Incorporating this distinction in the model allows for more accurate predictions of the rank dependence of $\mathrm{NO}_{\mathbf{x}}$ formation.

2. The incorporation of a temperature-dependent viscosity in the slag layer calculation. This improvement allows for more reliable heat balance/slag layer calculation over the range of operating conditions in both the adiabatic and radiant sections of the HITAF.

Design of the convective air heater has been advanced by the use of CFD modeling. The various contours discussed as options have been modelled and the impaction and disposition of ash particles can now be estimated for the different configurations.

A survey of currently available: high temperature alloys has been completed and some of their high temperature properties are shown for comparison. Several of the most promising candidates will be selected for testing to determine corrosion resistance and high temperature strength.

The corrosion resistance testing of candidate refractory coatings is continuing and some of the recent results are presented. This effort will provide important design information that will ultimately establish the operating ranges of the HITAF.

Preliminary drawings of the commercial plant design are presented along with the associated equipment lists. The costs for acquiring and constructing these designs is currently being determined. 


\section{HITAF COMBUSTOR}

\section{Combustor Modeling}

The design of the full-scale HITAF is unique and is thus outside the realm of current practical knowledge and experience. The are no empirical data to assist in the design of the full-scale unit, as is the case for more conventional, lower temperature boilers and furnaces. As a consequence, the most useful tool for analyzing the efficacy os various designs and determining the optimum design given the constraints of the program is an accurate computer simulation. In order to provide the most sophisticated tool possible for use in design of the HITAF, various improvements to the computer model have been undertaken in order to fully couple all of the important processes germane to this design.

\section{NO $O_{x}$ Submodel}

Predicting $\mathrm{NO}_{\mathrm{x}}$ formation in practical coal flames involves the complitational coupling of the many important aspects of chemistry and physics in a way that allows the realistic simulation of practical flames with reasonable computational effort. Such flames have a wide disparity of spatial and temporal scales. The current modeling ability of the comprehensive coal simulations is described in a previously published model of $\mathrm{NO}_{\mathbf{x}}$ formation, based primarily on the work of DeSoete (1975), that can be incorporated into coal combustion simulations (Smith et al., 1982). This model, however, has limitations in its ability to predict the influence of coal type on $\mathrm{NO}_{\mathrm{x}}$ emissions. The old model assumes that all fucl nitrogen evolves from the coal particle as $\mathrm{HCN}$ and in amounts proportional to the nitrogen content of the parent coal. It does not differentiate between: 1) the difference in nitrogen content of the volatiles and the char, or 2) the difference between the mechanisms of NO formation between char and volatiles. These limitations make accurate prediction of changes in coal on $\mathrm{NO}_{\mathrm{x}}$ formation difficult.

In order to provide a more physically descriptive $\mathrm{NO}_{\mathrm{x}}$ submodel for the comprehensive coal combustion simulations, a differentiation between nitrogen products evolving with the volatile material and nitrogen products evolved from the char was included in the simulation. The price, however, for this more detailed description is additional computation time.

\section{Previous Capabilities}

Existing bench-scale data on fuel NO formation (Chen et al., 1982) were used to test the capabilities of the existing and improved models. This experimental study investigated the influence of coal type on $\mathrm{NO}_{\mathrm{x}}$ formation from pulverized coal and more than 23 coals were included. A bench-scale, refractory-lined test facility fired at a rate of $21 \mathrm{~kW}_{\mathrm{t}}$ was utilized for the experimental comparisons and a premixed burner was used for the experimental results selected for evaluation of the new $\mathrm{NO}_{x}$ model. The various coals were burned in a molecular-nitrogen free atmosphere, simulated by a mixture of $\mathrm{O}_{2}, \mathrm{Ar}$ and $\mathrm{CO}_{2}$, to investigate the behavior of the NO resulting from 
oxidation of the fuel $\mathrm{N}$ only. The $\mathrm{CO}_{2} / \mathrm{Ar}$ ratio was selected to match the theoretical flame temperature that would be obtained for combustion in air.

Two pairs of coals were chosen for comparative purposes, two high-volatile bituminous coals and two lignitic coals, due to similaritics in raw coal nitrogen content and differences in exhaust NO measurements. An anthracite was also included for comparison. A summary of the coal properties and experimentally measured NO concentrations is given in Table 1. For the two bituminous coals, the percent nitrogen in the raw coal is very similar, yet the exhaust NO values differed by $400 \mathrm{ppm}$. For the lignites, the raw coal nitrogen is identical yet the resulting NO values differed by nearly $300 \mathrm{ppm}$. Due to the variance in exhaust NO values, these coals were selected for use in testing the abilities of the improved $\mathrm{NO}_{\mathrm{x}}$ model to account for coal effects; particularly the effect of char nitrogen.

Table 1. Compilation of fuel properties used for comparison with new $\mathrm{NO}_{\mathrm{x}}$ model.

\begin{tabular}{|c|c|c|c|c|c|}
\hline Source & $\begin{array}{l}\text { Price, } \\
\text { UT (II) }\end{array}$ & $\begin{array}{l}\text { Elkay, } \\
\text { WV }\end{array}$ & Savage, MT & Beulah, ND & Hazelton, PA \\
\hline $\begin{array}{l}\text { Proximate } \\
\text { Analysis }\end{array}$ & $\begin{array}{l}\text { (wt \% as } \\
\text { reccived) }\end{array}$ & & & & \\
\hline Moisture & 7.41 & 0.60 & 36.36 & 33.10 & 5.13 \\
\hline Ash & 8.83 & 11.61 & 4.61 & 7.12 & 5.74 \\
\hline Volatile & 38.84 & 33.35 & 28.48 & 28.65 & 4.39 \\
\hline Fixed C & 44.92 & 54.44 & 30.55 & 31.13 & 84.74 \\
\hline $\begin{array}{l}\text { Ultimate } \\
\text { Analysis }\end{array}$ & (wt \% dry) & & & & \\
\hline $\mathrm{C}$ & 72.24 & 73.96 & 64.99 & 65.29 & 88.45 \\
\hline $\mathrm{H}$ & 5.75 & 4.93 & 4.04 & 3.96 & 2.14 \\
\hline $\bar{N}$ & 1.55 & 1.39 & 1.00 & 0.99 & 0.79 \\
\hline$S$ & 0.76 & 2.47 & 0.42 & 1.14 & 0.47 \\
\hline Ash & 9.54 & 11.69 & 7.25 & 10.64 & 6.05 \\
\hline 0 & 10.16 & 5.56 & 22.30 & 17.98 & 2.10 \\
\hline $\begin{array}{l}\text { Heating Value } \\
(\mathrm{kJ} / \mathrm{kg}) \text { wet }\end{array}$ & 27,614 & 30,505 & 16,263 & 16,845 & 30,526 \\
\hline $\begin{array}{l}\text { ASTM } \\
\text { Classification }\end{array}$ & $\begin{array}{l}\text { Hi-Vol B } \\
\text { Bitum. }\end{array}$ & $\begin{array}{l}\text { Hi-Vol B } \\
\text { Bitum. }\end{array}$ & Lignite A & Lignite A & Anthracite \\
\hline $\begin{array}{l}\text { Exhaust Fuel } \\
\text { NO (dry ppm, } \\
\left.0 \% \mathrm{O}_{2}\right)\end{array}$ & 1230 & 850 & 1020 & 750 & 440 \\
\hline
\end{tabular}

Predictions with the existing model for these test cases are shown in Figure 1. Although the model is able to predict some of the trends, the result is not very satisfying if the practical engineer expects to make decision about coal selection or performance in a given furnace. The reason for this inadequacy is in the failure of the model to distinguish between fuel nitrogen that evolves in volatile 
tars or light gases and the char nitrogen. Solomon and Colket (1978), Pershing and Wendt (1979) and Pohl and Sarofim (1977) have shown that the nitrogen in the coal does not evolve uniformly with mass loss from the parent coal. Most of the nitrogen seems to be bound in aromatic structures that evolve from the parent coal at different rates for different coals even in the same rank (Pershing and Wendt, 1979). Thus in Figure 1, the two lignitic coals (Savage and Beulah) have quite different NO yields even though the original nitrogen content in the coal is similar. The same is true of the two bituminous coals (Utah and Elkay). The existing $\mathrm{NO}_{\mathrm{x}}$ model assumes all nitrogen to evolve from the coal uniformly with mass loss and at the composition of the original dry, ash-free coal. No distinction is made between volatile nitrogen content and char nitrogen content. As such, it cannot distinguish between the two coals in the same rank. Any differences in the predicted NO level in Figure 1, for the pairs in the same rank, are duc to the slight variation in the as-received coal composition.

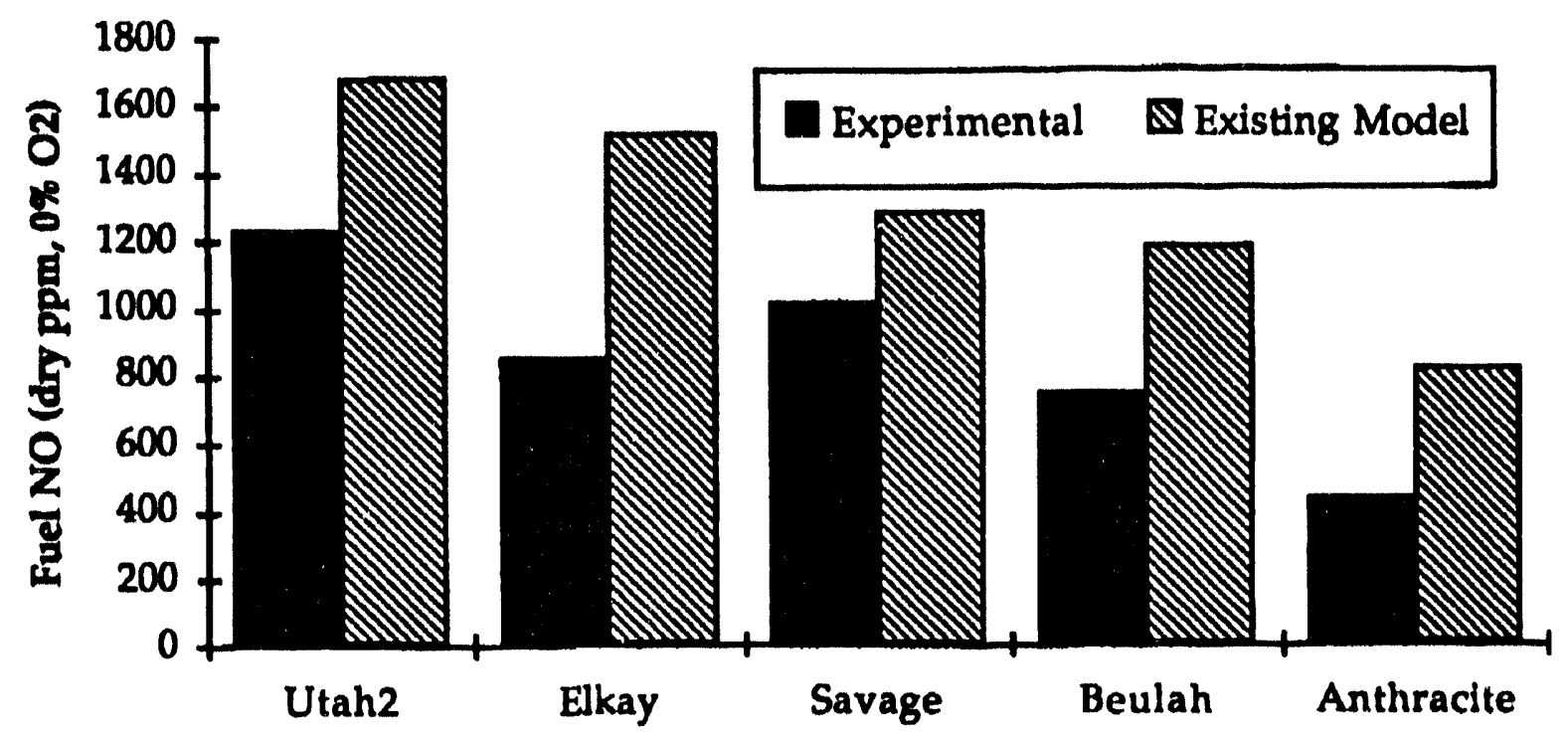

Figure 1. Comparison of experimental exhaust NO values with predictions obtained using the existing NO submodel.

New NOx Model Results

The cases reported by Chen et. al (1982) were simulated, as before, but with the new distinction between volatile and char nitrogen. Characterization of the coals was used as reported by Chen et. al where available. Additionally, the devolatilization process was modeled following Kobayashi (1977), with rates reported by Ubhayakar (1977) and with lower and upper volatile yields of the ASTM volatiles and twice that value. The nitrogen content of the volatile matter as distinguishable from the char nitrogen was reported for the the lignitic coals (Beulah and Savage) and for the anthracite. The original parent nitrogen content was used for both the bituminous coals and assumed to be equal for the volatiles and the char, since ،o data were available. The results are shown in Figure 2. 


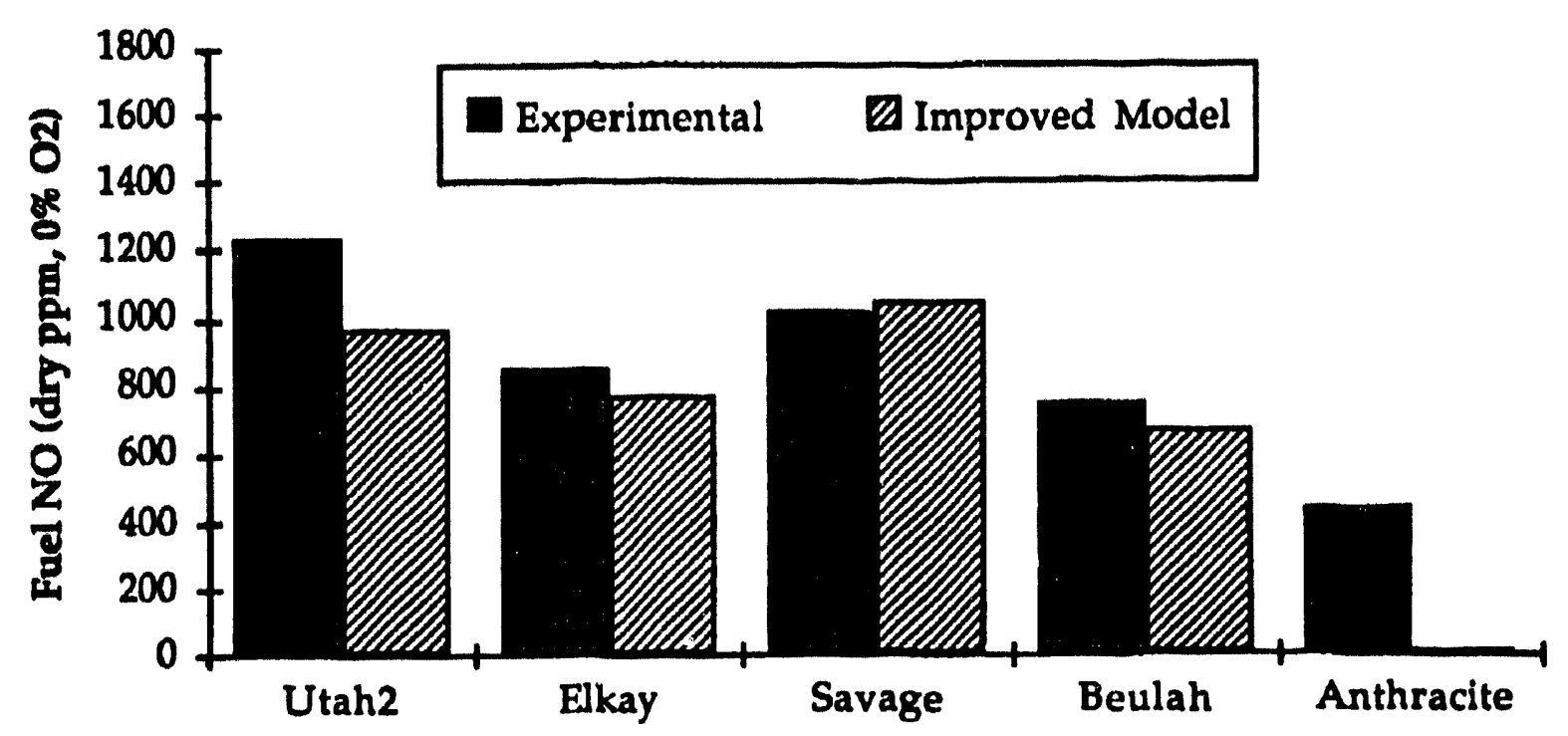

Figure 2. Comparison of experimental exhaust NO values with predictions obtained using the improved NO submodel.

The correct trend for all five coals is predicted. We would expect the simulition to be low since we have not yet included any mechanism for NO production from char nitrogen. The importance of this further improvement is particularly evident with the results for the anth/acite. The ASTM char accounted for approximately $95 \%$ of the raw coal (daf basis); therefore, char 'NO would be expected to be the dominant source of the measured NO. The simulation appears to support this as very little NO was predicted from volatiles alone.

The significant improvement over the predictions of Figure 1 are in the pairs of similar rank coals. Even when the raw coal nitrogen content is the same, the simulation and the measurements show different outlet NO concentrations. The comparison is best for the lignitic coals where we used actual data for the split between char and volatile nitrogen. The bituminous coal predictions would be improved if data were available on the nitrogen content of the chars.

These limiting-case simulations show the importance of distinguishing between volatile and char nitrogen. The improved $\mathrm{NO}_{\mathrm{x}}$ model will provide more confidence in the NO predictions obtained for the full-scale design of the HITAF. It should be noted, however, that the added progress variable, which was implemented to track volatile products from the coal, requires additional computational overhead. The distinction also requires that the nitrogen split between volatiles and char be known.

\section{Slag-Layer Thickness Model}

The transfer of heat in the radiant section to the working fluid prior to entering the turbine is the driving force behind the design of the HITAF. As this heat transfer is limited by conduction of the incident flux through the radiant panel walls, it important to fully understand the extent of ash 
deposition during normal operation. The current design calls for fully flowing walls for the radiant panel section to minimize the ash-layer resistance; therefore, the temperature of the combustion gases entering the radiant zone must be high enough to promote flowing of the deposited material. To accurately predict the impact of slag flowing or freezing on the efficiency of the radiant heat exchanger, the detailed model for slag formation, described in the Quarterly Report for the Period January 1, 1993 - March 31, 1993, was implemented in the comprehensive coal combustion code. The algorithm was modified slightly to allow for its implementation and the resulting computer model was utilized to reanalyze previous design calculations of the HITAF obtained using specificd thicknesses for ash layers.

The current design of the HITAF specifies an initial adiabatic section of 25 meters prior to entering the radiant heat transfer section where the heat exchanger tubes are located. The use of the long axial flame for $\mathrm{NO}_{\mathrm{x}}$ control provides a very fuel rich central core which persists for a long residence time within the HITAF. As a consequence of this delayed mixing, the temperature of combustion gases does not rise rapidly enough to prevent the formation of frozen slag-layer deposits which can add significantly to the overall heat transfer resistance through the radiant panel walls. An initial adiabatic length of 25 meters provides enough residence time to allow for both the fuel-rich devolatilization of fuel-nitrogen species, and the attainment of a high enough combustion gas temperature to prevent the formation of a frozen slag layer.

To illustrate the ability of the computer to predict flowing and frozen ash layer thicknesses, two different HITAF design calculations will be presented here. The current design of $25 \mathrm{~m}$ of adiabatic length combined with $16.5 \mathrm{~m}$ of heat exchanger tube length (total $\sim 42 \mathrm{~m}$ ) will be compared with a calculation using only 15 meters of adiabatic length. The predictions of ash layer thicknesses for the case of $25 \mathrm{~m}$ of adiabatic length are shown in Figure 3, with the corresponding temperature predictions shown in Figure 4. Note that for this case, there is very little dry ash layer predicted in the radiant heat exchanger zone, less than $1 \mathrm{~mm}$, and it rapidly decays thereby minimizing heat transfer resistance due to the deposition of ash. The temperature plot, Figure 4, also demonstrates the avoidance of the dry ash layer formation. The fireside wall temperature in the radiant zone $(25-42 \mathrm{~m})$ is consistently above $1498 \mathrm{~K}$, which is the critical viscosity temperature for the design coal, Illinois \#6.

The case of $15 \mathrm{~m}$ of adiabatic length is illustrated in Figures 5 and 6 . The predictions for ash-layer thickness for this case, shown in Figure 5 as a log plot for clarity, clearly indicate the formation of a frozen layer of ash of up to $14 \mathrm{~cm}$ in thickness in the initial region of the radiant zone, with the thickness of the dry layer slowly decaying as the combustion gases heat up (compare Figure 6). The flowing slag layer thickness is essentially non-existent initially and then forms a layer of $1-2 \mathrm{~mm}$ in thickness. The temperature plots of Figure 6 correspond to the behavior shown in Figure 5 where it is clear that the fireside wall temperature is at or below the critical viscosity temperature in the initial regions of the radiant zone. It should also be noted that for this case, the overall length of the combustor required for achieving the current design heat exchanger outlet temperature of $1200 \mathrm{~K}$ is less than that of the $25 \mathrm{~m}$ 


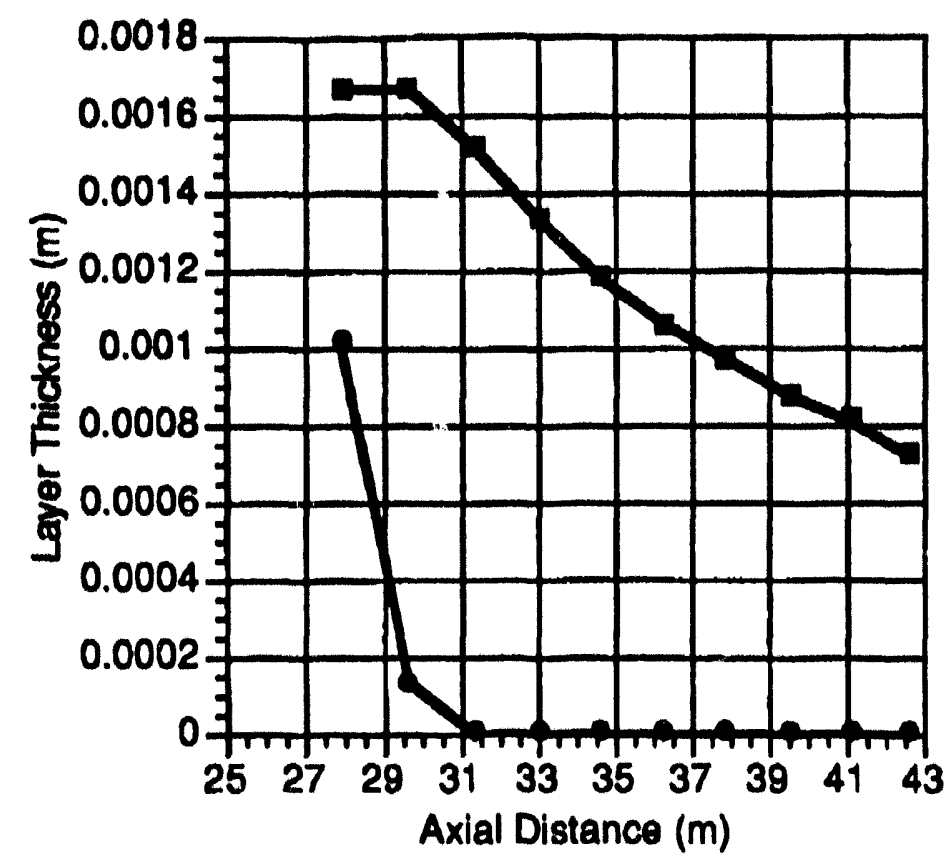

$\rightarrow$ Flowing Layer

Frozen Layer

Figure 3. Model predictions of ash-thicknesses for the case of $25 \mathrm{~m}$ of adiabatic length.

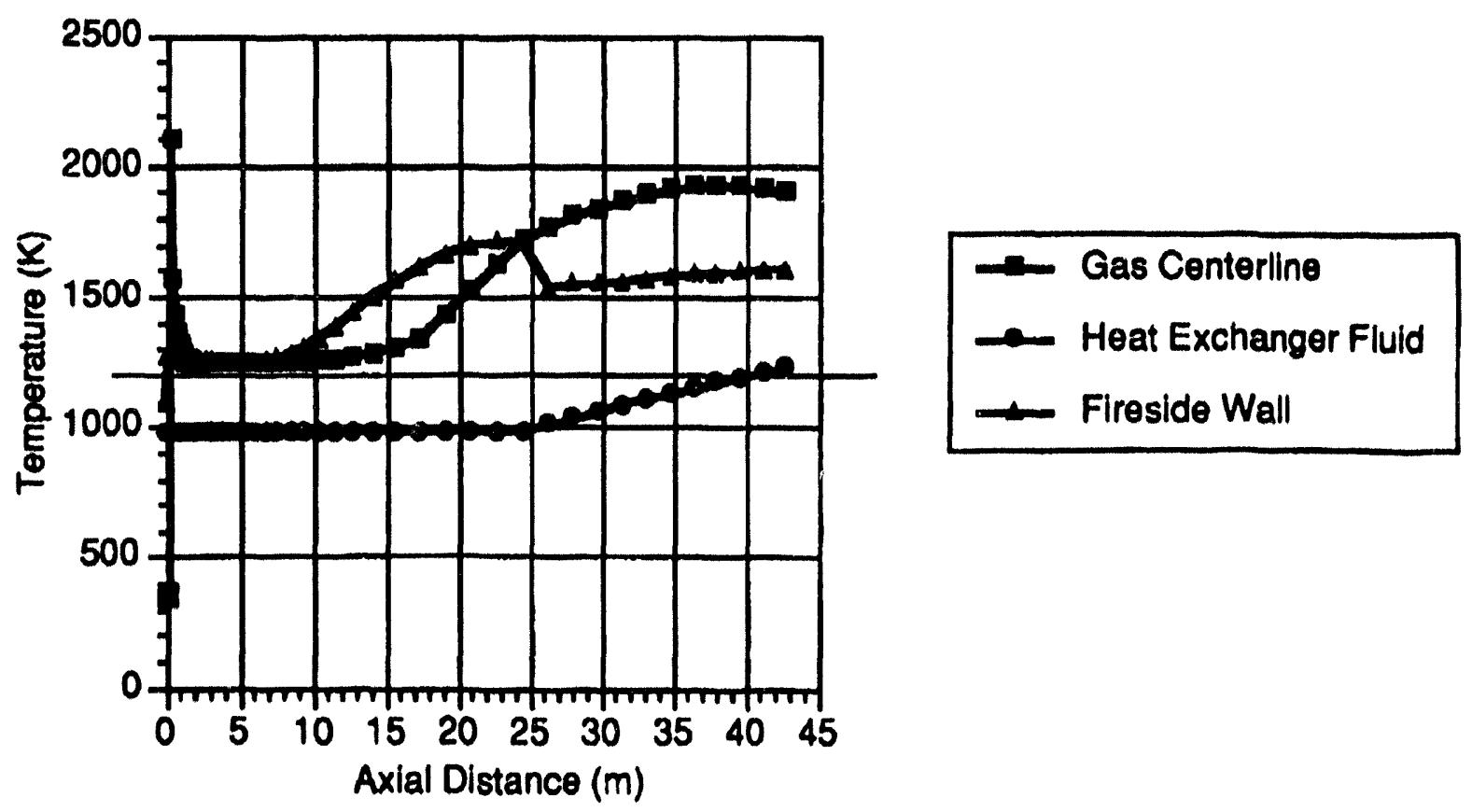

Figure 4.. Temperature predictions for the case of $25 \mathrm{~m}$ of adiabatic length.

case; however, the length of the heat exchanger tubes in this case is considerably greater $(23 \mathrm{~m}$ [extrapolated] vs. $16 \mathrm{~m}$ ). The additional length of heat exchanger tubes produces a higher pressure drop which results in a higher load for the compressor, thus reducing the efficiency of the cycle. 

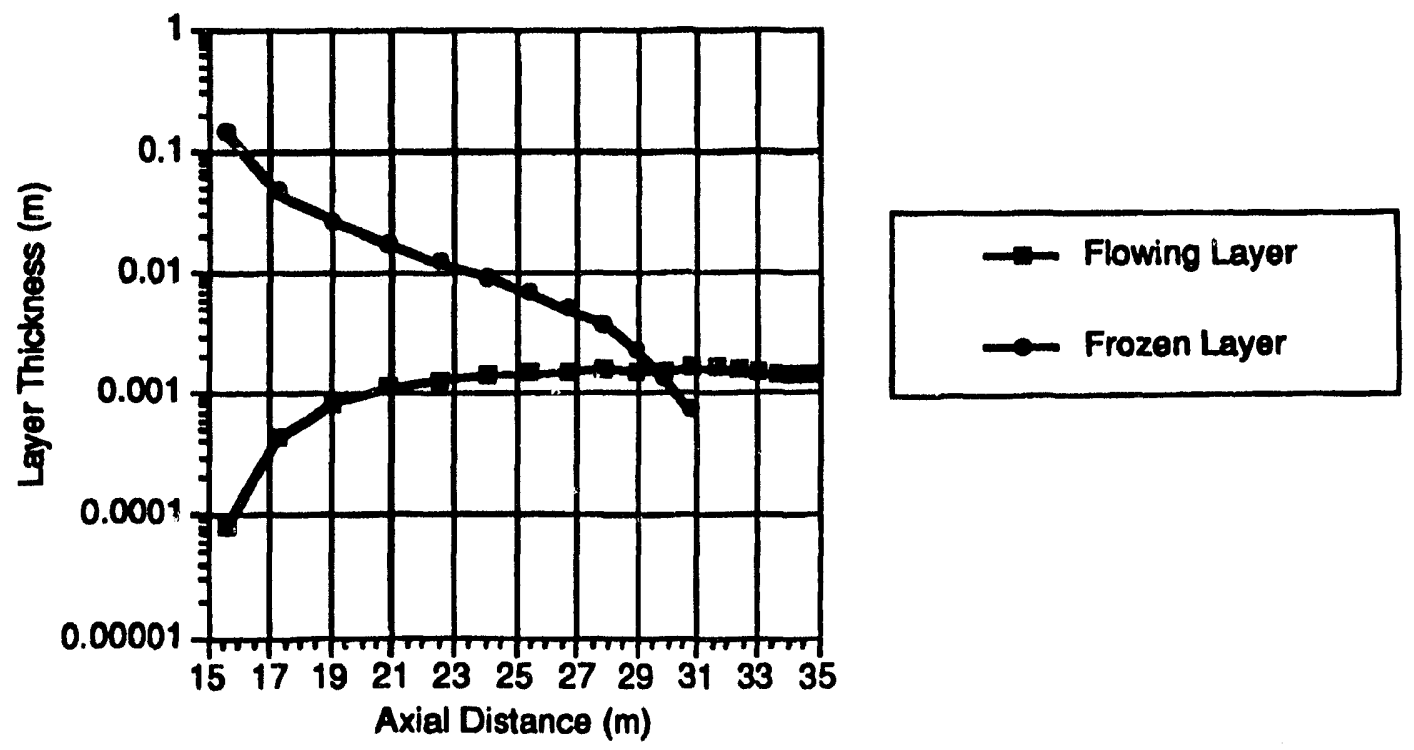

Figure 5. Model predictions of ash-thicknesses for the case of $15 \mathrm{~m}$ of adiabatic length.

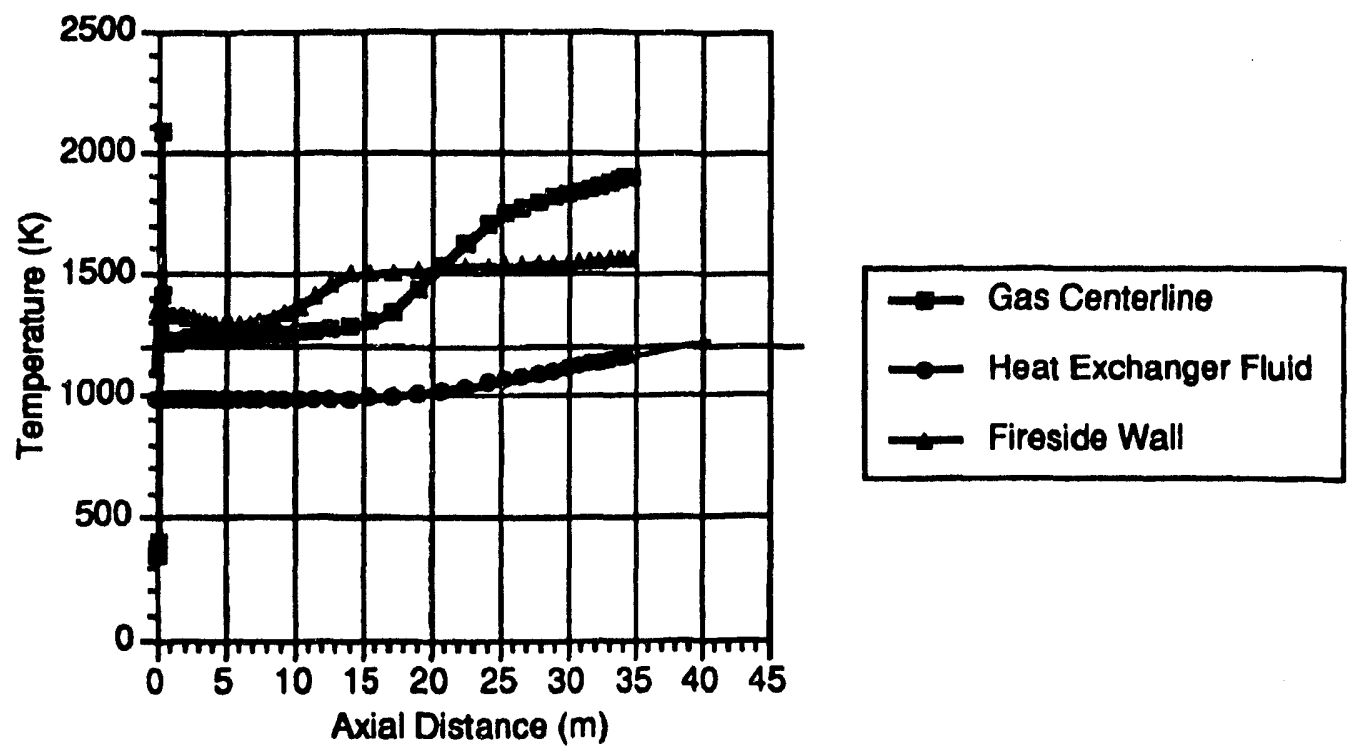

Figure 6. Temperature predictions for the case of $15 \mathrm{~m}$ of adiabatic length. 


\section{HITAF CONVECTIVE AIR HEATER}

Preliminary concept screening for various convective air heater configurations has been completed. A finned-tube-sheet design (Fig. 7) has been selected for further study. The tube sheets are spaced 4" apart and consist of 1" I.D. cylindrical tubes spaced 3" on center in the baseline design. Four variants of this design are to be evaluated with the objective of minimizing ash deposition on the surfaces of the heat exchanger. The four designs are:

1) In-line cylindrical tubes (Fig. 8)

2) Staggered cylindrical tubes (Fig.9)

3) In-line, 5:1 aspect ratio ellipsoidal tubes (Fig. 10)

4)Staggered, 5:1 aspect ratio ellipsoidal tubes (Fig. 11)

Note that the elliptical tubes have been sized to provide the same cross-sectional area as the cylindrical tubes. The hot gas inlet conditions are: $p=1 \mathrm{~atm}, \mathrm{~T}=1800^{\circ} \mathrm{F}$ and $\mathrm{V}=54.5 \mathrm{f} \hat{\mathrm{t}} / \mathrm{s}$. Air temperatures inside the tubes are $1300^{\circ} \mathrm{F}$ and $735^{\circ} \mathrm{F}$ at the hot gas inlet and outlet of the heat exchanger, respectively. Wall temperatures are estimated to be $1445^{\circ} \mathrm{F}$ and $885^{\circ} \mathrm{F}$ at the inlet and outlet, respectively. Two cases for ash particle mass loading are given in Table 2.

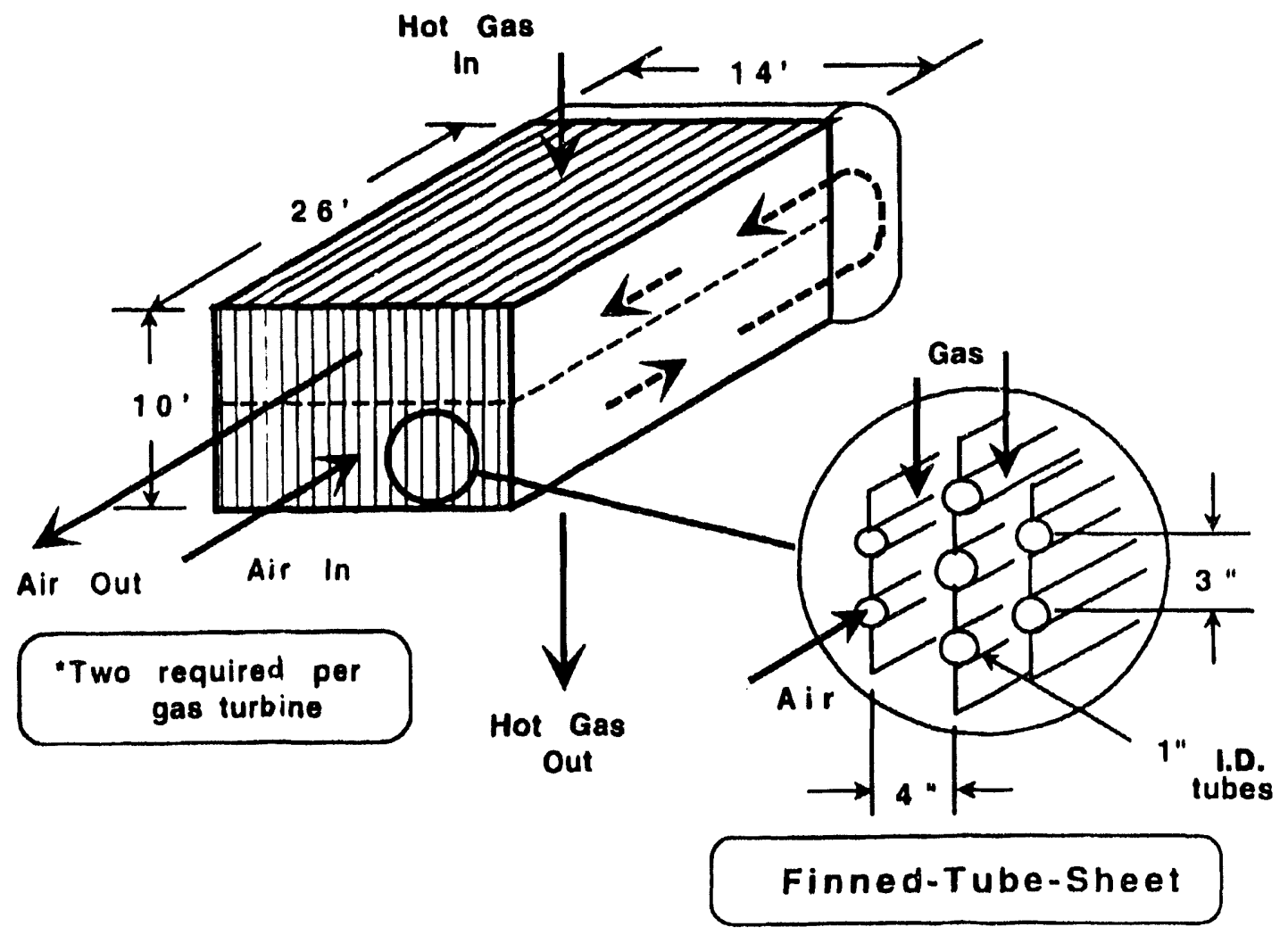

Figure 7. Convective air heater. 

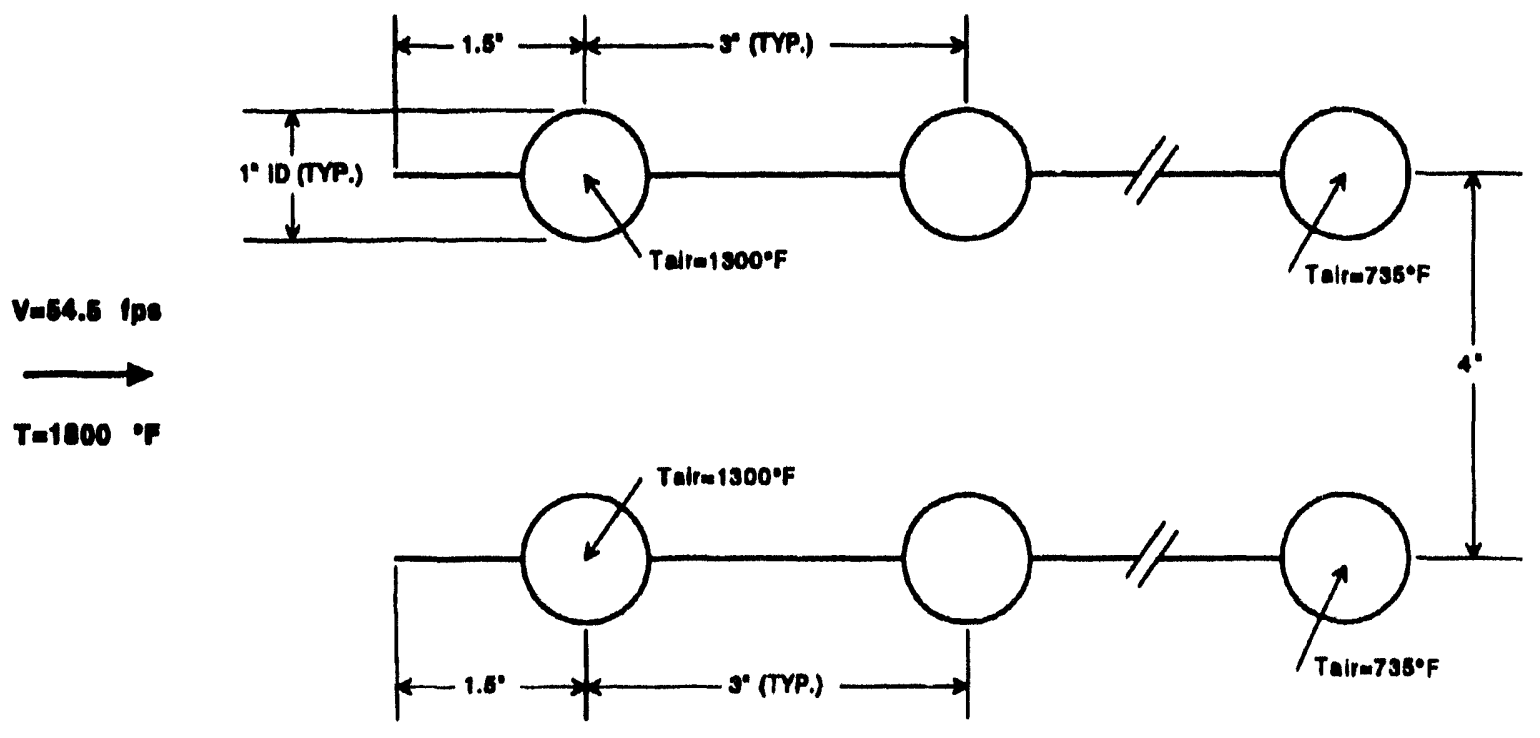

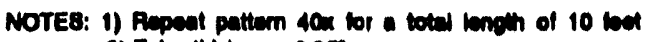
2) Tube thicionen $0.20^{\circ}$

3) Fin (or mb) thichnese $0.80^{\circ}$

Figure 8. In-line tube array.

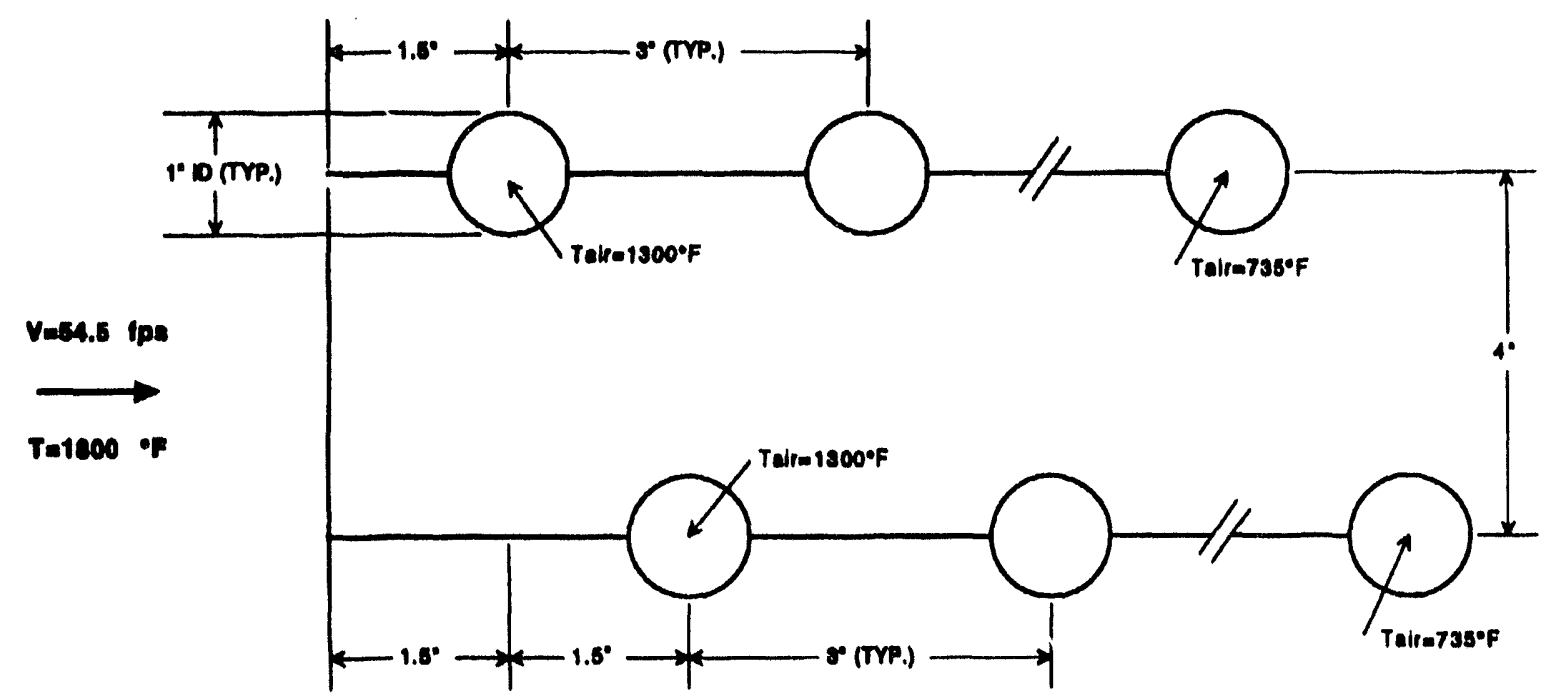

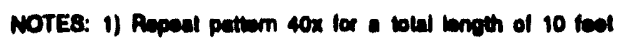

a) Tuts thininieses 0.26"

9) Fin (or wob) thelenese $0.60^{\circ}$

Figure 9. Staggered tube array. 


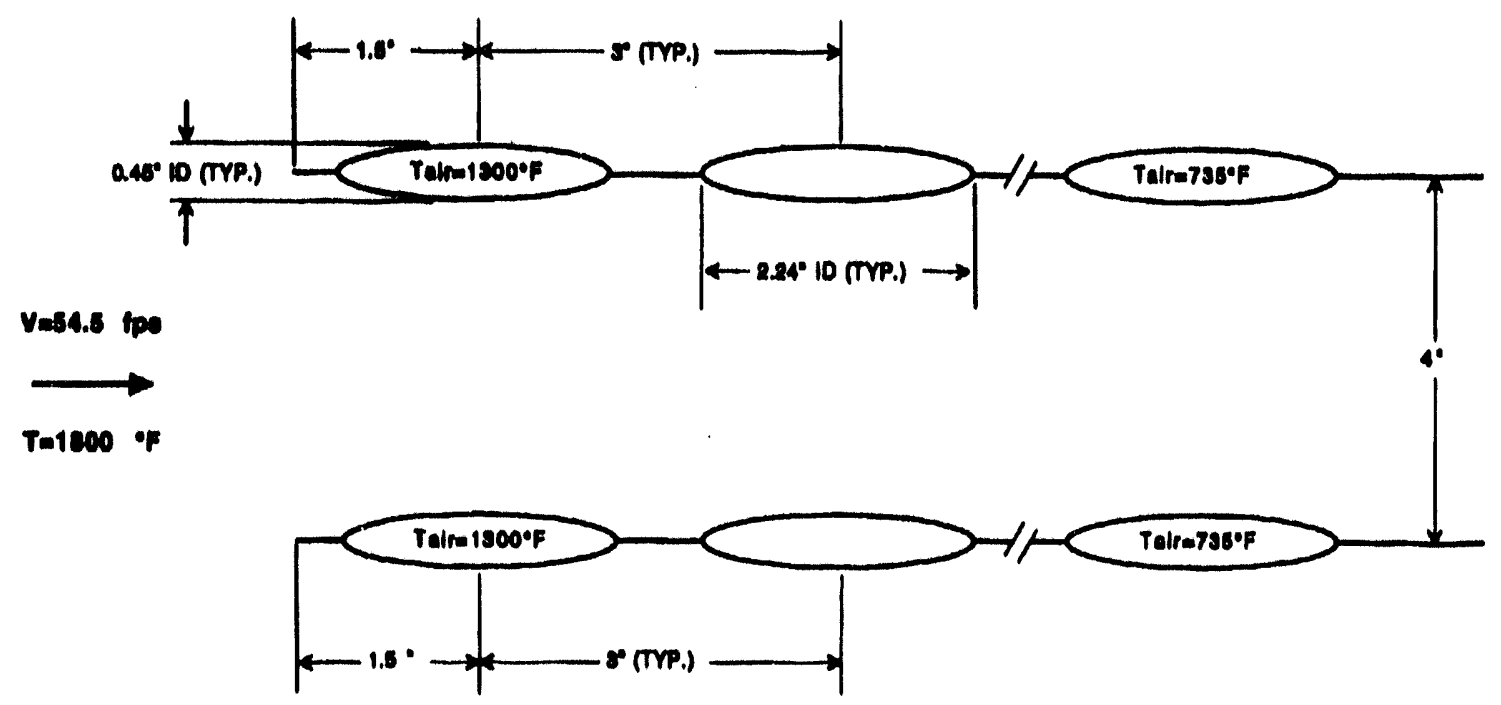

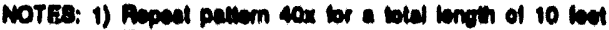

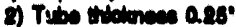

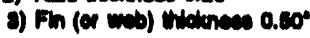

Figure 10. In-line tube array - 5:1 aspect ratio ellipsoidal tubes.

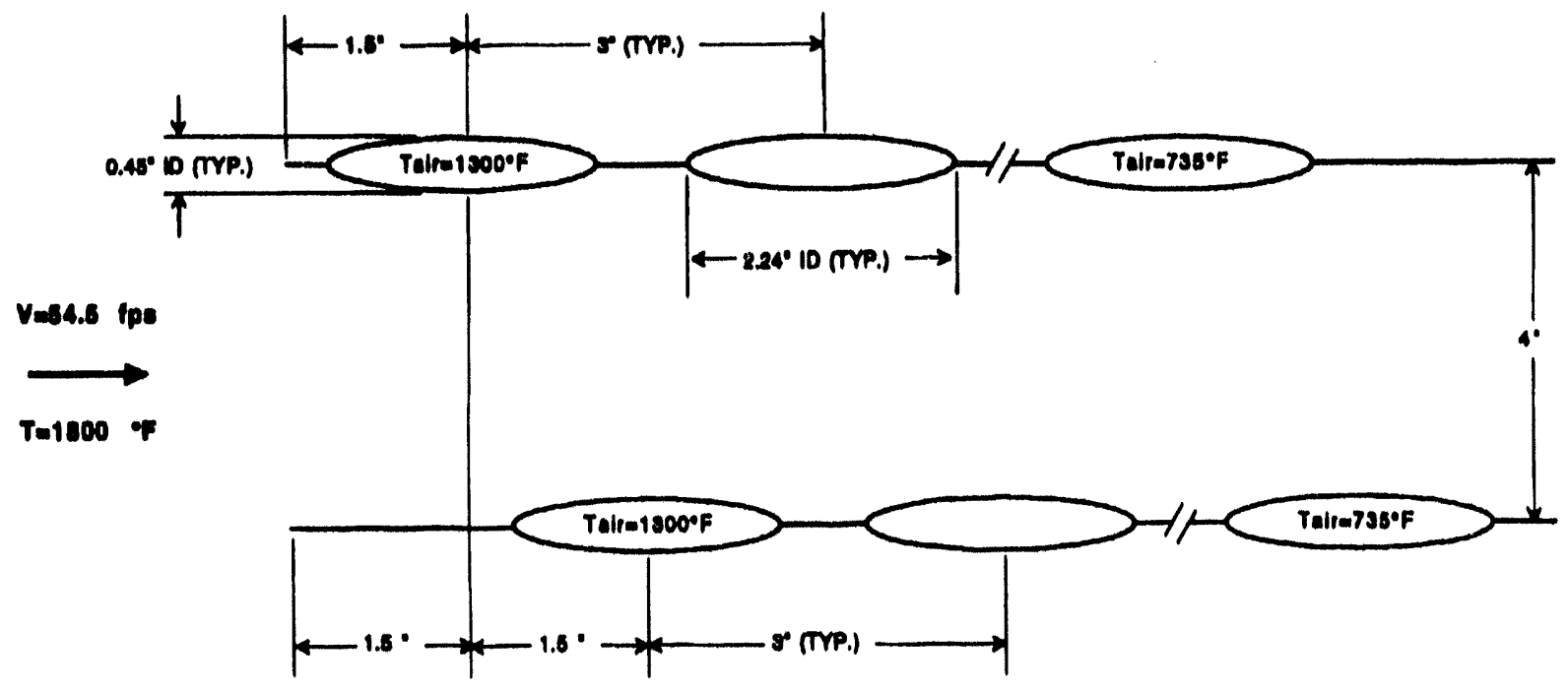

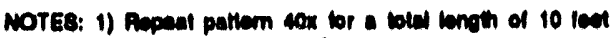
2) Tubs tratenem $0.25^{\circ}$

3) Fh (or wa) thidenceos $0.60^{\circ}$

Figure 11. Staggered tube array - 5:1 aspect ratio ellipsoidal tubes. 
Table 2. Ash particle size distribution at inlet of HITAF convective air heater.

\begin{tabular}{|c|c|c|}
\hline & Ash Loading $\left[\mathrm{kg} / \mathbf{m}^{3}\right]$ & Ash Loading $\left[\mathrm{kg} / \mathbf{m}^{3}\right]$ \\
\hline Particle Size Range $(\mu \mathrm{m})$ & $\begin{array}{c}\text { Case 1 } \\
\text { (before Slag Screen) }\end{array}$ & $\begin{array}{c}\text { Case 2 } \\
\text { (after Slag Screen) }\end{array}$ \\
\hline $1-2.5$ & $7.71 \mathrm{E}-06$ & $9.31 \mathrm{E}-06$ \\
\hline $2.5-5$ & $8.96 \mathrm{E}-05$ & $1.08 \mathrm{E}-04$ \\
\hline $5-10$ & $2.40 \mathrm{E}-04$ & $2.60 \mathrm{E}-04$ \\
\hline $10-20$ & $3.69 \mathrm{E}-04$ & $1.78 \mathrm{E}-04$ \\
\hline $20-40$ & $3.08 \mathrm{E}-04$ & 0 \\
\hline $40-80$ & $1.38 \mathrm{E}-04$ & 0 \\
\hline TOTAL & $1.15 \mathrm{E}-03$ & $5.55 \mathrm{E}-04$ \\
\hline
\end{tabular}

CFD Analysis of Heat Exchanger Designs

Computational fluid dynamics (CFD) is being used to analyze the particle-laden flow within the heat exchanger to provide estimatus of the rate of deposition of particulates on the heat exchanger surfaces. The code being used is FLUENT, a commercially developed code that solves the governing conservation equations in body-fitted coordinates using a collocated grid method; that is, all flow variables, including the Cartesian velocity components, are siored at the same grid locations.

The code was used to predict the flow distribution for heat exchanger designs that incorporate tubes of either circular or elliptical cross-sectional area arranged in rows in which the tubes are aligned or staggered with respect to each other. The ratio of major to minor axis length was five for the elliptical tubes. Generally, the computational domain consisted of three tubes in each row, although a case was also run in which five tubes were analyzed to determine if the number of tubes affects the particulate distribution rate. The effects of different values of free stream turbulence intensity and tube wall temperature were also examined.

All cases were run with an inlet velocity of $54.5 \mathrm{ft} / \mathrm{s}$ and an inlet temperature of $1800 \mathrm{~F}$. The cases are listed in Table 3.

Table 3. Geometry and flow conditions.

\begin{tabular}{|c|c|c|c|c|c|}
\hline Case & $\begin{array}{l}\text { Cross- } \\
\text { section }\end{array}$ & Number & Arrangement & $\begin{array}{l}\text { Turb. Int. } \\
\text { percent }\end{array}$ & $\begin{array}{l}T_{w} \\
{ }^{\circ} \mathbf{F}\end{array}$ \\
\hline HX1 & Circ. & 3 & Inline & 1 & 1445 \\
\hline HX2 & Circ. & 3 & Inline & 1 & 885 \\
\hline HX3 & Circ. & 3 & Inline & 10 & 1445 \\
\hline HX4 & Circ. & 3 & Staggered & 10 & 1445 \\
\hline HX5 & Circ. & 5 & Inline & 10 & 1445 \\
\hline HX6 & Ellip. & 3 & Inline & 10 & 1445 \\
\hline HX7 & Ellip. & 3 & Staggered & 10 & 1445 \\
\hline
\end{tabular}

Initial estimates of particulate deposition rates were obtained by assigning a spatially uniform distribution of particles at the inlet plane; the particle size distribution was representative of 
distributions with or without slag screens. FLUENT provides the capability to compute particle trajectories either deterministically or stochastically. In the deterministic model, particle trajectories are computed using the mean flow field only. In the stochastic model, the trajectories are calculated with the effects of random fluctuations of the gas due to turbulence included. Thus, it can be expected that the trajectories of larger particles are determined essentially by inertial effects (that is, they can be computed essentially from the mean flow field) while the trajectories for smaller particles will be influenced by turbulent fluctuations.

Generally, it was determined that the results were insensitive to the tube temperature assumed; the remaining cases were run using the higher temperature, representative of the tubes in the upstream section of the heat exchanger.

Increase turibulent intensity was found to increase the rate at which smaller particles are trapped by the surface due to turbulent diffusion. The higher value of turbulent intensity (ten percent) was used for the remaining cases. This value is more representative of the levels encountered in industrial equipment.

Stream lines for cases HX3, HX4, HX6 and HX7 are presented in Figs. 12-15, respectively. For the inline arrangement, it was necessary to compute the flow in only one-half of the passage between tube banks. For the circular tubes, the recirculation zone on the downstream side of each tube is evident (Figs. 12 and 13). Essentially no recirculation zones are predicted to occur in the passages using the more aerodynamic elliptical tubes.

Trajectories for some of the larger (30 micron) particles are shown in Figs. 16 and 17 for the circular and elliptical tubes, respectively. For these larger particles, the effects of turbulent fluctuations are relatively small although these effects cannot be ignored completely, as is evident by the fact that some of the trajectories appear to cross at downstream locations. For the circular tube case (Fig. 16), particles with initial positions essentially below the top of the tubes impinge on the upstream side of the first tube; the outer particles bypass the tube row completely.

It is found in other simulations involving a larger number of particles that a few of the particles in the outer region may enter the recirculation zone. One implication of these results is that it may be beneficial to replace the first tube with a sacrificial rod that can be used to remove the larger particles that are otherwise likely to impinge on the heat exchanger.

Note that similar results were obtained for case HX5 with five tubes. Obviously, deposition of large particles becomes unimportant farther downstream as particles are removed by the upstream tubes.

For the elliptical tube case with 30 micron particles (Fig. 17), it is seen that the first tube is much less effective in removing particles. It is anticipated that several of the tubes in this case will accumulate deposits of larger particles. 


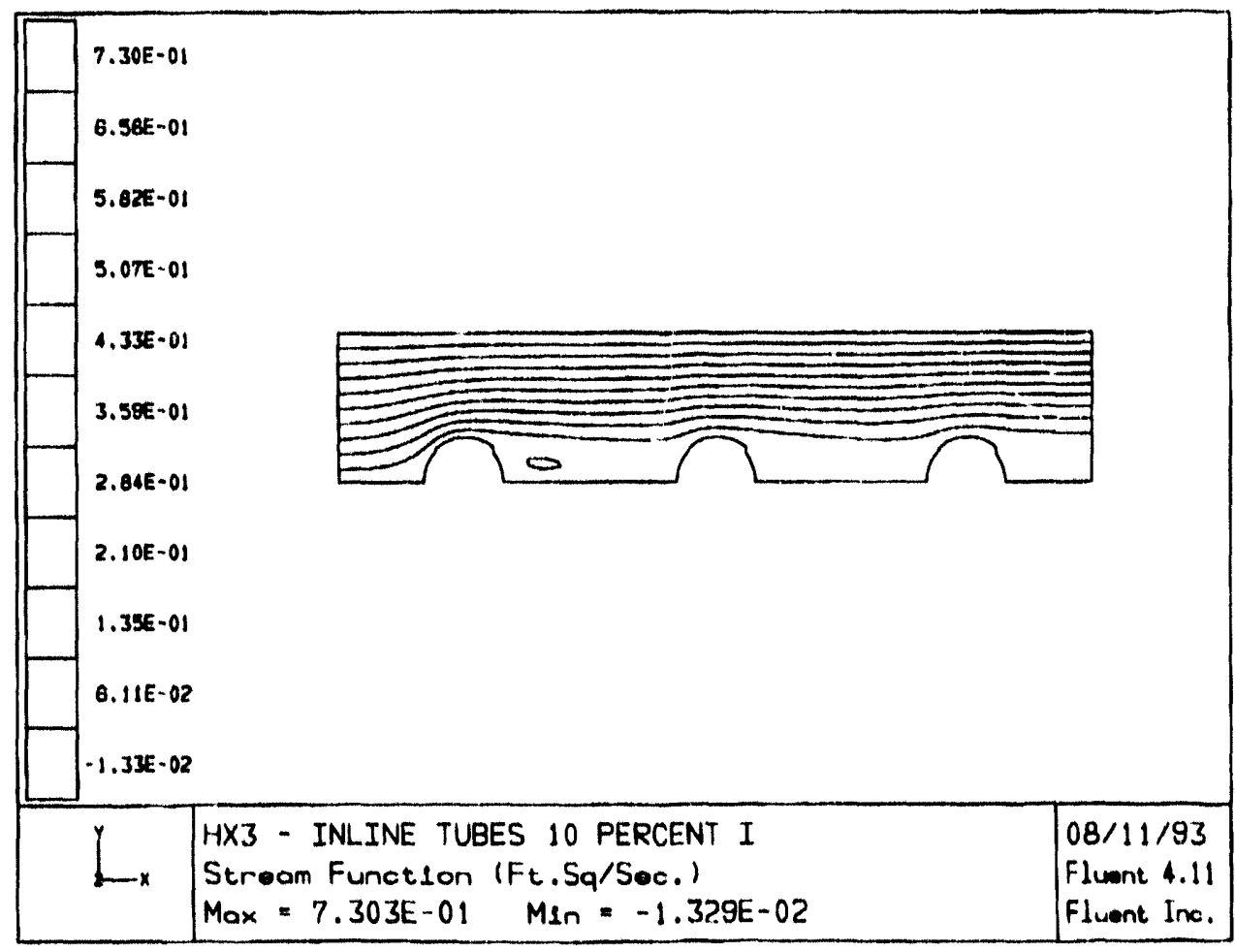

Figure 12. In-line tubes 10 percent I.

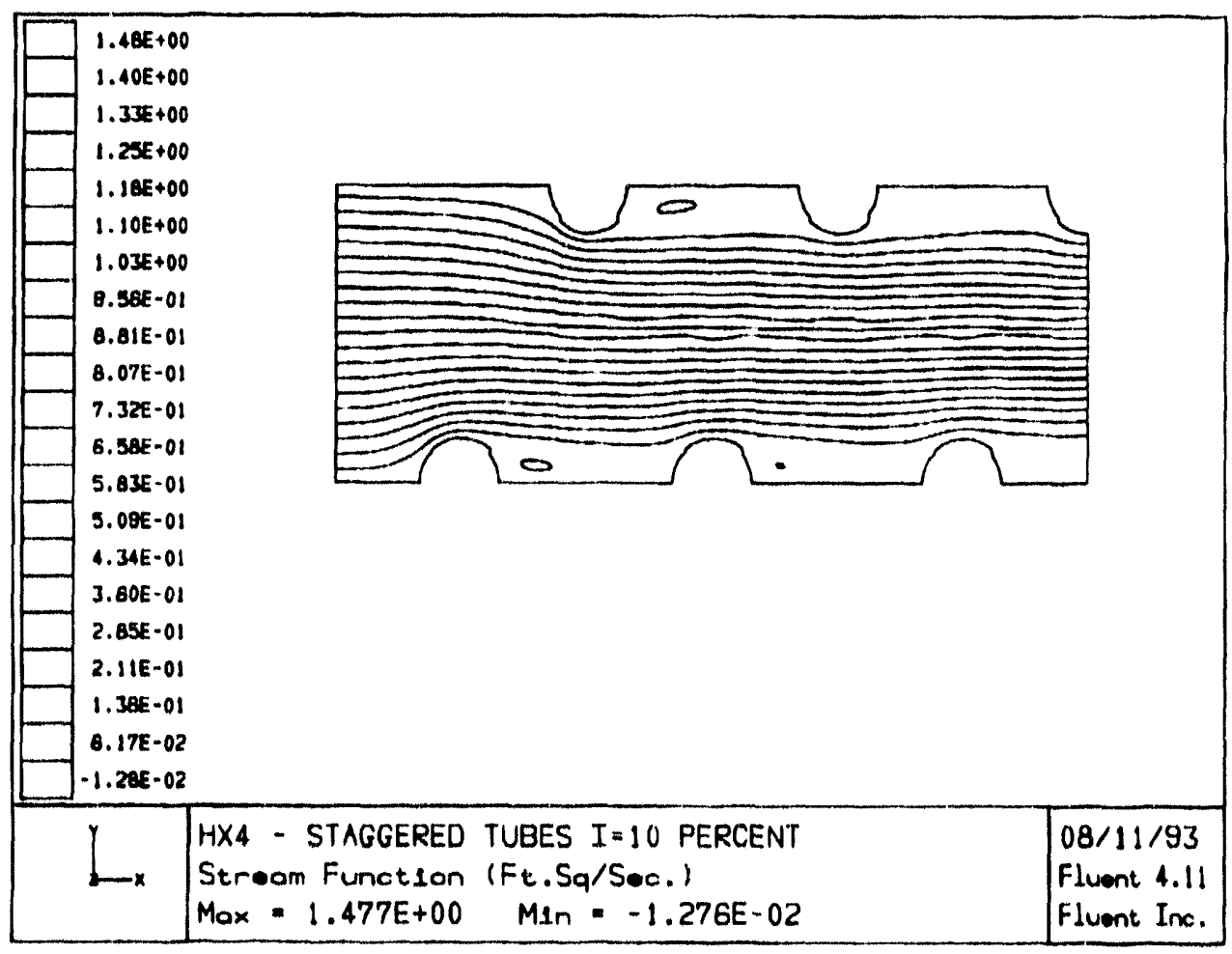

Figure 13. Staggered tubes $I=10$ percent. 


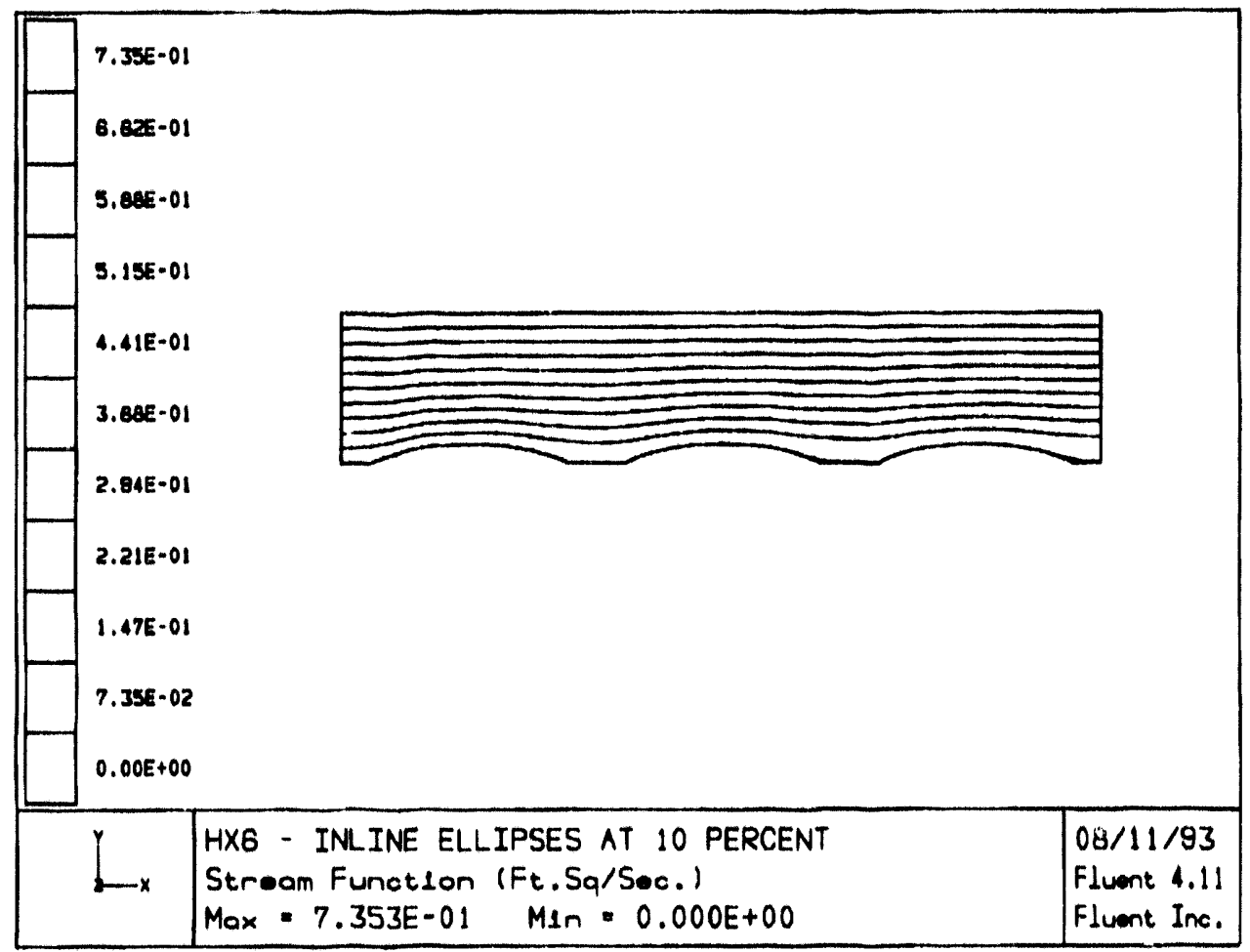

Figure 14. In-line ellipses at 10 percent.

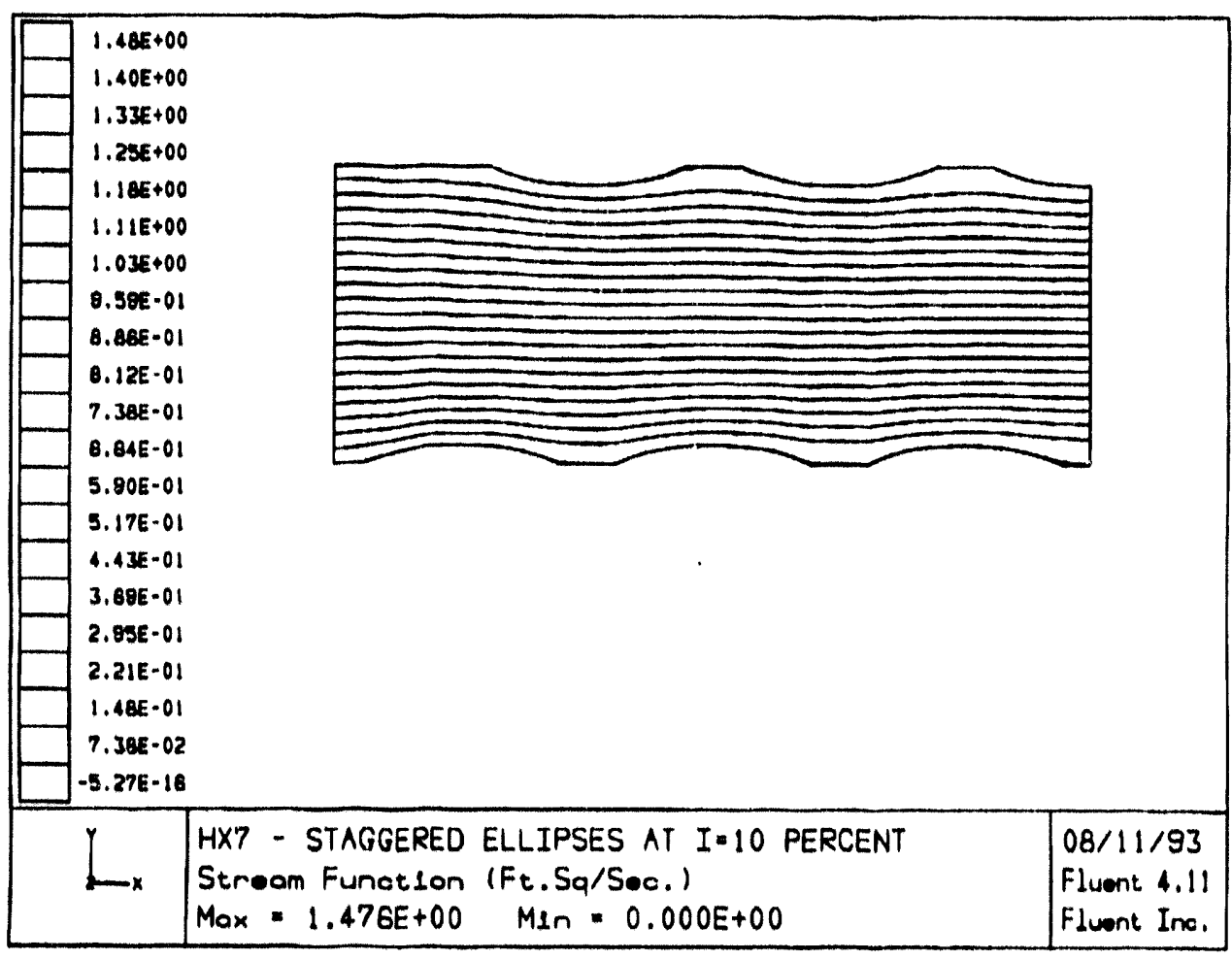

Figure 15. Staggered ellipses at $I=10$ percent. 


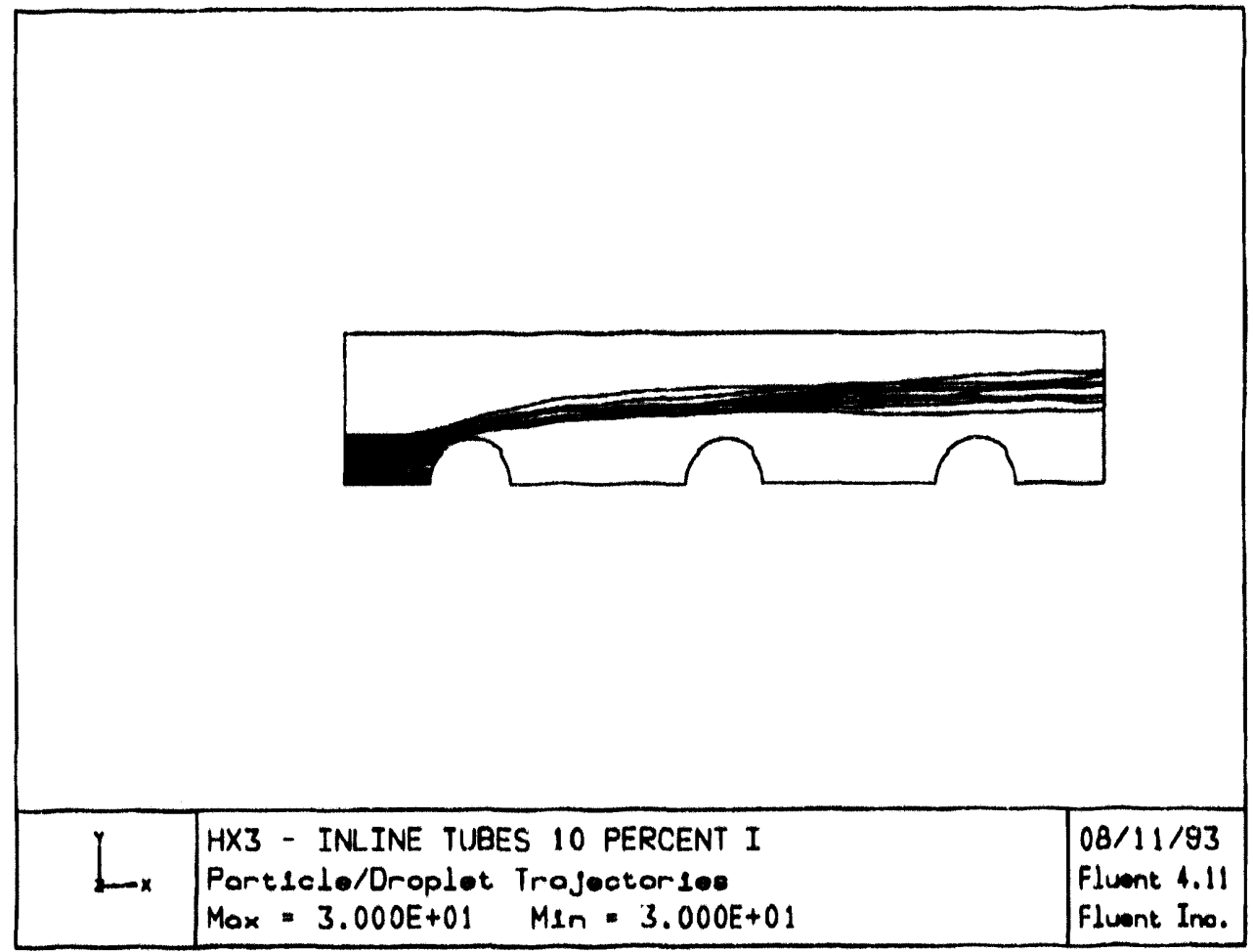

Figure 16. In-line tubes 10 percent $I$.

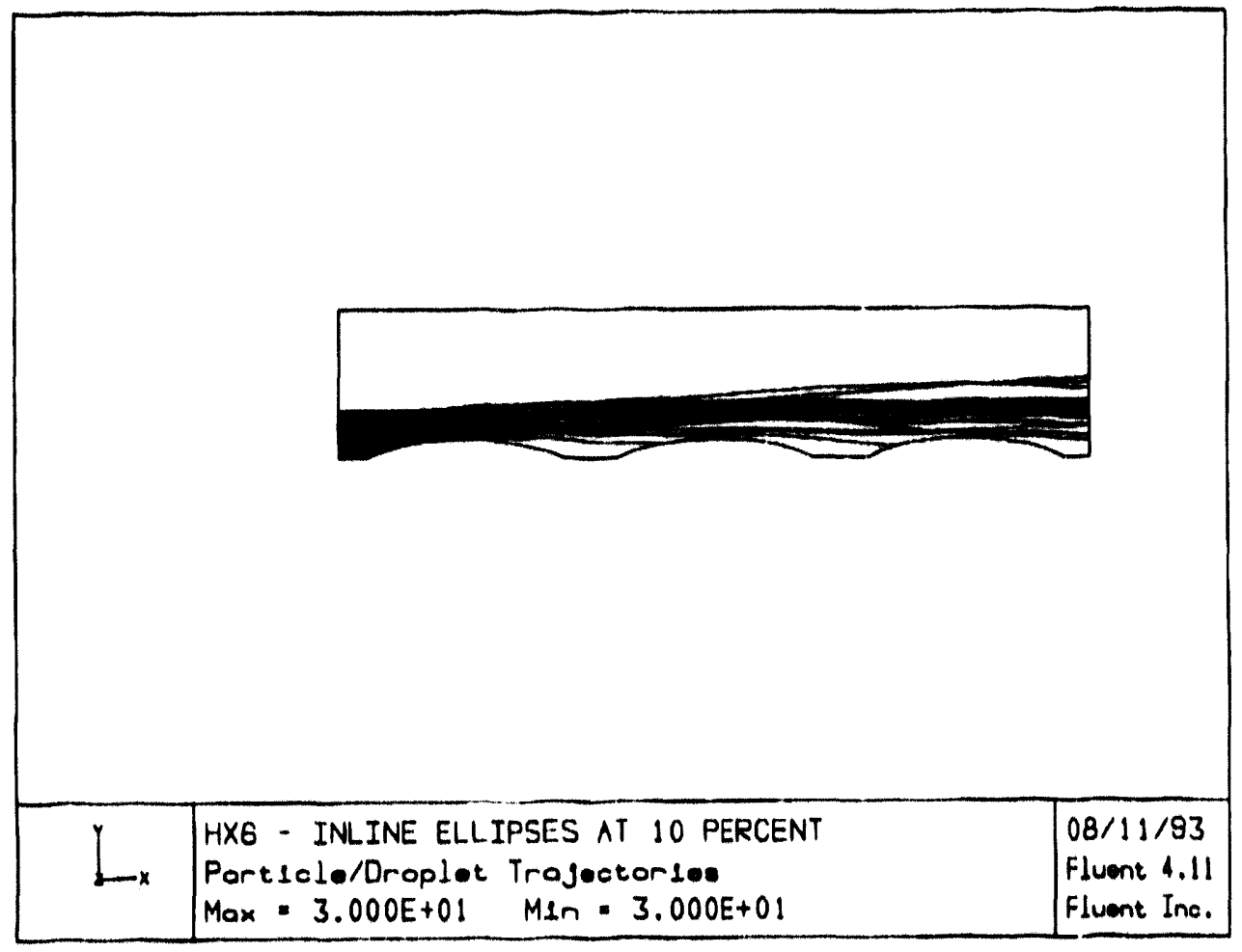

Figure 17. In-line ellipses at 10 percent. 
Results using the smallest particles considered (1.25 microns) are presented in Figs. 18 and 19 for the circular tube and elliptical tube cases, respectively. Particle dispersion due to turbulent diffusion is evident here. For the circular tube case (Fig. 18), particles are seen to impinge on the surface between tubes. Preliminary results using a much greater number of realizations suggest that small particles will impinge more or less uniformly on the entire surface in the upstream section of the heat exchanger. For the elliptical tube case (Fig. 19), the same situation is likely to occur.

Essentially similar results were obtained for the staggered tube cases. The tube banks are far enough apart that the interaction of the particles with either surface occurs independently.

During the next reporting period, more detailed particle dispersion results will be obtained and will be used to estimate deposition rates. The most favorable design will be selected for further analysis. Conjugate heat transfer calculations will be performed to evaluate hep! transfer performance and to determine material temperatures for input to a finite element stress analysis code.

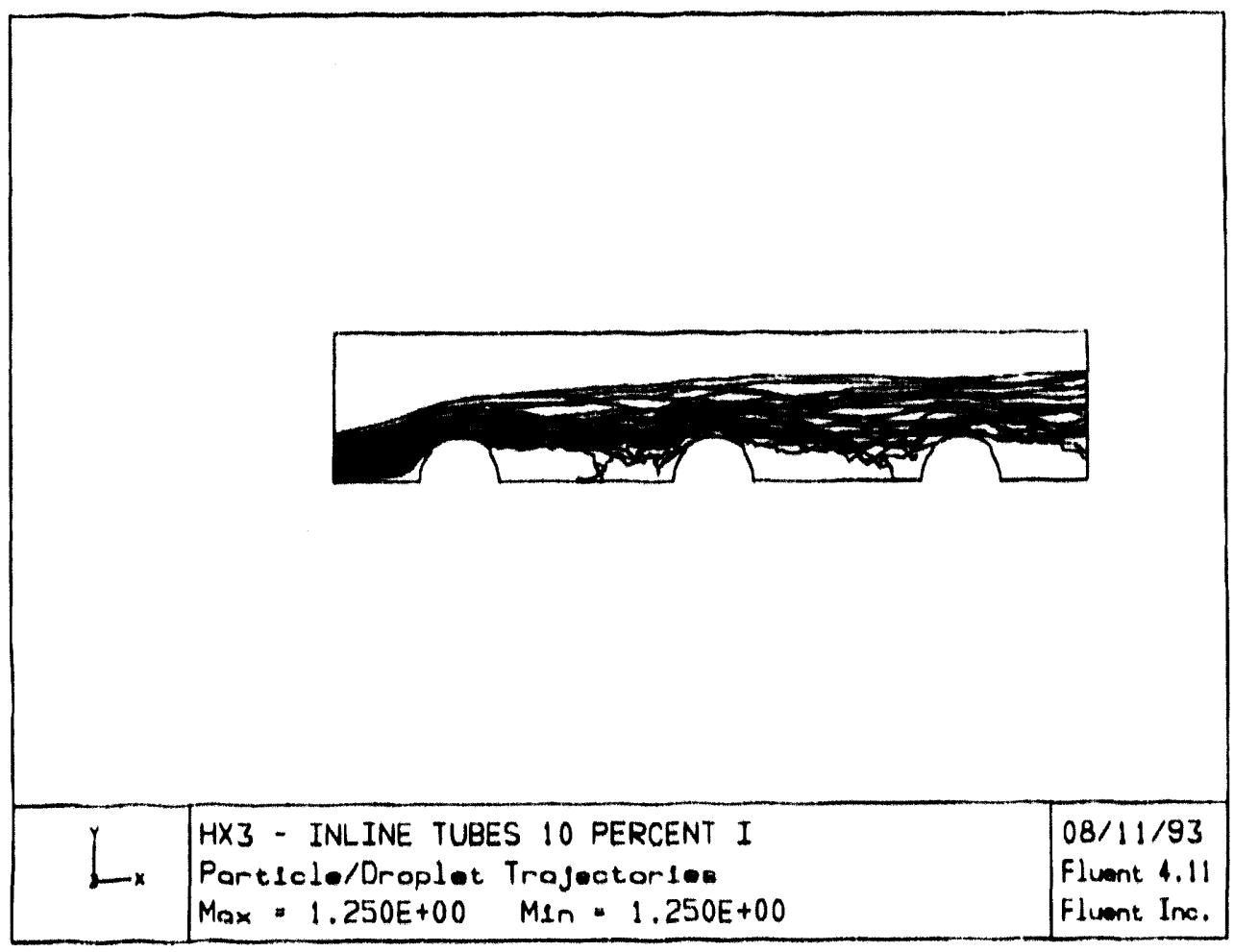

Figure 18. In-line tubes 10 percent I. 


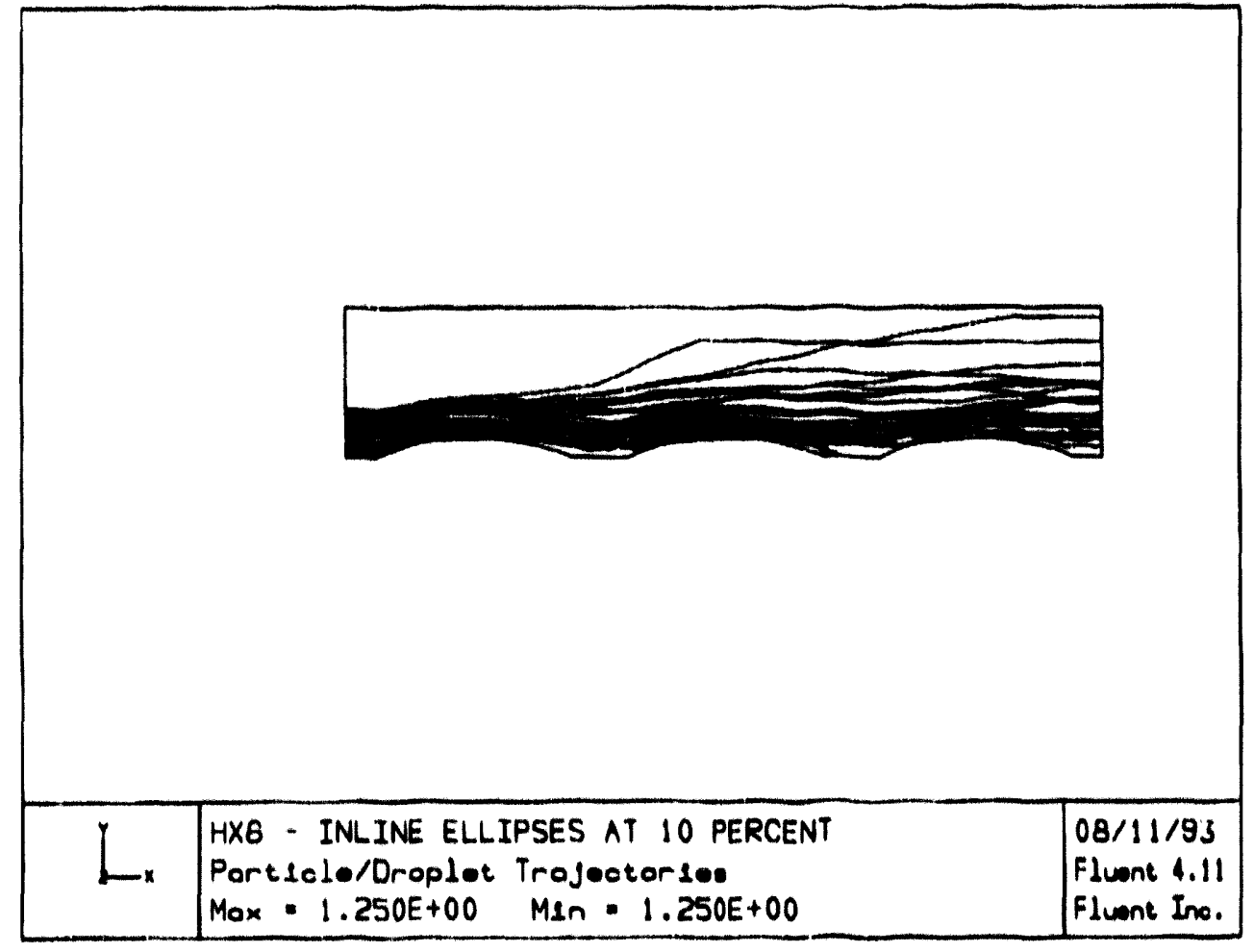

Figure 19. In-line ellipses at 10 percent. 


\section{AIR HEATER MATERIALS}

Combustor durability is a serious problem in advanced gas turbine engines. Advances in structural alloy metal temperature capability and in burner hardware cooling technology have not kept pace with the demands for more efficient (higher gas temperature) engine performance. The current materials used in the most advanced gas turbine engines are typified by the nickel base alloy Hastalloy $X$ and the cobalt base alloy Haynes 188 . These alloyw exhibit the excellent tensile strength, ductility, creep rupture, low cycle fatigue, and creep fatigue interaction behavior. They also exhibit sufficient environmental resistance as well as resistance to thermal aging and embrittlement. Most importantly they exhibit fabr:cability. They can be welded, formed and are available as sheet material at a reasonable cost. Unfortunately the nominal upper metal operating temperature for these alloys is $1600^{\circ} \mathrm{F}\left(870^{\circ} \mathrm{C}\right)$.

Wrought precipitation hardened nickel base alloys typified by Inconel 617, Incoloy 903A and Inconel 718 exhibit superior high temperature strength and imp:oved environmental resistance, but are not readily available in sheet form. However, these advantages are offset by the poor resistance to high temperature fatigue.

Inco has developed a number of inechanically alloyed oxide dispersion strengthened (ODS) superalloys of gas turbine applications. Mechanically alloying was developed for the manufacture of superalloys strengthened by both oxide dispersion and precipitation hardening. Now in its third decade, mechanically alloying provides a means for producing powder metallurgical dispersion strengthened alloys of widely varying compositions with unique sets of propertics. Components fabricated from ODS material include vane airfoils and platforms, blades, nozzles, and combustor/ augmentor assemblies. In addition diesel engine glowplugs, and heat treatment fixtures including shields, baskets, trays as well as burner hardware for coal and oil fired power stations and components used in the production of molten glass are also fabricated from ODS material.

The chemical composition and comparisons of mechanical and chemical (oxidation) propertics of the ODS alloys with the conventional alloys is shown in Table 4 and Figs. 20 to 25 to respectively. At present the only ODS material commercially available as sheet is MA 956. It is commercially available

Table 4. Alloy compositions.

\begin{tabular}{|c|c|c|c|c|c|c|c|c|c|c|c|}
\hline$A_{n}$ & mand & $m$ & ones & Amat & $n$ & $n$ & mast & $n=$ & min & and & Con \\
\hline mans & & $m$ & $\boldsymbol{m}$ & $\omega$ & $\alpha$ & & & & as & as & \\
\hline Ansing & $w$ & & 10 & 10 & & & & & 0.0 & & \\
\hline$m \pi$ & $\omega$ & & $\boldsymbol{v}$ & as & as & & & & as & and & \\
\hline$m \boldsymbol{m}$ & $w$ & & $\boldsymbol{\theta}$ & as & a & & & & $\omega$ & 200 & \\
\hline$m \pi$ & $w$ & & $\infty$ & 1 & & $\boldsymbol{M}$ & 2 & & a.s & acs & 0.01 \\
\hline MA & $w$ & & 18 & as & 21 & 1 & 2 & 2 & 1.1 & 200 & 0.01 \\
\hline
\end{tabular}


in gages down to thickness of $0.01 \mathrm{in}$. $(0.25 \mathrm{~mm})$ and widths up to $24 \mathrm{in} .(610 \mathrm{~mm})$. The alloy can be fusion welded, however weldments donot possess the inherent strength of the matrix. Procedures such as gas tungsten arc welding, electron beam welding and pulsed laser beam welding have all been used successfully on a limited scale. Vacuum diffusion bonding and diffusion brazing are extensively used. Riveting operations are commonplace.

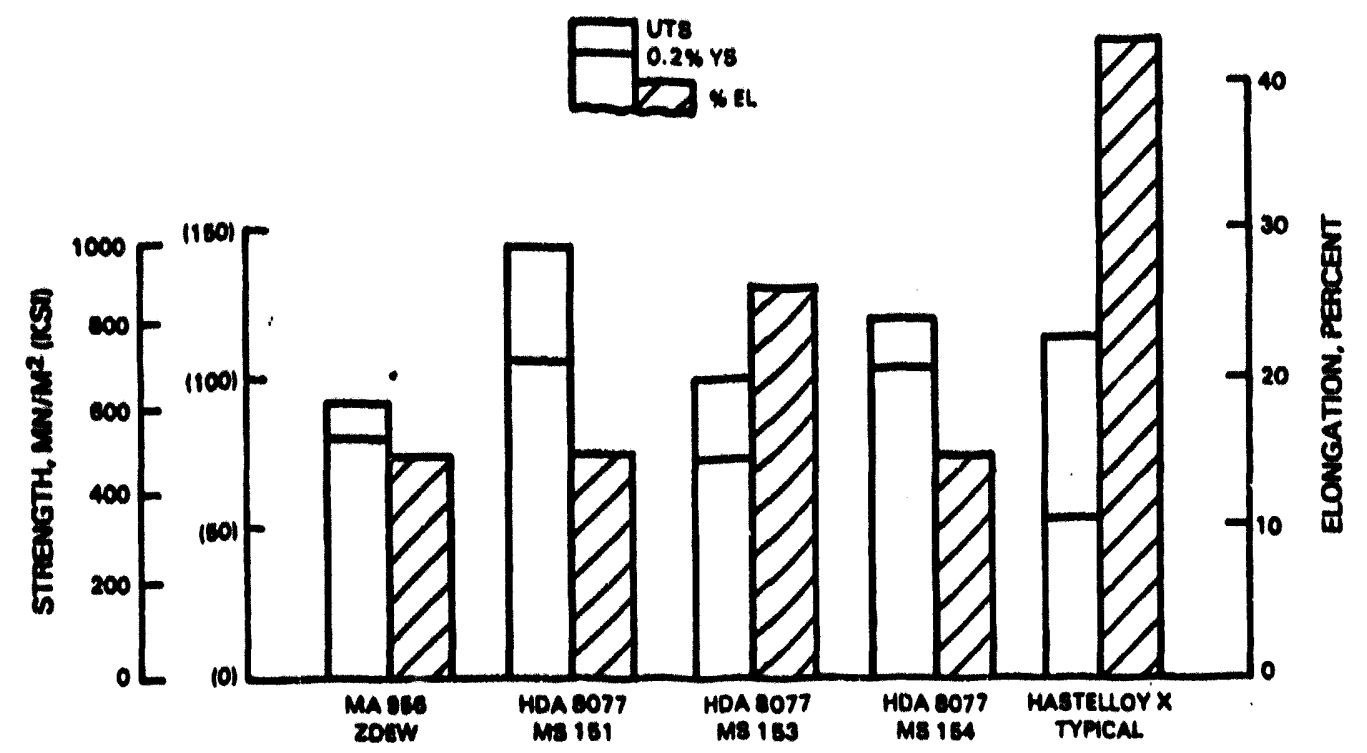

Figure 20. Room temperature tensile properties of various sheet alloys (oxide dispersion strengthened alloys tested parallel to rolling direction).

The hot spot blister thermal fatigue test is designed to produce localized distortion and thermal fatigue cracking similar to that produced by flame impingement on a combustor louver. The test procedure involves alternate localized oxy-acetylene torch heating and forced air cooling at the center of the disk. The test indicates that Hastalloy is more resistant than the ODS alloys.

The creep rupture life of the ODS alloys is significant beter than that of Hastalloy X. Assuming a Larson-Miller constant of 20 (a reasonable assumption) the difference shown translates to more than $300^{\circ} \mathrm{F}\left(167^{\circ} \mathrm{C}\right)$ creep advantage for the ODS compared to Hastalloy $X$.

Formability of sheet is frequently evaluated using Erichson cup and bend tests. In the Erichson cup test, a sample sheet is pressed into a cup form by the use of a hemispherical punch. The maximum cup depth to which the material may be pressed without cracking is taken as an indication of sheet formability. The bend test measures the minimum radius, stated in multiples of sheet thickness, over which sheet material can be bent without cracking. The experimental data indicates a superiority for Hastalloy $\mathbf{X}$.

In the mid eighties, Pratt \& Whitney examined the feasibility of employing an oxide dispersion hardened alloy to replace Hastalloy $X$. In the study it was concluded that the family of ODS materials 


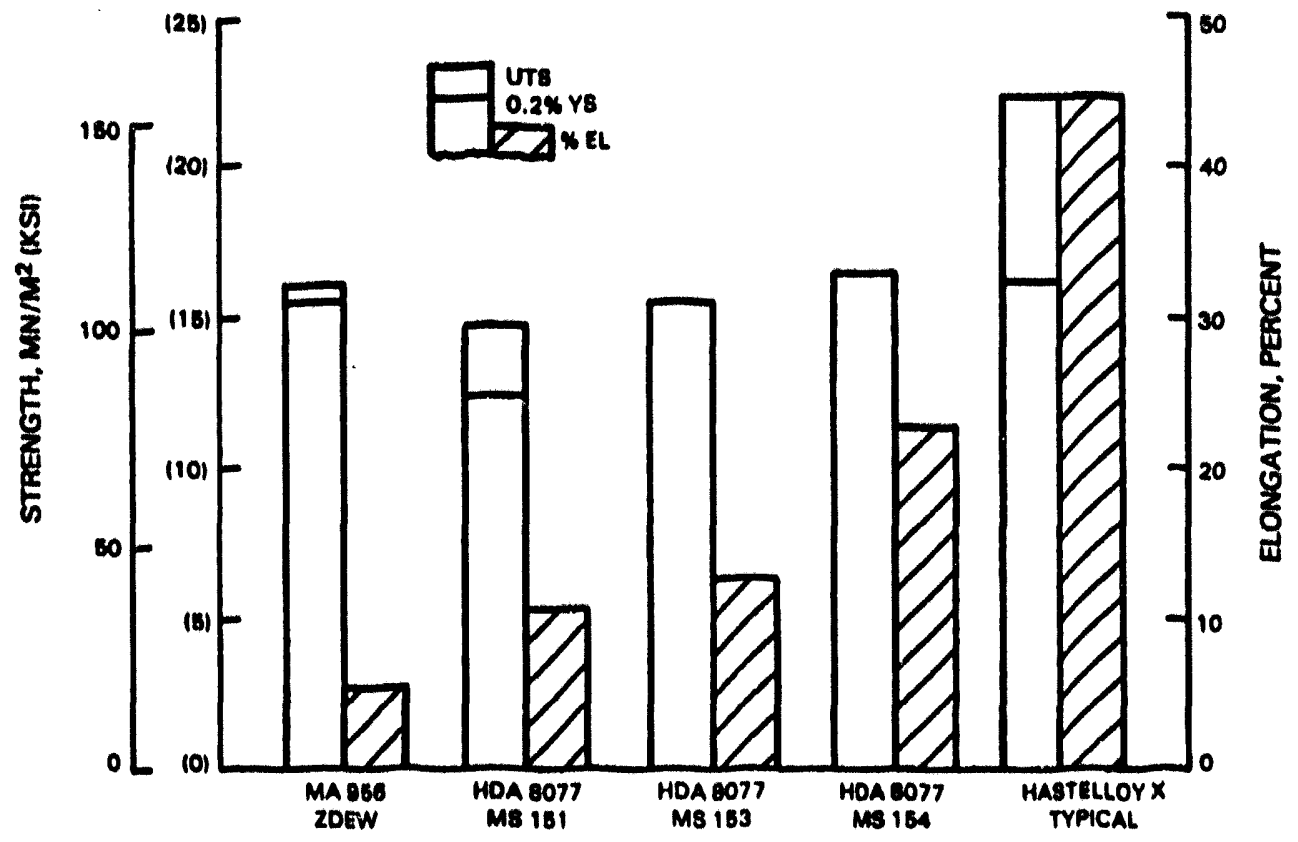

Figure $21.982^{\circ} \mathrm{C}$ tensile properties of various sheet alloys (oxide dispersion strengthened alloys tested parallel to rolling direction).

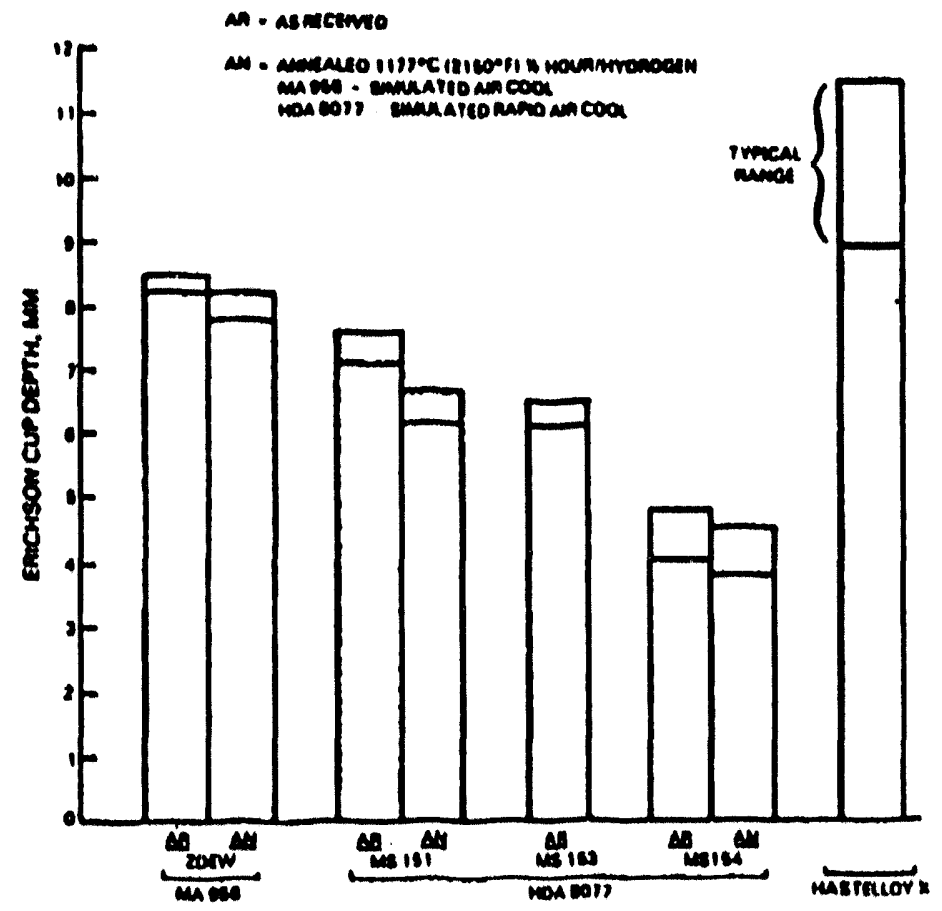

Figure 22. Formability range of various sheet alloys. 


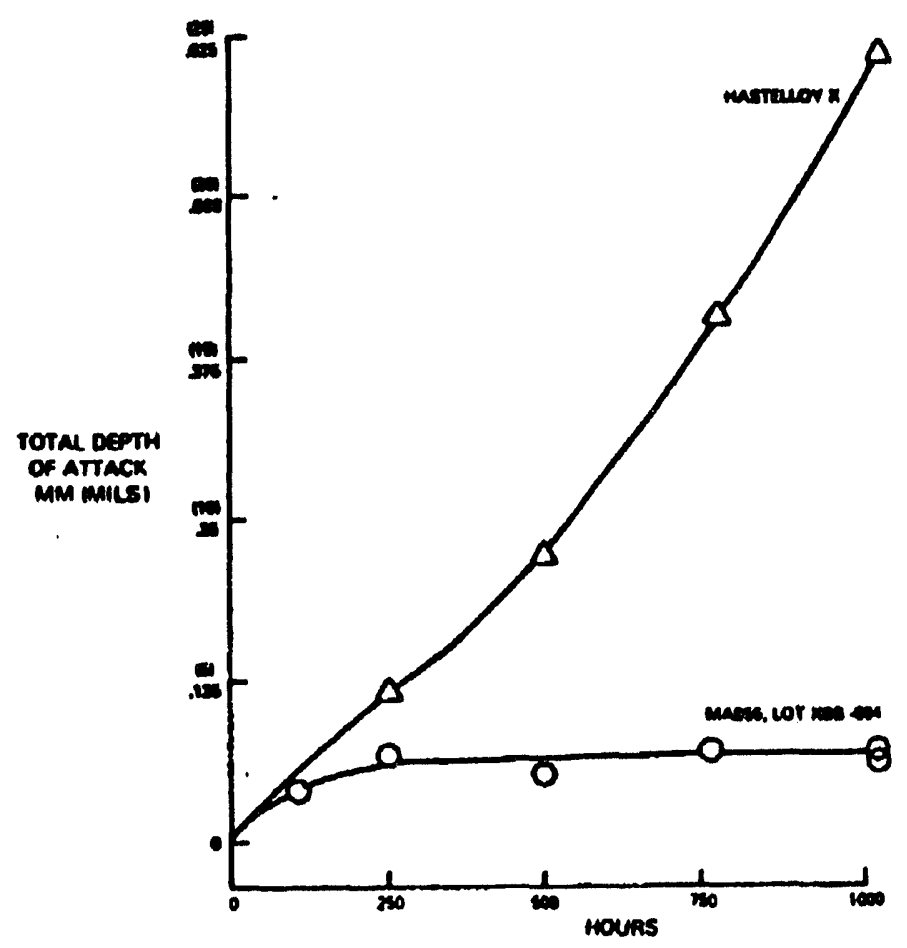

Figure 23. Cyclic oxidation testing at $982^{\circ} \mathrm{C}\left(1800^{\circ} \mathrm{F}\right)-6$ minute cycle.

canoffer a $167^{\circ} \mathrm{C}\left(300^{\circ} \mathrm{F}\right)$ advantage in creep strength, a $167^{\circ} \mathrm{C}\left(300^{\circ} \mathrm{F}\right)$ advantage on cyclic oxidation resistance. However, the family of ODS alloys did not offer any improvement in thermal fatigue. It was also concluded that brazing and riveting are viable methods of attchment of ODS combustor components. Moreover parameters were identified for brazing the ODS alloys to themselves as well as to Hastalloy $\mathrm{X}$. It was also shown that segmentation is a promising combustor design approach to accommodate the limited thermal fatigue capabiliy of ODS alloys. Lastly a hybrid PW2037 inner burner liner consisting of an ODS alloy and Hastalloy $\mathrm{X}$ was designed and constructed.

The environmental and the mechanical properties of industrial burners differ from that of aircraft. In any program these properties must be experimentally determined. 


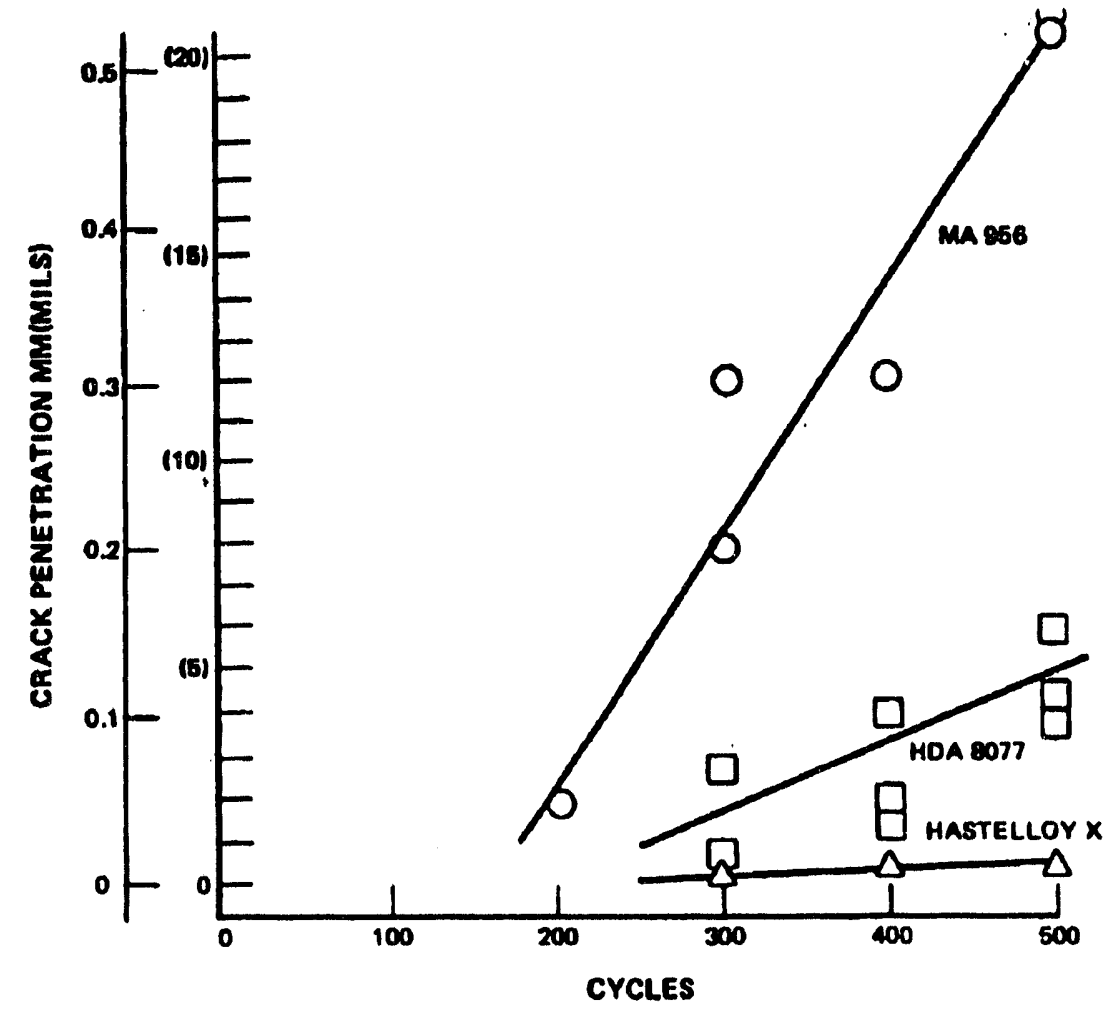

Figure 24. Hot spot blister thermal fatigue test cold wall cracking comparison.

LONGITUDINAL CREEP-RUPTURE PROPERTIES OF

HA 956 LOT ZDEW AT $1093^{\circ} \mathrm{C}\left(2000^{\circ} \mathrm{F}\right), 68.9 \mathrm{MN} / \mathrm{m}^{2}$ (10 KSI)

\begin{tabular}{c} 
Time to 0.1 Percent \\
Creep Hours \\
\hline
\end{tabular}

3.5

7.0
Tine to Rupture

Hours

582.3

137.7
Prior Creep

Percent

0.66

0.39
R. T. Elongation

Percent

\section{4}

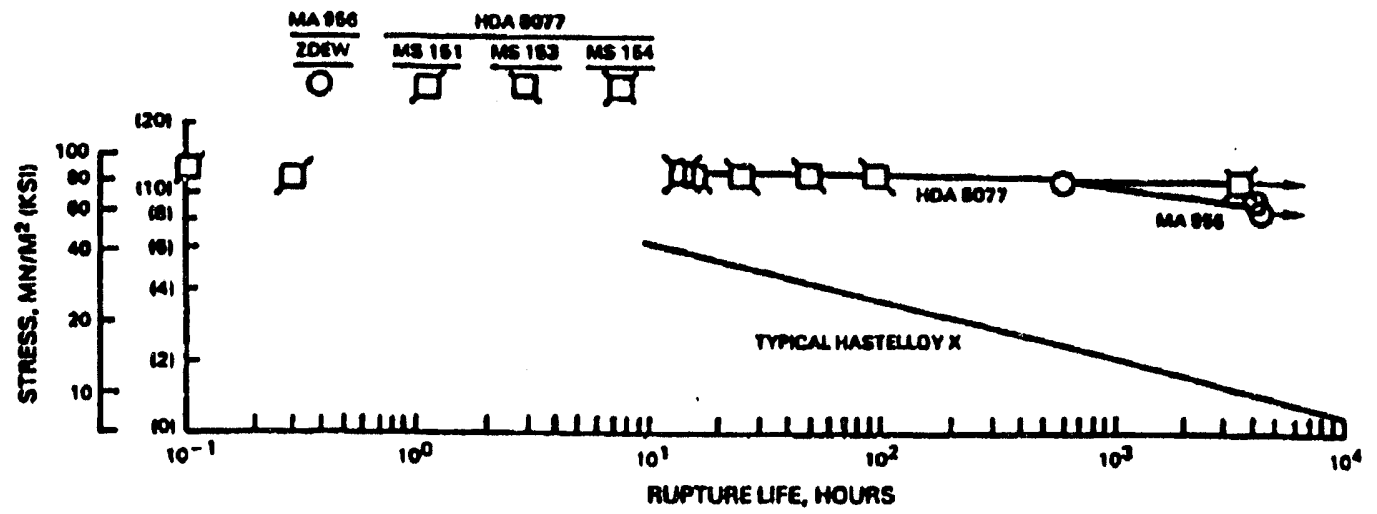

Figure $25.982^{\circ} \mathrm{C}\left(1800^{\circ} \mathrm{F}\right)$ rupture life of various sheet alloys (oxide dispersion strengthened alloys tested parallel to rolling direction). 


\section{REFRACTORY - SLAG INTERACTIONS}

\section{Refractory Experiments}

Norton Company and A.P. Green donated SiC and alumina refractories for slag corrosion testing. The materials included a SiC gunning mix (GC-950) from Norton Company and a SiC castable (Green IC80) and an alumina-silica castable (Express 27) from A.P. Green (Table 5). Although their compositions are almost identical, the Norton $\mathrm{SiC}$ has a thermal conductivity twice that of the A.P. Green $\mathrm{SiC}$, which may be related to the installation method.

Table 5. Technical data for Norton and A.P. green refractories.

\begin{tabular}{|c|c|c|c|}
\hline Material Name & GC-950 & Green IC80 & Express 27 \\
\hline Type & Gun Mix & Castable & Castable \\
\hline Maximum Temperature & NA & 1430 & 1480 \\
${ }^{\circ} \mathrm{C}$ & $\mathrm{NA}$ & 2600 & 2700 \\
${ }^{\circ} \mathrm{F}$ & & & \\
\hline Composition, wt\% & 82.0 & 81.4 & 43.7 \\
$\mathrm{SiC}$ & 2.0 & 3.3 & 48.1 \\
$\mathrm{SiO}_{2}$ & 12.2 & 10.6 & 4.2 \\
$\mathrm{Al}_{2} \mathrm{O}_{3}$ & 2.5 & 3.4 & 1.0 \\
$\mathrm{CaO}^{\mathrm{Fe}} \mathrm{O}_{3}$ & & 0.4 & \\
$\mathrm{~W} / \mathrm{mK}_{\mathrm{Btu}} 1366 \mathrm{~K}$ & & & \\
\hline Thermal $\mathrm{Cond} \mathrm{ft}^{2} \mathrm{HF} @ 2000^{\circ} \mathrm{F}$ & 5.6 & 3.7 & 1.0 \\
\hline $\mathrm{Density}$ & & 25.7 & 6.9 \\
$\mathrm{~g} / \mathrm{cm}^{3}$ & 2.56 & & \\
$\mathrm{lb} / \mathrm{ft}^{3}$ & 160 & 153 & 2.45 \\
\hline
\end{tabular}

Samples of each refractory were prepared according to manufacturer's instructions, including prefiring to the exposure temperatures. Each refractory was exposed to a high-calcium, Powder River Basin (PRB) ash and a high-iron Illinois No. 6 ash for 40 hours at 1260 and $1430^{\circ} \mathrm{C}$. The samples were quenched after 40 hours and cross-sectioned. They will be examined optically and analyzed with scanning electron microscopy with energy-dispersive $x$-ray analysis (SEM/EDX) to determine corrosion mechanisms and rates. Analyses of these samples will be reported in the July through September technical progress report.

\section{Ceramic Sting Tests}

In previous testing, it had been determined that either the Carbofrax $11 \mathrm{~L} 1 \mathrm{SiC}$ or Harbide $80 \mathrm{SiC}$ castable refractory would be the best material for the sting test boats. Both materials have similar expansion coefficients to the SiC ceramics, and both showed no reaction with either the Illinois No. 6 or the high-calcium ash at $1090^{\circ} \mathrm{C}$. At $1260^{\circ} \mathrm{C}$, the slags did react somewhat with the refractories, but reaction was limited. 
These two refractories, Carbofrax $11 \mathrm{LI} \mathrm{SiC}$ and Harbide 80 castable, were tested with two types of ceramics in a new refractory boat design. The ceramics used in this experiment included Carborundum's Hexoloy SA SiC and Lanxide's DIMOX SiC/alumina/aluminum composite. In the new boat design, the refractories were formed into four walls around the individual ceramic coupons, leaving the top and base of the coupons exposed, which allows for easier removal of the refractor after the exposure.

The samples were tested at $1430^{\circ} \mathrm{C}$ to determine the integrity of the refractory/ceramic seals. The main concern was that slag would leak through the seals and contaminate the base of the ceramic. After 100 hours of exposure, the samples did not show any evidence of leakage along the seals, although glass from the refractory covered the base of the coupons. At lower temperatures, this glass formation from the refractory should not occur.

\section{$1090^{\circ} \mathrm{C}$ Sting Test}

The 300-hour sting tests at 1090 and $1260^{\circ} \mathrm{C}$ were completed in May and June using four different ceramic materials, which included Hexoloy sintered-alpha SiC (Carborundum), NT230 siliconized SiC (Norton), standard DIMOX SiC/alumina/aluminum composite (Lanxide), and an experimental DIMOX SiC/alumina composite. After further heat-transfer calculations at UTRC, it was determined that the temperature of the ceramic surface in the radiant section of the HITAF would not reach $1430^{\circ} \mathrm{C}$ in the $65 \%$ coal case, therefore the $1430^{\circ} \mathrm{C}$ sting test was omitted. The all coal case, where the wall temperatures may be higher than $1260^{\circ} \mathrm{C}$, should be examined in experiments performed during Phase Two of the Combustion 2000 project.

For the sting tests, four coupons of each material (except the Hexoloy, only three coupons were available) were machined to $50 \times 44 \times 3 \mathrm{~mm}$. Each coupon was to be exposed to the Illinois No.6 ash and the Wyodak ash at 1090 and $1260^{\circ} \mathrm{C}$. For the Hexoloy material, the $1090^{\circ} \mathrm{C}$ Illinois No. 6 exposure was omitted because this ash was not expected to react extensively with the Hexoloy at this temperature.

For the $1090^{\circ} \mathrm{C}$ sting test, seven of the ceramic coupons (one of the Hexoloy and two each of the other materials) were embedded in Carborundum $11 \mathrm{~L} 1 \mathrm{SiC}$ castable refractory boats. The refractory boats were cured for 24 hours, air-dried for 24 hours, then prefired to $1090^{\circ} \mathrm{C}$. No glass formation on the refractory occurred at this temperature. The seals between the refractory and coupons were examined, then 1.3 grams of the appropriate ash was packed onto the surface of the coupons.

The samples were raised to $1090^{\circ} \mathrm{C}$ at a rate of $120^{\circ} \mathrm{C}$ per hour. After approximately 120 hours of exposure, a furnace element broke, causing the sampies to reach ambient temperature. The samples did not have any macroscopic indication of thermai shock from the excursion, so the furnace was repaired and the test was continued for the remaining 180 hours.

After the exposure, the experimental DIMOX samples became detached from the refractory, probably due to a thermal expansion mismatch with the refractory. The other coupons were still held 
firmly in the refractory boats. The samples were examined briefly with an optical microscope, and optical photos were taken. The DIM' $Y$ SiC/alumina/aluminum composite materials had millimeter-sized bumps on the surface not exịnsed to the ash. The bumps may have been extrusions of molten aluminum that oxidized in air. The samples will be machined and examined by SEM/EDX to determine corrosion mechanisms and depths of ash penetration.

\section{$1260^{\circ} \mathrm{C}$ Sting Test}

Two coupons of each material were embedded in Carborundum 11LJ SiC castable refractory boats. The refractory boats were cured for 24 hours, air-dried for 24 hours, then prefired to $1260^{\circ} \mathrm{C}$. No glass formed on the refractory or the ceramic coupons at this temperature. Like the $1090^{\circ} \mathrm{C}$ coupons, the surfaces of the DIMOX SiC/alumina/aluminum samples had sand-size extrusions after prefiring, probably from the residual aluminum in the material. The seals between the refractory and ceramic were examined, then 6.0 grams of the appropriate ash were packed onto the surface of the coupons.

The samples were raised to $1260^{\circ} \mathrm{C}$ at a rate of $120^{\circ} \mathrm{C}$ per hour, and the exposure lasted 300 hours, then the samples were brought to room temperature at the rate of $120^{\circ} \mathrm{C}$ per hour. The samples were examined briefly with the optical microscope, photographed, and sent to UTRC for machining. Some slag leakage occurred between the ceramic/refractory seals due to rapid attack of the refractory by the slag, which was not expected from the previous testing of the refractory.

Both of the Lanxide DIMOX experimental SiC/Alumina composite materials, and one of the Lanxide DIMOX SiC/Alumina/Aluminum samples (exposed to the Wyodak ash) contained cracks on the back surfaces of the coupons after the exposure. These cracks probably formed during the cooling of the furnace because they were not infiltrated by slag, which would have indicated cracking during the exposure. The samples will be machined and examined to determine corrosion mechanisms and depths of ash penetration, and the results will be reported in the next quarterly report.

\section{Corrosion Prevention}

\section{Coal Additives for Corrosion Prevention}

Several possible corrosion mechanisms have been identified for SiC-based refractories and ceramics. Both the high-calcium PRB ash and the Illinois No. 6 ash dissolved the protective $\mathrm{SiO}_{2}$ layer on the surface of the $\mathrm{SiC}$, which exposed the underlying $\mathrm{SiC}$ surface to corrosive slag species, such as iron (Strobel and Hurley, 1993). The slags also dissolved the refractory binder material, which caused the incorporation of aggregate grains into the slag.

Research is heing performed on another project to investigate the use of coal additives to combat corrosion. A liter ture survey was conducted to identify commercially available coal additives used in combustion systems. A summary of that work is presented here since it is directly relevant to ash 
management in a HITAF system. Several common additives used for altering ash and slag properties include copper oxychloride, limestone, dolomite, clay minerals, and sodium compounds (Radway and Hoffman, 1987). Although the literature presents some of these additives for corrosion prevention, most are used to lower ash fusion temperatures to generate a fluid slag. Lowering slag viscosity may increase corrosion of ceramics in contact with the slag. One additive, copper oxychloride, can increase the crystallization rate in a slag with only small additions, which may be useful in corrosion prevention.

Copper oxychloride $\left(\mathrm{Cu}_{2}(\mathrm{OH})_{3} \mathrm{Cl}\right)$ was developed in the 1960 s as a coal additive to mitigate slagging problems (Sanyal, 1990). This compound is added to the coal in small doses (5-10 ppm), unlike most additives which are added in quantities of a few weight percent to change the ash composition. The combustion products of copper oxychloride, $\mathrm{CuO} / \mathrm{Cu}(\mathrm{OH})_{2} / \mathrm{Cu}$ and $(\mathrm{CuCl})_{n}$, have been shown to transiorm dense deposits into porous, friable deposits by promoting crystallization in slags (Sanyal, 1990). The combustion products are dispersed in the vapor phase during the combustion of the coal, and condense and react on the surfaces of the deposits.

A few authors have tried to explain the ability of this additive to alter slag characteristics. Kiss and others (1972) suggested that the copper oxide compounds are reduced by FeO in the slag to produce metallic copper, which provides nucleation centers for crystallization. The ability of copper to oxidize ferrous iron may be useful to prevent corrosion of ceramics in contact with coal slags. Iron in coal slags has been found to attack SiC ceramics rapidly (Ferber and Tennery, 1984). The reaction occurs by the reduction of iron oxides in the slag by $\mathrm{SiC}$, which results in the formation of iron silicides and $\mathrm{CO}$ or $\mathrm{CO}_{2}$. If the presence of copper promotes oxidation, then metallic iron would be unable to form and react with the SiC.

Copper also promotes crystallization of spinel phases, such as hercynite $\left(\mathrm{Fe}^{+2} \mathrm{Al}_{2} \mathrm{O}_{4}\right)$ (Kiss and others, 1972). By the formation of hercynite, the iron would remain in a stable phase and be unable to react with the SiC. The removal of the iron from the slag and the crystal formation would increase slag viscosity, and this would decrease the migration of corrosive species to the ceramic surface. The effects of this additive and others will be determined in laboratory experiments under another project.

\section{Slag Viscosity Modifications}

Altering slag viscosity may aid in corrosion prevention of ceramics in contact with coal slags. Either decreasing slag viscosity or increasing slag viscosity may provide a means to protect the ceramic surface. In an oxidizing atmosphere, a thin layer of $\mathrm{SiO}_{2}$ forms on the surface of $\mathrm{SiC}$ which can act as a protective coating. This layer can dissolve into the slag, leaving the SiC exposed directly to the slag. The preferred surface is the one that dissolves most slowly. The formation of the $\mathrm{SiO}_{2}$ depends on the partial pressure of oxygen at the ceramic surface, which can be influenced by the thickness of the slag layer (Ferber and Tennery, 1984). A thick, viscous slag layer would not allow as rapid oxygen penetration to the ceramic surface, and the diffusion of oxygen would be impeded by the formation of bridging oxygens in the melt. But a viscous slag would be more erosive than a fluid slag due to the shear 
stress on the surface of the ceramic. Also, the diffusion rates of corrosive ions to the SiC surface are much slower in a slag with higher viscosity and fewer non-bridging oxygens. The diffusion rutes of corrosive species to the ceramic surface at varying temperatures could be investigated to determine if an optimum slag viscosity and thickness may exist to promote the formation of the $\mathrm{SiO}_{2}$ layer and to prevent diffusion of iron.

Many types of additives, such as limestone, dolomite, sodium, iron, and boron compounds, have been used historically to change the slagging characteristics of coals (Radway and Hoffman, 1987). The main use of these additives has been to lower slag viscosity to generate a fluid slag that will not plug slag taps. The use of sodium additives can cause low-temperature fouling problems, and, due to the increased awareness of air toxics, the use of boron-containing compounds is not recommended

Limestone is commonly used as a calcium additive tc coals to reduce slag viscosity (Radway and Hoffman, 1987). But limestone additives have also been shown to increase the viscosity of molten ash deposits, which decreases the deposit's ability to sinter and develop strength (Gibb, 1986). The different effects of calcium additions are related to the type of coal fired, as well as operating conditions. The ternary phase diagram of the $\mathrm{CaO}-\mathrm{SiO}_{2}-\mathrm{Al}_{2} \mathrm{O}_{3}$ systems indicates that in low-calcium coals, the addition of $\mathrm{CaO}$ would reduce the liquidus temperature (Ehlers, 1972). With high-calcium coals, additions of $\mathrm{CaO}$ would increase the liquidus temperaturc. These predictions are based on simple ternary systems and do not consider the effects of small amounts of fluxing agents, such as sodium or iron, on the liquidus temperature of the melt. Experiments are proposed under another project to determine the effects of calcium additions on slag viscosity.

Clay sediments usually contain abundant clay minerals, such as kaolinite. Kaolinite is a hydrous aluminosilicate $\left[\left(\mathrm{Al}_{2} \mathrm{SiO}_{5}(\mathrm{OH})_{4}\right]\right.$ which forms fine particles in sedimentary rocks. Due to its relatively high alumina-to-silica ratio, kaolinite has the ability to increase the liquidus temperature of some deposits, which reduces deposition problems (Radway and Hoffman, 1987). This may aid in corrosion prevention of a ceramic surface. The formation of a viscous slag layer on the ceramic may impede the migration of corrosive species to the ceramic surface. This protective layer could be maintained by intermittent pulsing of the additive to produce the viscous layer. The pulsing would allow a thin, protective layer to form but would not allow the buildup of thick deposits because the pulses would be intermittent. The bulk of the slag would be less viscous and flow freely over the "frozen" stag layer.

\section{Model Slag Behavior}

Work concluded on the incorporation of the model for flow of slag in vertical layers with the radiant heat transfer model. The improved model takes into account the change in slag viscosity and temperature with slag layer thickness. This is a more realistic treat: ent of the effect of slag on heat transfer.

A parametric study was completed using the new version of the radiant heat transfer model, incorporating the variable viscosity slag model. The following parameters/conditions were varied: 
- Air flow (parallel vs. countercurrent)

- Gas temperature

- Refractory wall thickness

- Ash deposition rate

Parallel flow produces a dry ash layer of constant thickness with a slowly increasing liquid slag layer. Countercurrent flow, in contrast, produces a rapid increase in the dry ash layer thickness at the bottom of the reactor where the air is cold. Parallel flow seems preferable because a nearly constant heat flux is maintained down the length of the air heater. Furthermore, at a gas temperature of 2900$)^{\circ} \mathrm{F}$ with parallel flow, the refractory surface temperature is in the range of 2200 to $24000^{\circ} \mathrm{F}$. For countercurrent flow, the refractory surface temperature reaches $25000^{\circ} \mathrm{F}$ at the top of the combustor. To reduce the risk of refractory corrosion, the refractory surface temperature should be kept low. This may provide another reason for preferring parallel flow.

Decreasing the thickness of the refractory layer causes the dry ash layer thickness to increase. There is almost no effect on the length of the radiant air heater, although the overall resistivity increases as the refractory is made thinner because the ash layer has a lower thermal conductivity than the refractory. This seems to indicate that if the refractory reacts with the ash and is gradually "replaced" by dry ash, there shouldn't be a major change in heat transfer. 


\section{COMMERCIAL PLANT DESIGN}

The plant plot plan has been updated to reflect revisions to the combustor designs, and to include further details of the systems around the combustor area. The enginecring and design work summarized by the plot plan are presented for the following major items.

- Coal handling and preparation

- Fluc gas desulfurization

- Plant steam and cooling water

- Wastewater treatment

The conceptual estimate for auxiliary power requirements of major equipment and operations is also presented. Preliminary major equipment lists for cost estimating are contained in Appendix $A$.

\section{Plot Plan}

Figure 26 shows the conceptual plot plan for the power plant. The facilities were designed and sized based on experience with similar pulverized coal-fired plants. Figures 27, 28, and 29 show views of selected plant areas.

The major components shown on the plot plan, and the selected operating processes are summarized in the sections below.

\section{Coal Handling}

The major items in the design of this system include the following.

- Railcar recciving and unloading

- Active coal storage in concrete silos

- Inactive (dead coal) and emergency storage in upen, ground storage piles

- Conveyors and other material handling equipment required to transport coal safely and with minimum environmental impacts

Figure 26 showed the plot plan for the entire plant, and illustrates the overall coal storage and handling design. Figure 30 shows the concept and the equipment in more detail. 'The major equipment list in Appendix A provides specifics about the equipment at a level of detail sufficient for conceptual cost estimating.

\section{Coal Receiving and Storage}

With reference to Figure 30, two inch topsize coal is delivered by rail in bottom dump cars. The plant's coal receiving scope includes the rail loop for cost estimating, hut for process description 


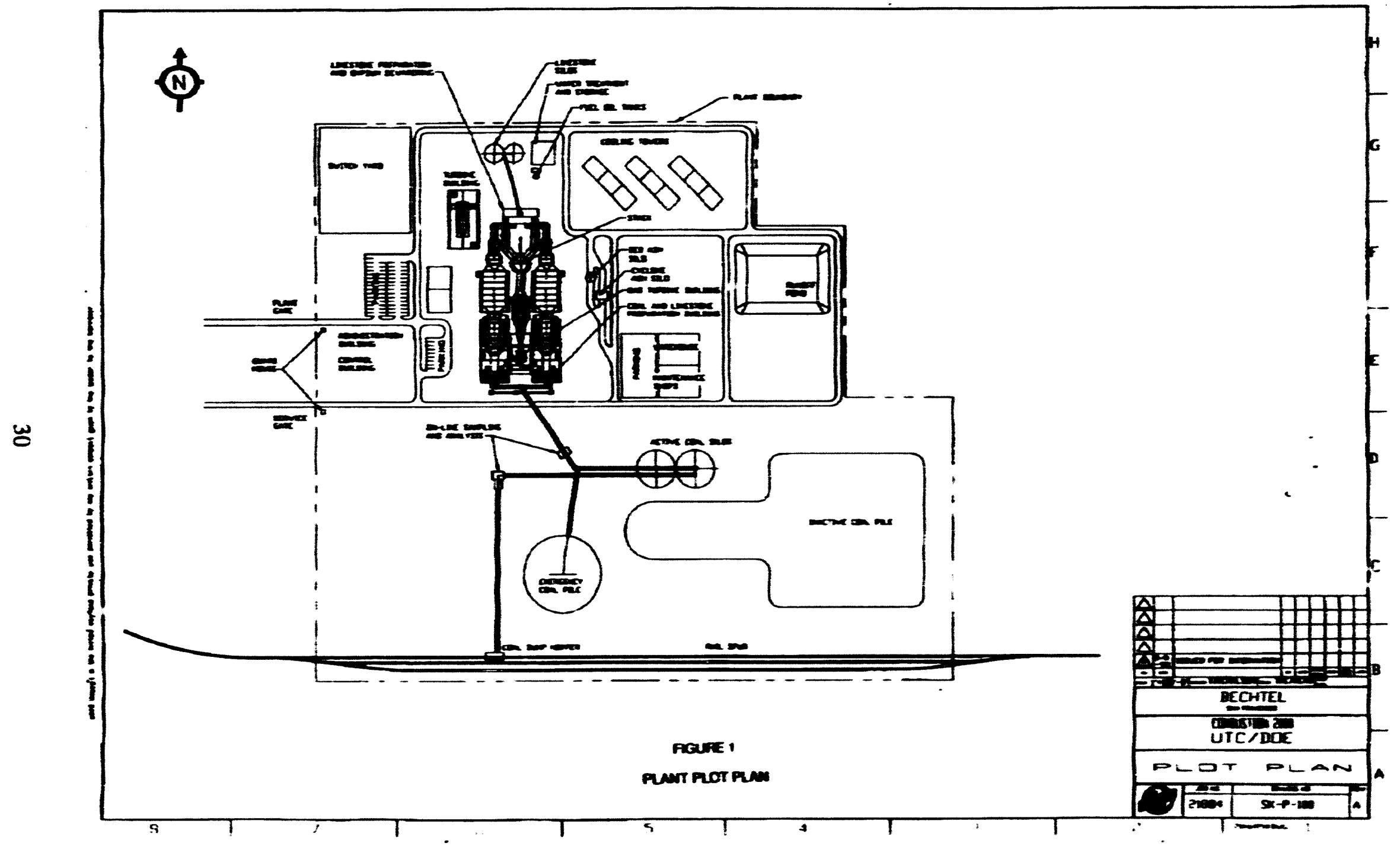

Figure 26. Plant plot plan. 


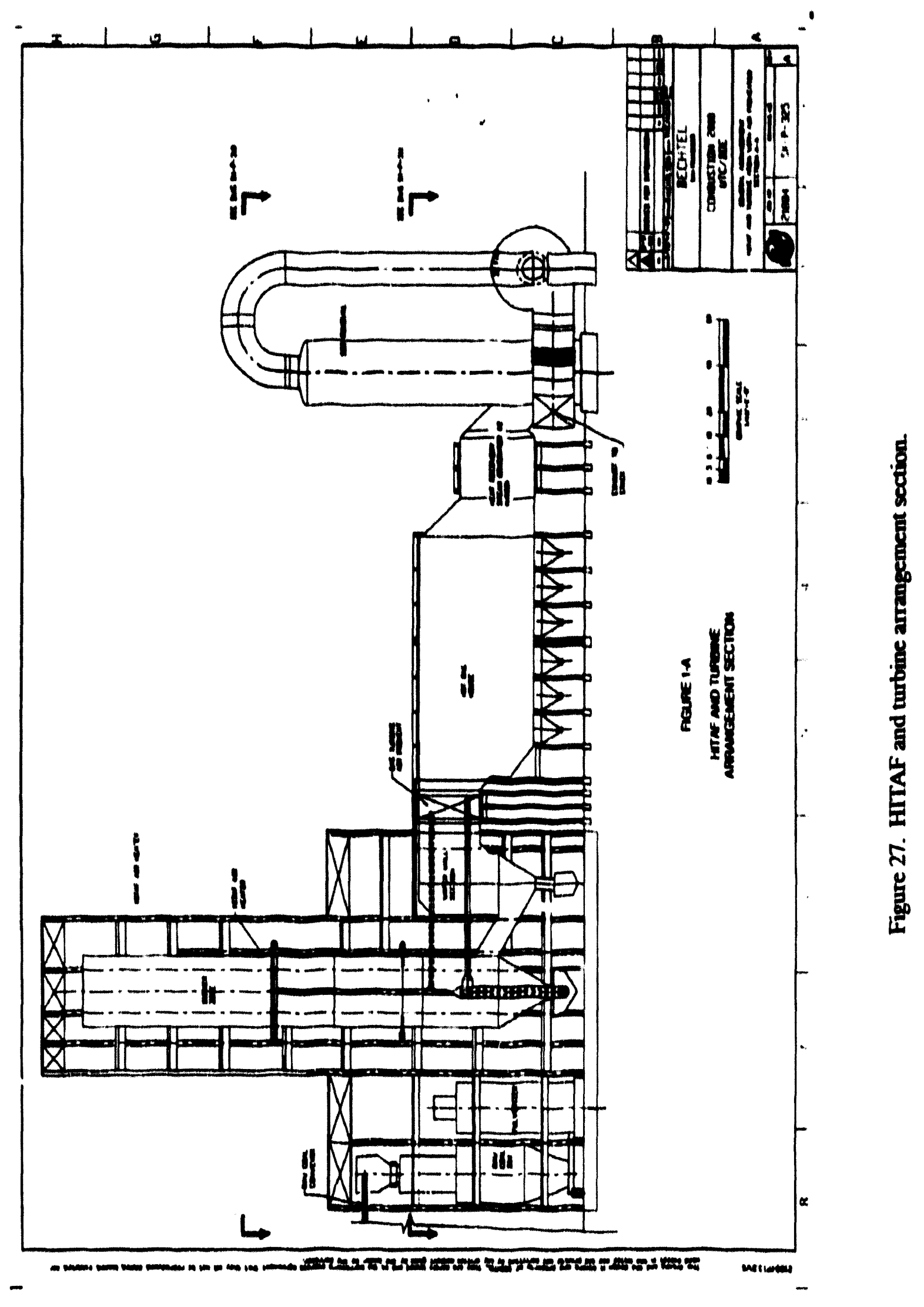




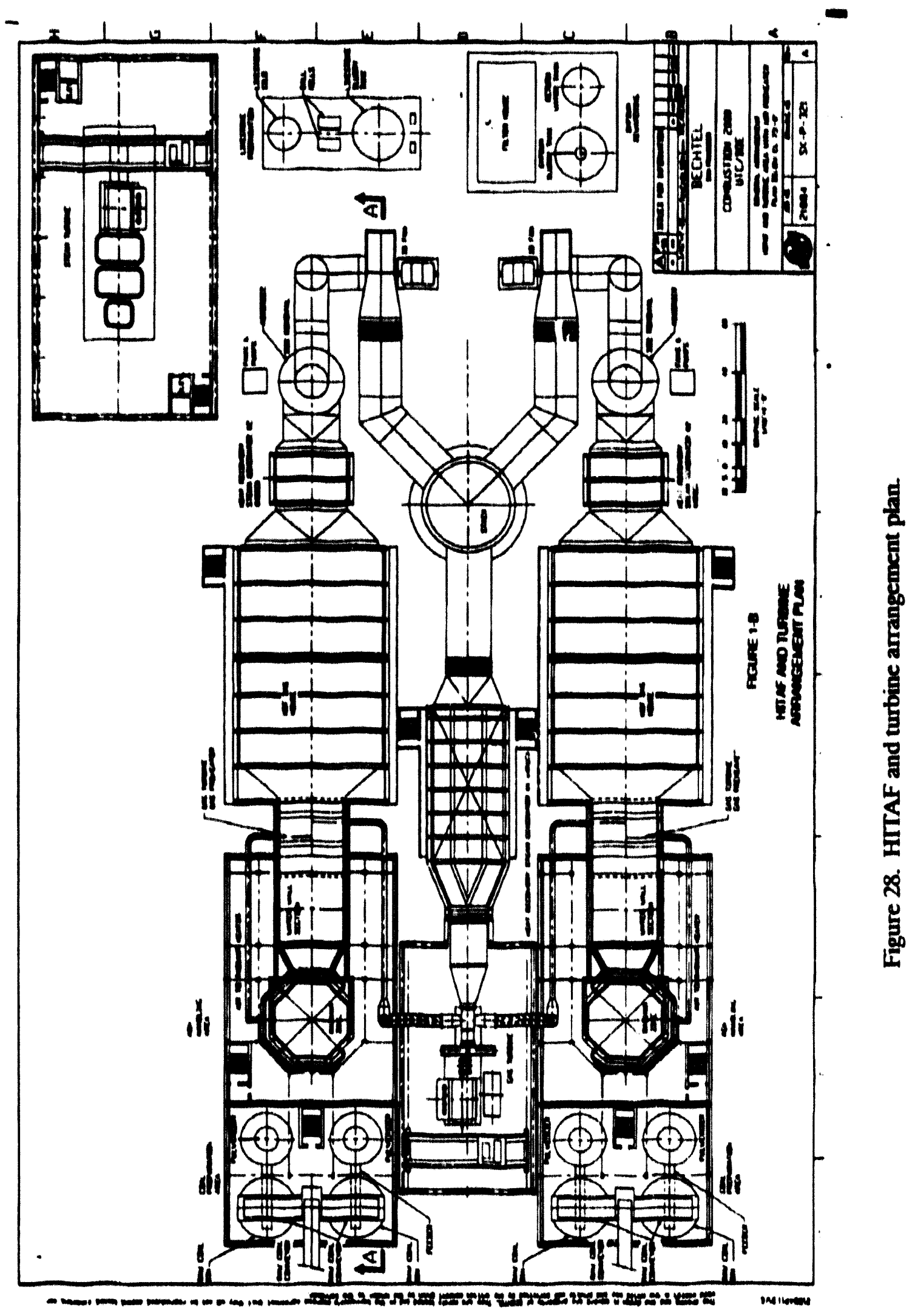




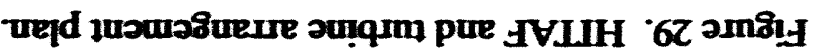

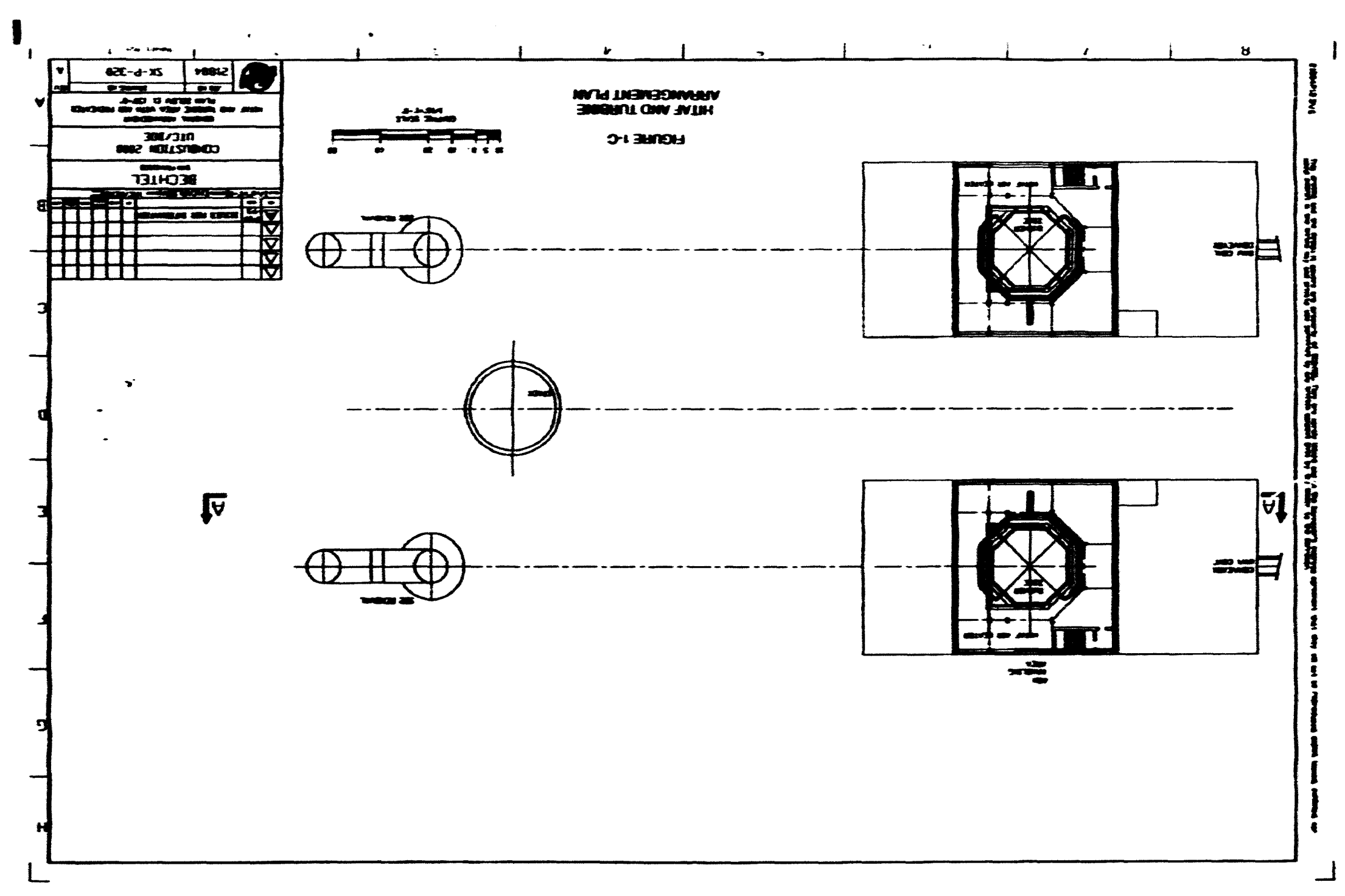




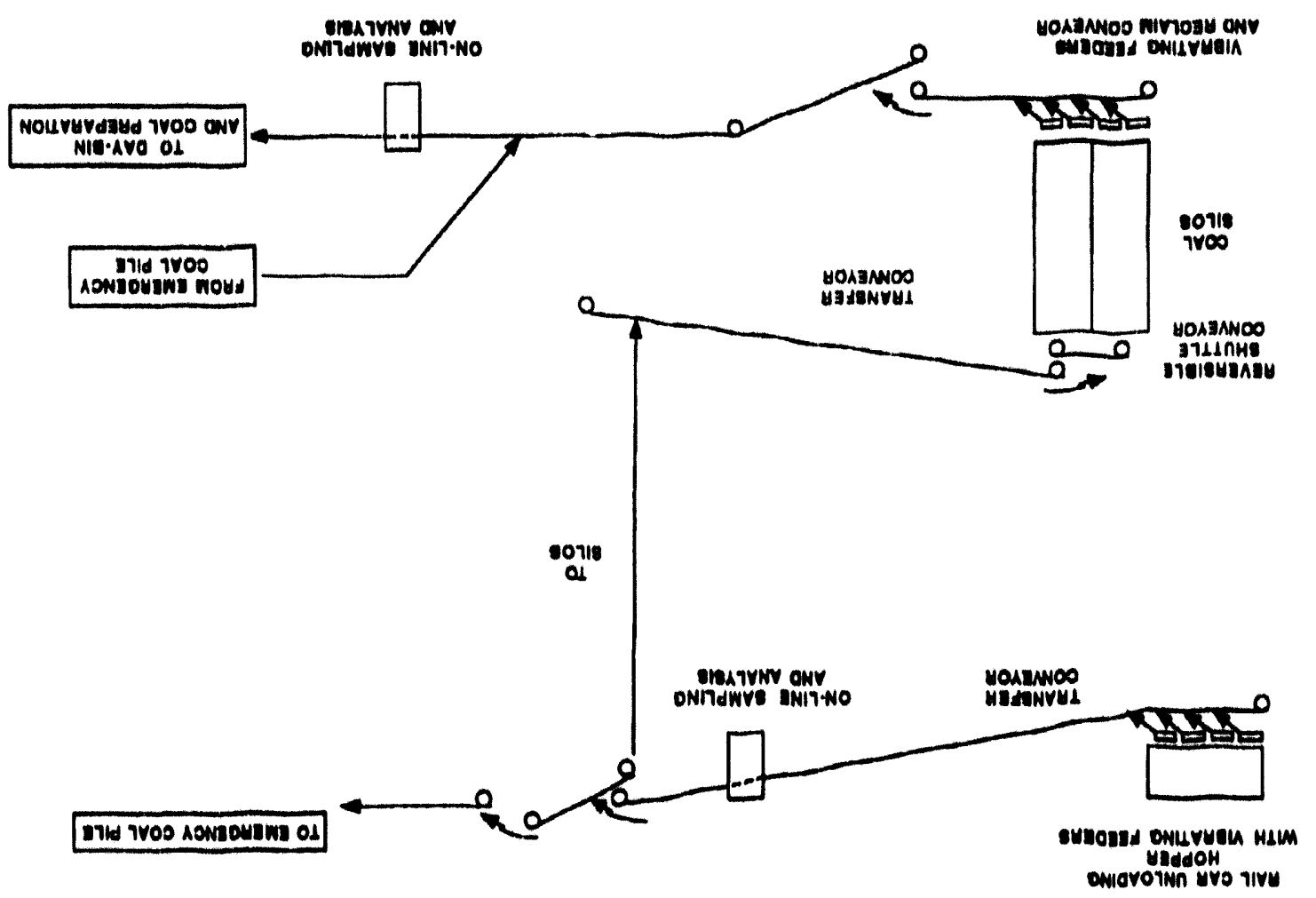

Figure 30. Coal storage and handling.

purposes the system begins with the unloading hopper. The hopper is actually a series of bins with vibrating feeders and conveyors which rapidly remove the coal and send it to storage. In this design the coal train can be quickly unloaded and released for other duties.

Coal from the receiving hopper is placed on the main transfer conveyor. This 60 inch belt conveyor has a capacity of 2,000 tons per hour (tph), and as indicated by the plot plan, can feed directly to the active coal silos, or an emergency ground pile. Coal in the emergency pile can be reclaimed and sent to either the silos, or to the inactive storage.

Coal from the silos, or the emergency pile is reclaimed and conveyed at 100 tph to a day-bin storage directly ahead of the coal preparation system's grinding mill feed bins.

The two concrete silos are 80 feet in diameter and 180 feet high. The total capacity is 25,000 tons, or approximately three weeks of coal at the maximum design rate of $54 \mathrm{tph}$. The inactive storage contains some 120,000 tons of coal or about three months of reserve.

\section{Other Material Handling Issues}

Dust control and/or collection for safety and housekeeping is extensive throughout the system and especially at coal transfer points. Conveyors are enclosed. The open coal piles are compacted and 
provided with a polymer spray to prevent dust and to minimize the potential for "hot spots" or coal pile fires.

The coal handling system includes belt weigh scales and on-line coal sampling and analysis as part of the raw coal accounting and quality control features. Coal quality information as well as other operating and maintenance data is sent to a central control room for monitoring with the other plant conditions.

\section{Coal Preparation}

Figure 31 illustrates the coal preparation system. Reclaimed coal from storage is ground and dried prior to use as fuel in the combustor. Two operating trains of equipment with 50 percent $(27 \mathrm{tph})$ capacity each, and two installed spare trains are used. Each grinding and drying train supplies coal to one of the two combustor units.

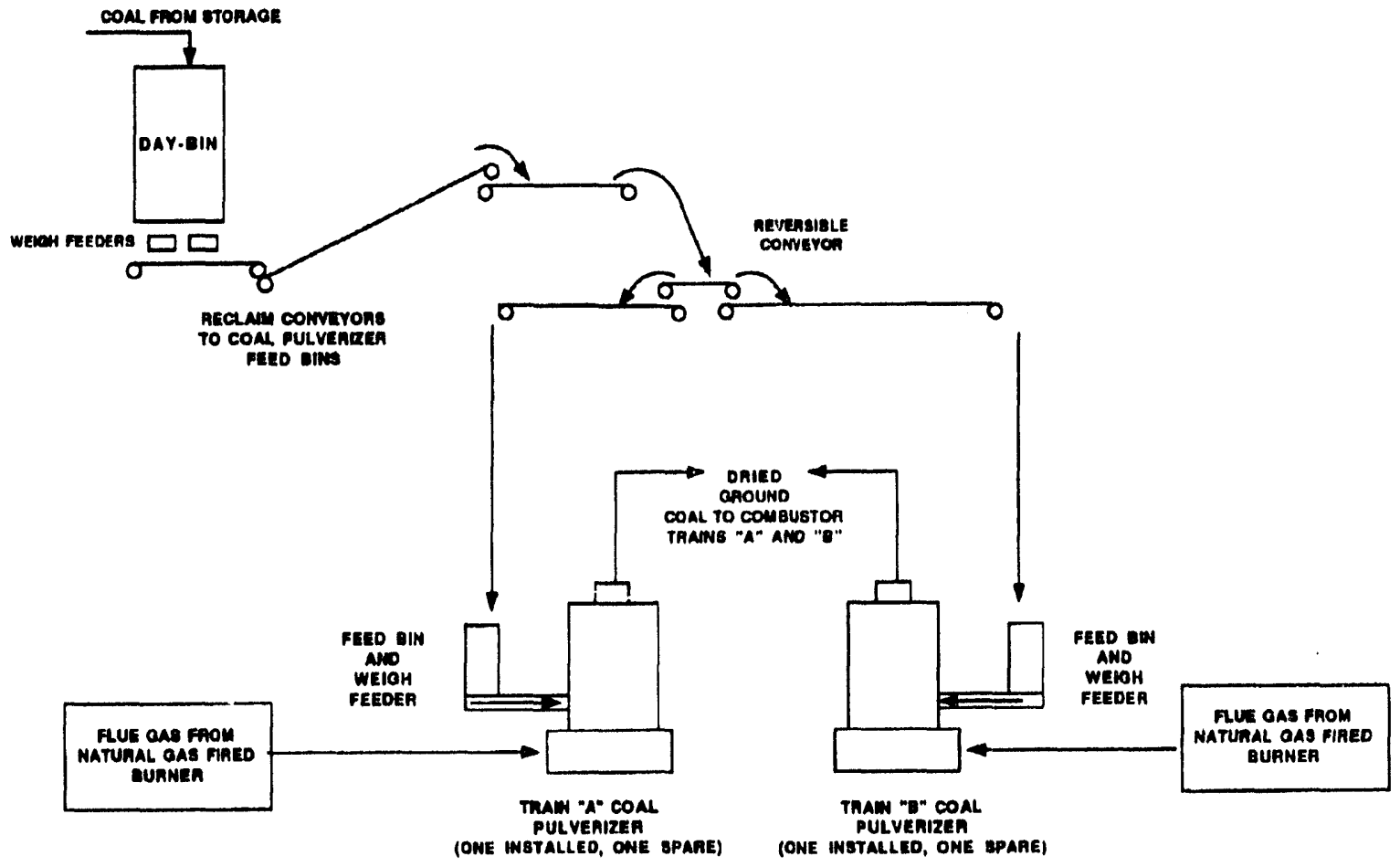

Figure 31. Coal preparation.

Coal from the day-bin is transferred to surge bins directly ahead of the grinding equipment. The coal is weighed and feed to the mills where it is dried to 5 percent total moisture.

The grinding and drying operation is performed by gas swept pulverizers similar to commercial units used in pulverized coal-fired power plants. The ground coal in internally classified. The drying 
fluid is an oxygen deficient combustion product produced by burning natural gas. The hot flue gas is sent to the pulverizer at $400^{\circ} \mathrm{F}$. The ground coal is dried to 5 percent total moisture, and is pneumatically transported to the combustor by the gas. Future trade studies may be used to locate other sources of heat, or a hot flue gas, to use as the drying and transport medium.

\section{Flue Gas Desulfurization}

The limestone forced oxidation process with a limestone-water slurry and throw-away product system is used for the conceptual design. The process selection is based on engineering experience and the estimated process economics, auxiliary power requirements (pressure drop) and potential for sulfur reduction. The throw-away product assumes there is not a market for gypsum, and if that assumption were to change, the process design selection may be reviewed.

\section{Limestone Forced Oxidation FGD Process}

In the limestone forced oxidation process, flue gas containing $\mathrm{SO}_{2}$ is sent to an absorber tower, where the gas is contacted with a 10 to 15 percent by weight slurry of calcium carbonate and calcium sulfite/sulfate. The sulfite formed by $\mathrm{SO}_{2}$ absorption is oxidized to sulfate by forced air injection at the bottom of the absorber. The resulting slurry is dewatered in a hydroclone and vacuum filter to produce a gypsum filter cake with less than 10 percent moisture. The overall reaction is summarized below.

$$
\begin{aligned}
& \mathrm{CaCO}_{3}+\mathrm{SO}_{2}+1 / 2 \mathrm{H}_{2} \mathrm{O}-->>\mathrm{CaSO}_{3} \cdot 1 / 2 \mathrm{H}_{2} \mathrm{O}+\mathrm{CO}_{2} \text { (Absorption) } \\
& \mathrm{CaSO}_{3} \cdot 1 / 2 \mathrm{H}_{2} \mathrm{O}+1.25 \mathrm{O}_{2}-->\mathrm{CaCO}_{4} \cdot 2 \mathrm{H}_{2} \mathrm{O} \text { (Oxidation) }
\end{aligned}
$$

\section{Limestone Slury Preparation}

$3 / 4$ inch limestone is received by truck or rail, and delivered by movable conveyors and mo' 'le equipment to two 5,000 ton silos. The combined capacity is equivalent to 60 days of limestone reserves. Limestone is reclaimed from the silos and sent to a 200 ton day-bin prior to slurry preparation.

Slurry preparation begins with limestone grinding in wet ball mills. The $3 / 4$ inch limestone is ground to 90 percent passing 200 mesh. The 60 percent solids by weight ball mill slurry is diluted to 20 percent by weight and pumped to the limestone slurry tank for use in the absorbers. Figure 32 shows the limestone preparation concept. Grinding is performed in a single mill and the plant includes an installed spare mill.

\section{Flue Gas Cleaning (Scrubbing)}

The FGD design has two absorber towers to serve the two combustion trains. Each tower is sized at the maximum load, 105 percent of design gas flow. The towers are vertical open spray designs with counter current contact between the flue gas and the limestone slurry. Each tower has four spray levels to saturate the flue gas and remove $\mathrm{SO}_{2}$. A recycle pump is required for each spray level. The scrubbed 


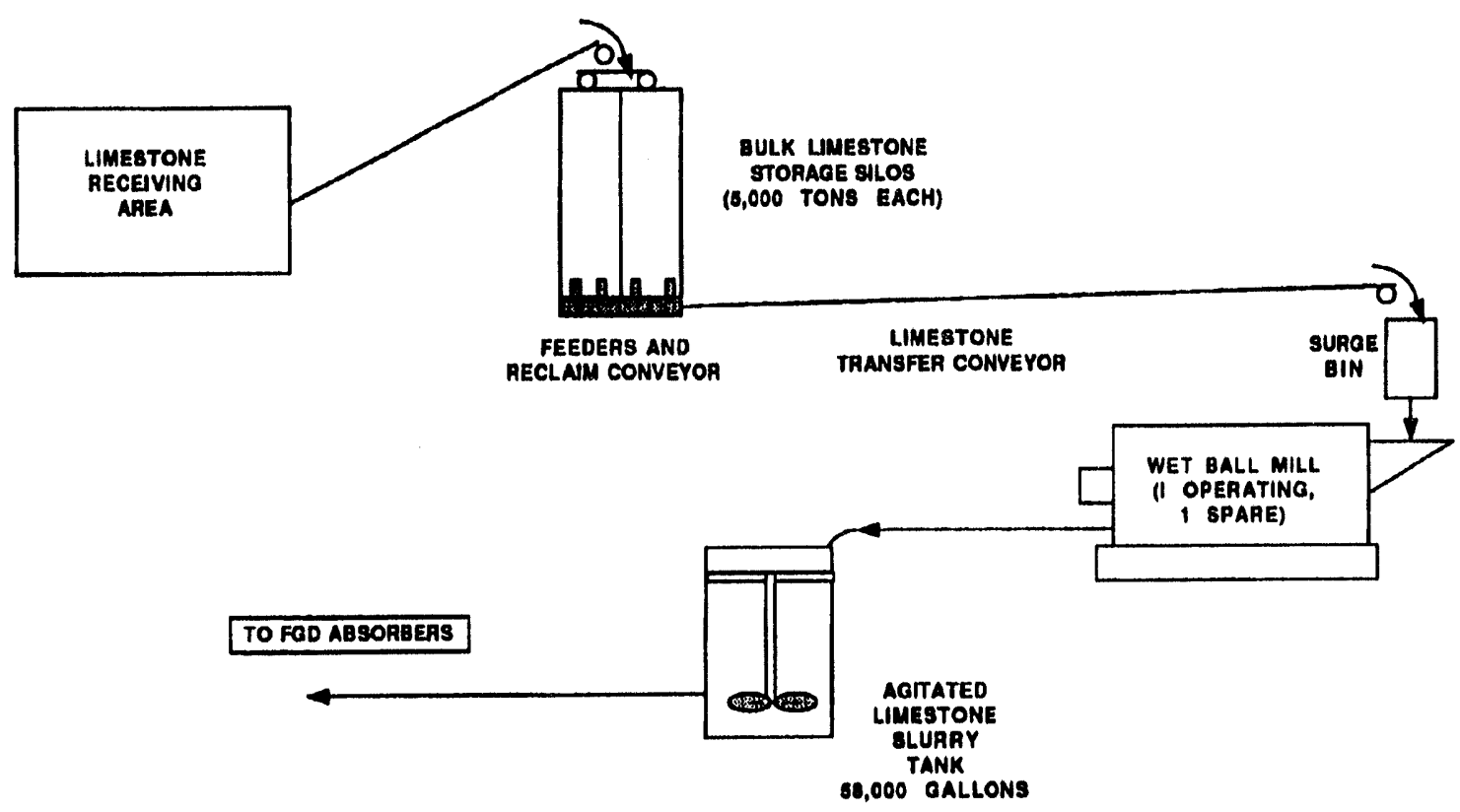

Figure 32. Limestone preparation.

flue gas passes through chevron mist eliminators to remove entrained water droplets prior to leaving the tower. A limestone slurry to gas ratio of 100 gallons per minute per 1,000 actual cubic feet per minute is the design basis for sizing the recycle pumps. The absorber tower design is based on a superficial gas velocity of 10 feet per second.

For the design coal higher heating value, $\mathrm{SO}_{2}$ removal of 97.62 percent is needed to match the requirement of 0.15 pounds of $\mathrm{SO}_{2}$ per million Btu stack emissions. Combining the coal and natural gas higher heating value, an $\mathrm{SO}_{2}$ removal of 96.36 percent is required for the 0.15 pounds emission limit. The FGD system is designed to remove 98 percent of the $\mathrm{SO}_{2}$. At the design point, the $\mathrm{Ca} / \mathrm{S}$ molar ratio is 1.05 , and the design limestone contains 90 percent $\mathrm{CaCO}_{3}, 9$ percent $\mathrm{MgCO}_{3}$ and inerts, and 1 percent moisture.

The scrubbed flue gas from the two absorbers are sent to a 300 foot tall stack and released to the atmosphere. Exhaust gas from the gas turbine heat recovery steam generator is sent to the same stack where it mixes with the flue gas and provides some reheat energy. The estimated temperature of the mixed stack gas is $152^{\circ} \mathrm{F}$ at the stack exit.

\section{FGD Solids Dewatering}

The scrubbing spray slurry is collected in the bottom of the absorber towers, providing 6 minutes retention time for the chemical reactions. Compressed air is injected with a sparger into the collected mixture to promote the oxidation reaction. A bleed stream with 15 to 20 percent solids from the absorber bottom is pumped to a hydroclone for preliminary dewatering. The hydroclone underflow 
with 40 to 50 percent solids is dewatered to 10 percent moisture content ( 90 percent solids) in a vacuum filter. The gypsum filter cake is conveyed to temporary storage and trucked offsite for disposal with the combustion fly ash.

A simplified process flow diagram of the FGD system is shown in Figure 33.

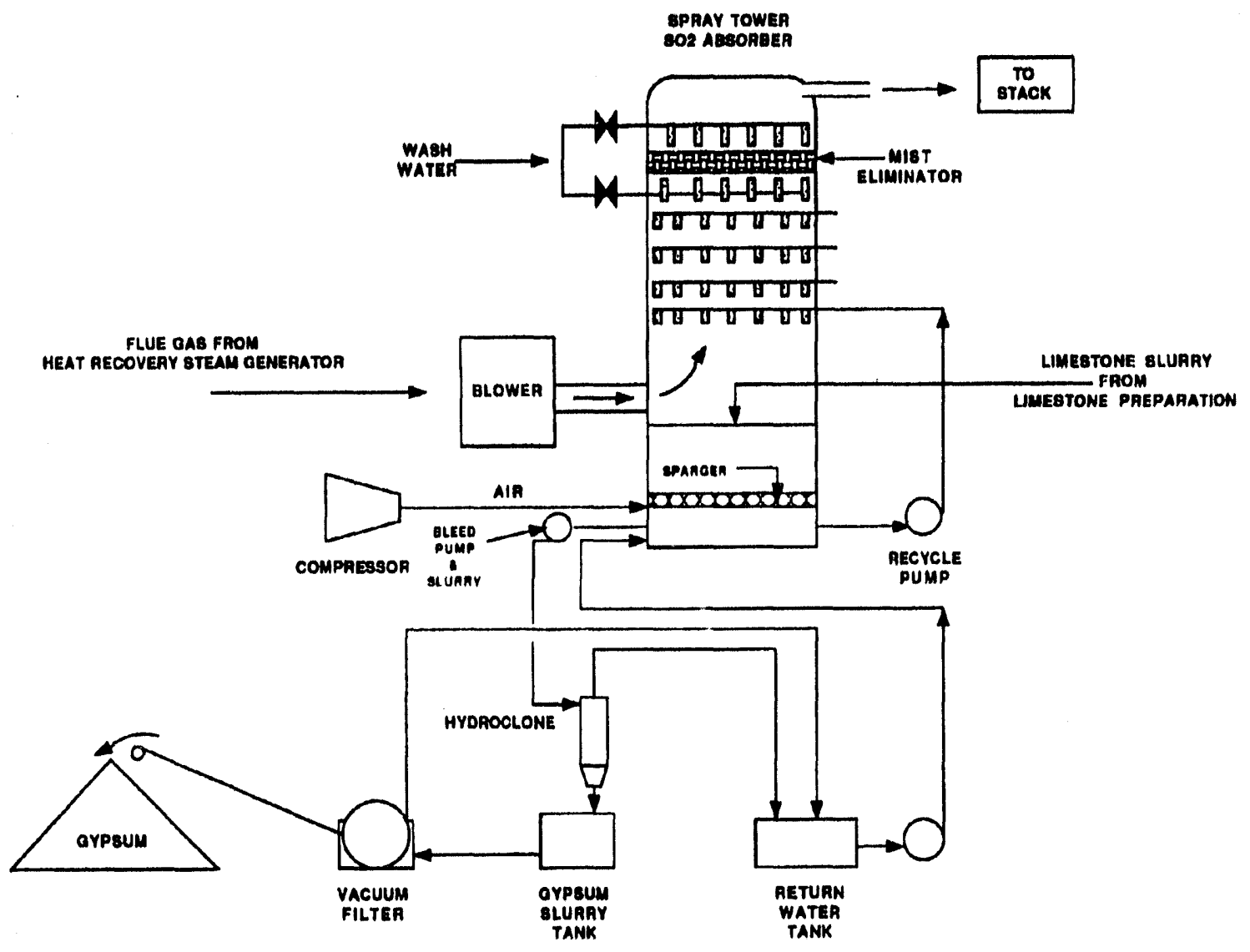

Figure 33. Wet limestone scrubbing with forced oxidation.

\section{Plant Steam and Cooling Water}

\section{Steam and Condensate}

Two heat recovery steam generator (HRSG) sections are thermally integrated to generate 2400 psia $/ 1000^{\circ} \mathrm{F} \mathrm{SH}$ and $540 \mathrm{psia} / 1000^{\circ} \mathrm{F} \mathrm{RH}$ steams. The steam is used in a multiple pressure turbine to generate electric power. Steam from the low presssure turbine exhausts at 3 inches $\mathrm{Hg}$ absolute and is condensed by a shell and tube surface condenser. The cooling water flow is $62,400 \mathrm{gpm}$. The condenser therma duty is 687 million Btu/hr. The condensate is combined with boiler feedwater makeup and pumped to a deaerator. From the condensate pump discharge the feedwater flows through a series of low-pressure heaters and then to a deaerator. The blowdown rate is 1 percent of the 
high pressure steam flow. The makeup feedwater rate is about $7,700 \mathrm{lb} / \mathrm{hr}$. The boiler feed pump is supplied from the deaerator and the feedwater is routed through the economizer.

\section{Heat Rejection}

Cooling water for the steam condenser is cooled from $102^{\circ} \mathrm{F}$ to $80^{\circ} \mathrm{F}$ with a forced draft wet cooling tower. A wet bulb temperature $: 75^{\circ} \mathrm{F}$ is used to design the cooling tower. The cooling water makeup rate is about $1590 \mathrm{gpm}$. The mancup accounts for evaporation losses of $1172 \mathrm{gpm}$, blowdown of $292 \mathrm{gpm}$ (after 5 cycles) and a drift loss of $126 \mathrm{gpm}$.

The equipment list for steam and water system is shown in Appendix A.

\section{Boiler Feedwater Treatment}

The raw water analysis data indicates that a boiler feedwater pretreatment system will be required to meet the following impurity limits:

$\begin{array}{ll}\text { Total Hardness as } \mathrm{CaCO}_{3} & <10 \text { ppbw } \\ \text { Iron as } \mathrm{Fe} & <10 \mathrm{ppbw} \\ \text { Silica as } \mathrm{SiO}_{2} & <20 \mathrm{ppbw} \\ \text { Total Dissolved Solids } & <100 \mathrm{ppbw}\end{array}$

The boiler feedwater treatment system will be required to provide about $7,700 \mathrm{lb} / \mathrm{hr}$ of demineralized makeup water for the high pressure steam cycle. The following steps are commonly used to pretreat the raw water:

- Mixed media filtration

- Cation exchange

- Anion exchange

- Mixed bed exchange

The wastewater generated from the demineralizer system consists of backwashes and rinses and caustic wastes. These streams must be neutralized prior to reuse or discharge.

\section{Wastewater Treatment}

Environmental issues, including waste water treatment will significantly impact plant cost and schedule. A state mandated National Pollutant Discharge Elimination System (NPDES) permit for air and water is required before a construction license can be issued.

The major sources of wastewater streams for power plants can be identified as:

- Coal and limestone preparation systems 
- Pretreatment and Demineralizer washes

- Cooling tower and HRSG blowdowns

- Rainfall runoff from coal piles and FGD/ash disposal areas

- Equipment washes

- Sanitary waste treatment effluent

- FGD wastewater stream

The conventional discharge parameters are based on EPA guidelines for power plants, and include $\mathrm{pH}$, oil and grease, suspended solids, residual chlorine, iron and copper. Other parameters restricted by state NPDES permits (depending on the receiving stream classification) may include dissolved oxygen, phosphorous, temperature, other trace metals (such as zinc, nickel, etc.), and dissolved solids.

The choice of wastewater treatment and discharge, or zero discharge depends on plant location, type of pretreatment required for the raw water and the discharge regulations.

Conventional waste treatment often involves combining wastewater streams according to treatment categories and treating those streams prior to discharge. As a minimum, the following are considered conceptual design requirements for treating the waste streams prior to discharge:

- Oil/water separator for removing traces of oil and grease from the floor drains and runoff streams

- Neutralization of the waste streams to adjust the $\mathrm{pH}$, generally between 6.5 and 8.5

- Settling and clarification to remove solids

The single largest category of wastewater from the plant is blowdown from the wet cooling tower. This stream must be treated to meet phosphorous and TDS limits, temperature, residual chlorine, copper, iron, other metals and $\mathrm{pH}$ requirements.

\section{Raw Water Treatment}

The plant's raw water from Lake Michigan will require treatments for sedimentation, clarification, filtration, carbon adsorption, chlorination and softening to provide potable and process quality water.

\section{FGD Wastewater}

During combustion, chloride in coal is converted to hydrogen chloride which, being highly soluble, is captured by the FGD scrubber. The reactivity of limestone is reduced by high chloride 
concentrations, and blowdowns of the system are necessary to remove and dilute the scrubber chloride concentration, and to limit the chlorides to a pre-determined concentration. As shown in Figure 33, a bleed stream is withdrawn from the oxidation tank and dewatered to yield a filter cake (usually about 20 percent by weight residual moisture) and chloride-rich water. To limit the chloride concentration in the scrubber loop (10 to $15,000 \mathrm{mg} / \mathrm{l}$ is tolerated), some of the separated water is purged and the rest is returned to the scrubber or as limestone slurry makeup water. The purged water stream is treated to meet NPDES limits.

Depending on the composition of the waste stream, a number of treatment methods are available ranging from clarification and neutralization to evaporation/crystallization which can be designed to meet discharge limits. A decision will also be needed to treat FGD wastewater stream alone, or in combination with other plant waste streams.

\section{Sanitary Wastewater}

Sanitary wastewater is collected at a central wetwell and routed to the treatment plant. Sanitary wastewater is treated by an extended aeration process. The effluent from the second stage flows into a clarifier zone where biological solids settle out and are recycled. Clarified effluent may be used as a cooling tower makeup water, or can be mixed with other waste streams for further treatment to meet NPDES limits before discharge.

Rainfall runoff and drains from plant equipment washes are combined and treated for the removal of oil, grease, and suspended solids prior to discharge. The rainfall runoff from the temporary FGD/ash storage and disposal areas must be monitored for pollutants.

\section{Auxiliary Power Consumption Estimate}

As a preliminary estimate of auxiliary power requirements the following table was prepared. As other major items are identified, the table will be updated.

Table 6. Preliminary estimate of the auxiliary power requirements.

\begin{tabular}{|c|c|}
\hline Item & Operating KWE \\
\hline Coal Handling and Preparation & 1,600 \\
\hline Limestone Preparation and FGD & 1,600 \\
\hline Large Fans and Blowers & 2,200 \\
\hline Steam and Condensate & 2,900 \\
\hline Heat Rejection (cooling tower) & 1,700 \\
\hline Plant lighting, Miscellaneous and Transformer Losses & 1,000 \\
\hline SUBTOTAL & 11,000 \\
\hline Gas Turbine Utilities & 1,600 \\
\hline TOTAL & 12,600 \\
\hline
\end{tabular}




\section{REFERENCES}

Chen, S. L., M. P. Heap, D. W. Pershing and G. B. Martin (1982), "The Fate of Coal Nitrogen During Combustion," Fuel, 61, 1218.

DeSocte, G. G. (1975), "Overall Reaction Rates of NO and $\mathrm{N}_{2}$ Formation from Fuel Nitrogen," 15th Symposium (Intemational) on Combustion, The Combustions Institute, Pittsburgh, PA, 1093.

Ehlcrs, E.G. The Interpretations of Geological Phase Diagrams; W.H. Frecmann and Company: San Francisco, 1972.

Ferber, M.K.; Tennery, V.J. "Behavior of Tubular Ceramic Heat Exchanger Materials in Basic Coal Ash from Coal-Oil-Mixture Combustion," Ceram. Bull. 1984, 63 (7), 898-904.

Gibb, W.H. "The Role of Calcium in the Slagging and Fouling Characteristics of Bituminous Coals," Journal of the Institute of Energy, 1986, December, 206-212.

Kiss, L.T.; Lloyd, B.; Raask, E. "The Use of Copper Oxychloride to Alleviate Boiler Slagging," J.Inst.Fuel 1972, April, 203-223.

Kobayashi, H., Howard, J.B. and A.F. Sarofim (1977), "Coal Devolatilization at High Temperatures," 16th Symposium (International) on Combustion, The Combustions Institute, Pittsburgh, PA, 411.

Pershing, D.W. and J.O.L. Wendt (1979), "Relative Contributions of Volatile Nitrogen and Char Nitrogen to $\mathrm{NO}_{\mathrm{x}}$ Emissions from Pulverized Coal Flames," Ind. Eng Chem. Process Des. Dev., 18, 60.

Pohl, J.H. and A.F. Sarofim (1977), "Devolatilization and Oxidation of Coal Nitrogen," I6th Symposium (International) on Combustion, The Combustions Institute, Pittsburgh, PA, 491.

Radway, J.E.; Hoffman, M.S. Operations Guide for the Use of Combustion Additives in Utility Boilers. EPRI CS-5527, Project 1839-3 Final Report, December 1987.

Sanyal, A. "Copper Oxychloride as a Fireside Additive in Coal-Fired Utility Boilers," EPRI GS6751, Project 1839.4 Final Report, February 1990.

Smith, P.J., S.C. Hill and L.D. Smoot (1982), "Theory for NO Formation in Turbulent Coal Flames,"19th Symposium (Intermational) on Combustion, The Combustions Institute, Pittsburgh, PA.

Solomon, P.R. and M.B. Colket (1978), "Evolution of Fuel Nitrogen in Coal Devolatilization," Fuel, 57, 749 .

Strobel, T.M.; Hurley, J.P. "Coal-Ash Corrosion of Monolithic, Silicon Carbide Based Refractories," In Proceedings of the Symposium on Ash Chemistry in Fossil Fuel Processes; American Chemical Society National Meeting, Chicago, IL August 22-27., 1993; in press. 
Ubhayakar, S.K., D.B. Stickler, C.W. Von Rosenberg and R.E. Gannon, "Rapid Devolatilization of Pulverized Coal in Hot Combustion Oases," 16th Symposium (International) on Combustion, The Combustions Institute, Pittsburgh, PA, 427. 


\section{APPENDIX A \\ CONCEPTUAL DESIGN \\ MAJOR EQUIPMENT LISTS}

Table A-1 Coal Handling and Preparation

Table A-2 Flue Gas Desulfurization

Table A-3 Plant Steam and Water 
Table A-1. Mnjor Equipmont Wat

\section{Coal Handling and Preparation}

\begin{tabular}{|c|c|c|c|}
\hline $\begin{array}{c}\text { Iten } \\
\text { Numer } \\
1\end{array}$ & $\begin{array}{l}\text { Equipment Deseription } \\
\text { Dump Hopper }\end{array}$ & 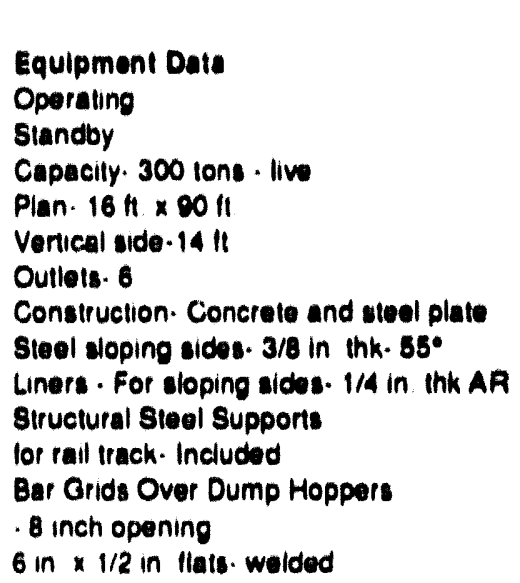 & $\begin{array}{c}\text { Number } \\
\text { Required } \\
1 \\
0\end{array}$ \\
\hline 2 & Coal Silo & 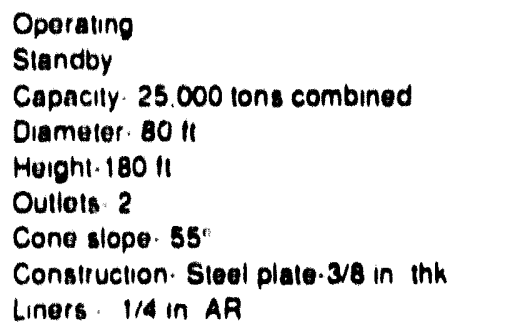 & $\begin{array}{l}2 \\
0\end{array}$ \\
\hline 3 & Sump Pump & $\begin{array}{l}\text { Operaling } \\
\text { Standby } \\
\text { Type Vortical Sump } \\
\text { Flow. } 150 \mathrm{gpm} \\
\text { TOH. } 7011\end{array}$ & $\begin{array}{l}2 \\
0\end{array}$ \\
\hline 4 & Tunnel Ventilation Fan & $\begin{array}{l}\text { Operaling } \\
\text { Slandby } \\
\text { Flow } 12000 \text { selm } \\
\text { SP } 2 \text { in waler }\end{array}$ & $\begin{array}{l}2 \\
0\end{array}$ \\
\hline s & $\begin{array}{l}\text { Dust Exiraction Fan } \\
\text { Dump Hopper Area }\end{array}$ & $\begin{array}{l}\text { Operating } \\
\text { Standby } \\
\text { Flow. } 18000 \text { sclm } \\
\text { AP: } 12 \text { in water }\end{array}$ & $\begin{array}{l}1 \\
0\end{array}$ \\
\hline 6 & $\begin{array}{l}\text { Dust Extraction Fan } \\
\text { Sampling Station Area }\end{array}$ & $\begin{array}{l}\text { Operaling } \\
\text { Standby } \\
\text { Flow } 18000 \mathrm{sclm} \\
\text { IP. } 12 \text { in water }\end{array}$ & $\begin{array}{l}1 \\
0\end{array}$ \\
\hline 7 & $\begin{array}{l}\text { Dust Extraction Fan } \\
\text { Silo Area }\end{array}$ & $\begin{array}{l}\text { Oporaling } \\
\text { Standby } \\
\text { Flow } 18000 \mathrm{sclm} \\
\text { SP } 12 \text { in wator }\end{array}$ & $\begin{array}{l}1 \\
0\end{array}$ \\
\hline
\end{tabular}

A-1 
Table A-1. Continued

\begin{tabular}{|c|c|c|c|}
\hline $\begin{array}{l}\text { Item } \\
\text { number }\end{array}$ & Equipment Descripilon & Equipment Data & $\begin{array}{l}\text { Number } \\
\text { Required }\end{array}$ \\
\hline$\bullet$ & $\begin{array}{l}\text { Dual Extracion Fan } \\
\text { Bin Area }\end{array}$ & $\begin{array}{l}\text { Operaling } \\
\text { Slandby } \\
\text { Flow } 6000 \text { sclm } \\
\text { IP. } 12 \text { in water }\end{array}$ & $\begin{array}{l}1 \\
0\end{array}$ \\
\hline 9 & Dump Hopper Feeders & $\begin{array}{l}\text { Operialing } \\
\text { Standby } \\
\text { Type Vibrating } \\
\text { Delivers to Dump Hopper Conveyor } \\
\text { Material. Coal. } 2 \text { in } \times 0 \\
\text { Capacily Adjusiable. } 010500 \mathrm{tph} \\
\text { Enclosure. Dusl tight } \\
\text { Liners Replaceable. } \\
\text { abraision resistant steel }\end{array}$ & $\begin{array}{l}6 \\
0\end{array}$ \\
\hline 10 & Dump Hopper Convoyor & $\begin{array}{l}\text { Operating } \\
\text { Siandby } \\
\text { Typu Boll Convoyor } \\
\text { Capacily } 2000 \mathrm{iph} \\
\text { Widih } 60 \mathrm{in} \\
\text { Lenglit } 9011 \\
\text { Speitd } 650 \mathrm{lpm} \\
\text { Lill. Nil }\end{array}$ & $\begin{array}{l}1 \\
0\end{array}$ \\
\hline 21 & Transler Conveyor & $\begin{array}{l}\text { Opuraling } \\
\text { Slandty } \\
\text { Type Boll Conveyol } \\
\text { Capacily } 2000 \mathrm{lph} \\
\text { Widin } 60 \mathrm{in} \\
\text { Longth } 30011 \\
\text { Lill } 6011 \\
\text { Speod } 650 \mathrm{lpm}\end{array}$ & $\begin{array}{l}1 \\
0\end{array}$ \\
\hline 12 & Bell Scala & $\begin{array}{l}\text { Oporniting } \\
\text { Slandby } \\
\text { Conpacily } 2000 \mathrm{iph} \\
\text { Boll widih } 60 \mathrm{in}\end{array}$ & $\begin{array}{l}1 \\
0\end{array}$ \\
\hline 23 & Tramp lion Mugnal & $\begin{array}{l}\text { Operaling } \\
\text { Standhy } \\
\text { Type Soll Cleaning } \\
\text { Boll Widih } 60 \mathrm{in} \\
\text { Coal Slronm Flow rale } 2000 \mathrm{iph} \\
\text { Coal size } 4 \text { in }\end{array}$ & $\begin{array}{l}1 \\
0\end{array}$ \\
\hline 24 & Silo Foad Convoyor & 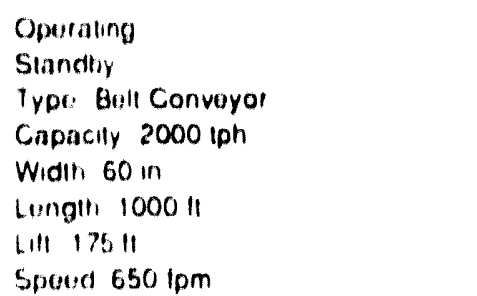 & $\begin{array}{l}1 \\
0\end{array}$ \\
\hline
\end{tabular}


Table A-1. Continued

Item

13 Sampling Syatem

16 Molorized Gate

17 Vibrating Bin Bolloms

18 Reclaim Foeders

2. Reclaim Conveyor

20 Bin Fead Convoyor

21 Dump Area Dust

Suppression system

22 Dusi Collecior
Dump Hopper Area
Equipment Dato

Operating
Standby
Coal Size 2 in $\times 0$
Flow rate- 2000 iph Main Belt
On.Line Coal Analyzer
Includes Sampling Diventer

Operating

Standby

Type wo way

Coal llow. $2000 \mathrm{tph}$

Operaling

Siandby

Type Kinergy or equal

Oparating

Slandby

Typo Belt Fueder

Capacily. $100 \mathrm{tph}$

Widih. 42 in

Lengih $25 \|$

Lill. nil

Spood $100 \mathrm{tpm}$

Oporating

Sinndby

Type Boll Conveyor

Copacily $100 \mathrm{tph}$

Width 24 in

Longih 47511

Lill. 50

Speod $250 \mathrm{lpm}$

\section{Opeining}

Slandby

Type: Bull Conveyor

Capacily $100 \mathrm{lph}$

Widih 24 in

Longth 175 II

Lill. 40

Speod. $250 \mathrm{lpm}$

\section{Oporaling}

Standby

Includos Prportioning pump 5 gpm.

Mixing tank Distribution Pump 200 gpm.

spray nozzles

Johnson Marsh. Chemjol or equal

Oporiting

Slandby

Typo Bag house

Filler Area 600089 il

Flow $18000 \mathrm{sclm}$

Prossure drop 6 in (Water)

A.3
3

8

2

Number

Required

\section{2}

1

0

0

0 
Table A-1. Concluded

\begin{tabular}{|c|c|c|c|}
\hline $\begin{array}{l}\text { Item } \\
\text { Number }\end{array}$ & Equipment Description & Equipment Dala & $\begin{array}{l}\text { Number } \\
\text { Required }\end{array}$ \\
\hline 23 & $\begin{array}{l}\text { Dust Collector } \\
\text { Sampling Station Area }\end{array}$ & $\begin{array}{l}\text { Operaling } \\
\text { Standby } \\
\text { Type. Bag house } \\
\text { Filler Area. } 6000 \text { sq. } 11 \\
\text { Flow. } 18000 \text { sclm } \\
\text { Pressure drop. } 6 \text { in (Weter) }\end{array}$ & $\begin{array}{l}1 \\
0\end{array}$ \\
\hline 24 & $\begin{array}{l}\text { Dust Collector } \\
\text { Silo Area }\end{array}$ & $\begin{array}{l}\text { Operating } \\
\text { Slandby } \\
\text { Type. Bag house } \\
\text { Filler Aren. } 6000 \mathrm{sq} 11 \\
\text { Flow. } 18000 \mathrm{cclm} \\
\text { Pressure drop. } 6 \mathrm{in} \text { (Walor) }\end{array}$ & $\begin{array}{l}1 \\
0\end{array}$ \\
\hline 23 & $\begin{array}{l}\text { Dust Collector } \\
\text { Bin Area }\end{array}$ & $\begin{array}{l}\text { Operaling } \\
\text { Standby } \\
\text { Type Bag house } \\
\text { Filler Area. } 3000 \text { sq it } \\
\text { Flow } 6000 \text { sctm } \\
\text { Prossuru drop } 6 \text { in (Water) }\end{array}$ & $\begin{array}{l}1 \\
0\end{array}$ \\
\hline 26 & Day bins & $\begin{array}{l}\text { Operaling } \\
\text { Siandby } \\
\text { Diameler } 2511 \\
\text { Height } 4511 \\
\text { Cone slope } 55 \\
\text { Consiruclion Steol plate } 3 / 8 \text { in thick } \\
\text { Linors } 1 / 4 \text { in AR }\end{array}$ & $\begin{array}{l}2 \\
2\end{array}$ \\
\hline 27 & Pulvarizer & $\begin{array}{l}\text { Cporating } \\
\text { Standby } \\
\text { Capacily } 28 \mathrm{Wh} \text { (with integral clatlifier) } \\
\text { Molor } 1000 \mathrm{HP}\end{array}$ & $\begin{array}{l}2 \\
2\end{array}$ \\
\hline 20 & PA blowor & $\begin{array}{l}\text { Operaling } \\
\text { Slandby } \\
\text { Flow rate } 42,300 \mathrm{actm} \\
\text { Discharge pres } 34 \mathrm{psig} \\
\text { Inlel pros atmospheric }\end{array}$ & $\begin{array}{l}1 \\
0\end{array}$ \\
\hline 29 & Fired healer & $\begin{array}{l}\text { Oporaling } \\
\text { Slandby } \\
\text { Duly } 1280 \mathrm{MMBlu} / \mathrm{hr} \\
\text { Fuol natural gas } \\
\text { Flow } 200 \mathrm{sclm}\end{array}$ & $\begin{array}{l}1 \\
0\end{array}$ \\
\hline
\end{tabular}


Table A-2. Major Equipment List

Flue Gas Desulfurization

Item
Number Equipment Description

1 Absorber Tower

2

Recycle Pumps

3

Oxidation Air Compressor

4

Flue Gas Booster Fan

5

Scrubber Bleed Pump

6

\section{Equipment Data}

Number

Required

Operating

Standby

Vertical counter current spray tower

$21 \mathrm{ft}$ I.D. by $120 \mathrm{ft} T / \mathrm{T}$

Carbon steel with rubber lining, or FRP

construction

Includes horizontal chevron mist eliminator,

air sparger, 4 spray banks and M.E. water

wash system

\author{
Operating \\ Standby \\ Horizontal centrifugal pumps \\ $5,000 \mathrm{gpm}$ each \\ $120 \mathrm{f} \mathrm{TDH}$ \\ Rubber lined carbon steel \\ 250 HP motor
}

2

0

Operating

Standby

Multi-stage, centrifugal air compressor

complete with controls, motor, pre-filter

and after-humidifier

$4.000 \mathrm{cctm}(300 \mathrm{lb} / \mathrm{min})$

40 psia

$400 \mathrm{HP}$ motor

Carbon Steel materials

Operating

2

Standby

Axial type fan

$250,000 \mathrm{actm}$ at $240^{\circ} \mathrm{F}$

13 inch W.C.

$800 \mathrm{HP}$ molor

Operatıng

2

Standby

2

Centrifugal type pump

$200 \mathrm{gpm}$ each

50 psi head

Rubber lined carbon steel

10 HP motor

Operating

Standby

2

Total capacity of 10,000 tons or 60 days

Concrete construction with steel lined shutes

Two supply points; includes leeders and

feed conveyor
8

2

1 
Table A-2. Continued

Item

Number Equipment Description

$7 \quad$ Limestone Day-bin

8 Limestone Receiving Area

Stack

11

Limestone Ball Mill

12

Limestone Slurry Tank

\section{Equipment Data}

Operatıng

Standby

200 ton capacity or 30 hours

$14 \mathrm{H}$ diameter by $30 \mathrm{Ht}$ straight side

Carbon steel material

Includes displacement filter and bin discharger $1,000 \mathrm{acfm}$ baghouse, $5 \mathrm{HP}, 800 \mathrm{sf}$ area

Operating

Standby

Covered dump pad for rail car or truck

Mobile unloading conveyor $10 \mathrm{HP}$ motor

Mobile slacker $20 \mathrm{HP}$ motor

100 ton bin with reclaim feeder 20 HP motor

Conveyors are 24 inch belt width

$1.000 \mathrm{actm}$ baghouse, $5 \mathrm{HP}, 800 \mathrm{sf}$ area

Operating

Standby

Ground conveyor; 24 inch belt; $200 \mathrm{ft}$ length

Inclined 24 inch belt; $100 \mathrm{ft}$ lenght, 15\%

incline

2.000 actm baghouse, 5 HP, 800 sf area

Operaling

Standby

$500.000 \mathrm{actm}$ at $125^{\circ} \mathrm{F}$ trom FGD; 555,000

actm at 180 "F from gas turbine

Discharge temp of $152^{\circ} \mathrm{F}$

Discharge velochiy $90 \mathrm{fps}$

15 If FRP lined carbon steel liner

$17 \mathrm{ft}$ diameter shell at top, tappers to $28 \mathrm{ft}$

diameter at base; concrete material

Height of $300 \mathrm{ft}$

Operalıng

Standby

Feed rate of 200 tons per day

Ground product : 90 percent by weight

less than 200 mesh

$200 \mathrm{HP}$ motor

Includes hydroclone classifier

Operating

Standby

Contains 20 percent by weight limestone

slurry, or 8 hours storage

58.000 gallon capacity

$22 \mathrm{fl}$ diameter by $24 \mathrm{ft}$ straignt side

Carbon steel material

Includes agitators and bridge: $50 \mathrm{HP}$

Operating

Standby

1

Services hydroclone overflow and filtrate

$16 \mathrm{ft}$ diameter by $12 \mathrm{ft}$ straight side

1 hour capacity at maximum flow

Carbon steel material

Number

Required

1

0

1

0

1

0

1 


\section{Table A-2. Concluded}

Item

Number Equipment Description

14

Hydrocione

15

Gypsum Slurry Tank

16

Gypsum Filter

\section{Equipment Data}

Number

Required

Operating

Standby

Dewaters gypsum slurry to about 40 percent moisture

Krebs model d10b, 13.5 inch O.D. by $4 \mathrm{th}$ high $300 \mathrm{gpm}$

Carbon steel material with resin lining

\section{Operating}

Standby

Contains the dewatered hydroclone slurry

$22 \mathrm{ft}$ diameter by $24 \mathrm{ft}$ straight side

60.000 gallon capacity or 8 hours at max. How

Carbon steel material with resin lining

Includes agitator and bridge $75 \mathrm{HP}$

\section{Operating}

Slandby

Horizontal vacuum belt filter

11 tph of dry solids capacity

44 st filtration area

Carbon steel material with resin lining

includes vacuum system, slurry handling system,

pumps discharge conveyor and controls

$5 \mathrm{HP}$ motor

$150 \mathrm{HP}$ vacuum pump 
Table A-3. Major Equipment List

Plant Steam and Water

Item

Number
Equipment Description

1

FGD Process Water Tank

FGD Process Water Pump

Blowdown Makeup Water Tank

\section{Operating}

Standy

Size 8' Dia x $12^{\prime}$ High

Service water ( $4 \mathrm{hr}$ storage time)

Material Carbon Steel

Equipment Data

Number

Required

Operatıng
Standy

Size: $10^{\prime}$ Dia $\times 15^{\circ}$ High

Service: water supply for

limestone slurry

Sizing criteria: $1 \mathrm{hr}$

retention time@ maximum flow

Flow: $65,000 \mathrm{lb} / \mathrm{hr}$

Material: Carbon Steel

Operatıng

1

Type: Horizontal, centrifugal

Material Carbon Steel

Flow $150 \mathrm{gpm}$

Diff pres: 20 psi

Motor $3 \mathrm{HP}$

1

0

Operatıng

Standy

Type Horizontal, centrifugal

Flow $20 \mathrm{gpm}$

Diff pres. 100 psi

Motor $3 \mathrm{HP}$

5

Condensate Storage Tank

Operatıng

Standy

Size $20^{\prime}$ Dia $\times 12^{\prime}$ High

Material: Carbon Steel

Service water ( $30 \mathrm{~min}$ storage time)

Operating

Standy

Service water ( $4 \mathrm{hr}$ storage time)

Material Carbon Steel 
Table A-3. Continued

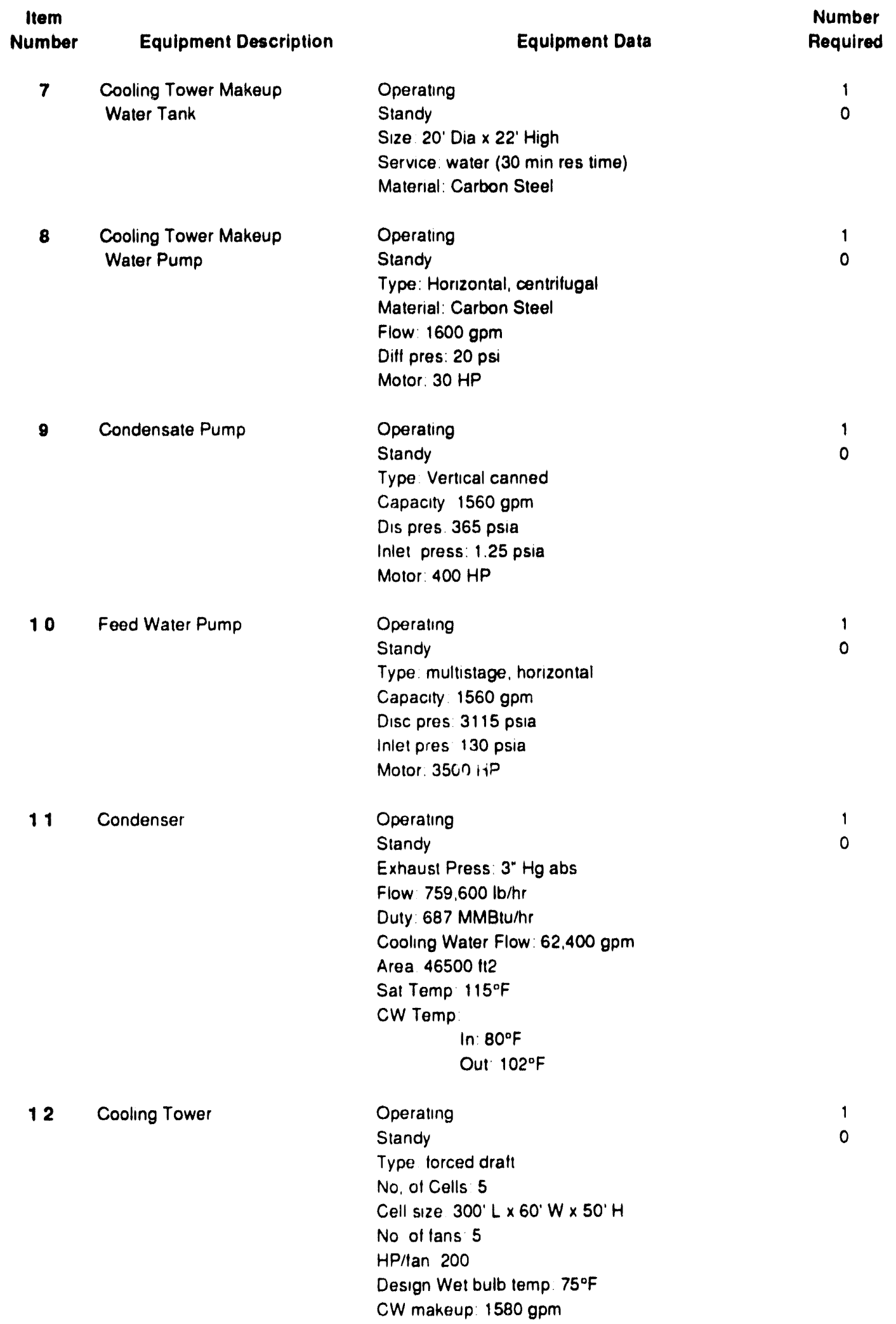


Table A-3. Concluded

Item
Number

Equipment Description

Cooling Water Pump

13

$$
\text { Cooling Water Pump }
$$

14 Plant Instrument Air

Compressor

\section{Equipment Data}

Operatıng

Standy

Type mixed

Flow $31,200 \mathrm{gpm}$ (per pump)

Head 65'

Motor $582 \mathrm{HP}$

\section{Operatıng}

Standy

Flow 460 actm

Disc pres: 115 psia

Inlet pres: atmospheric

Motor $125 \mathrm{HP}$
Number

Required

\section{2}

0

1

0 

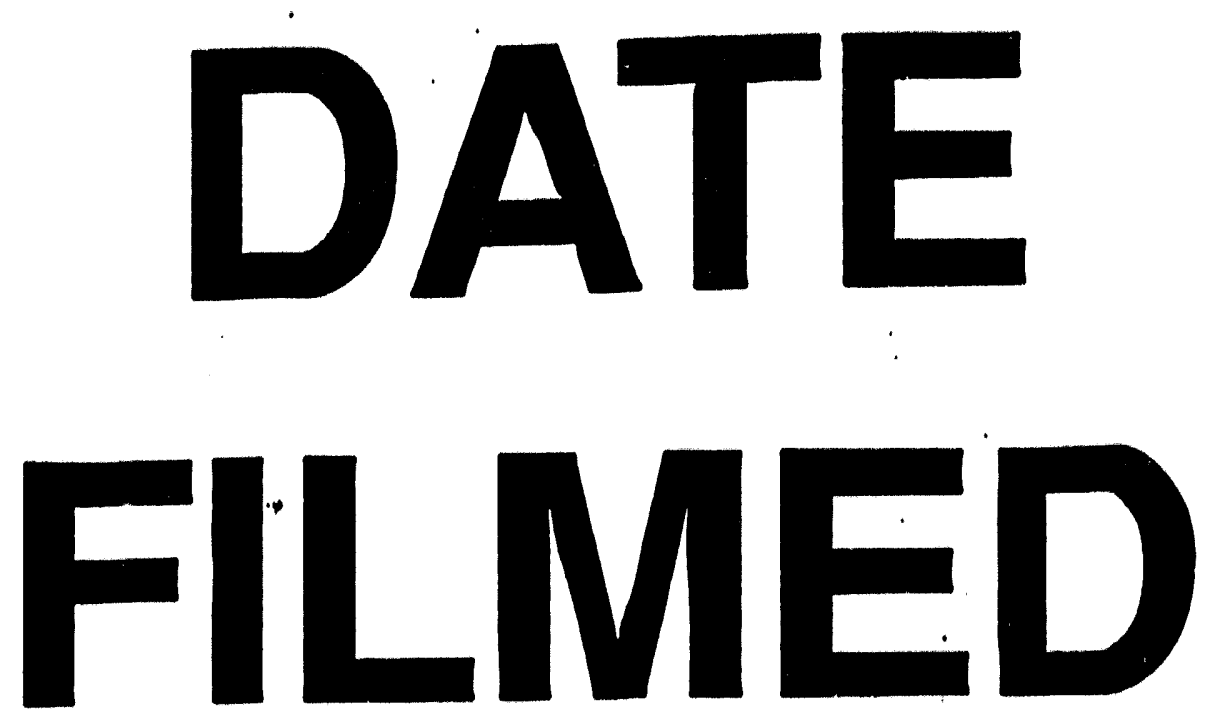

$1 / 11 / 94$
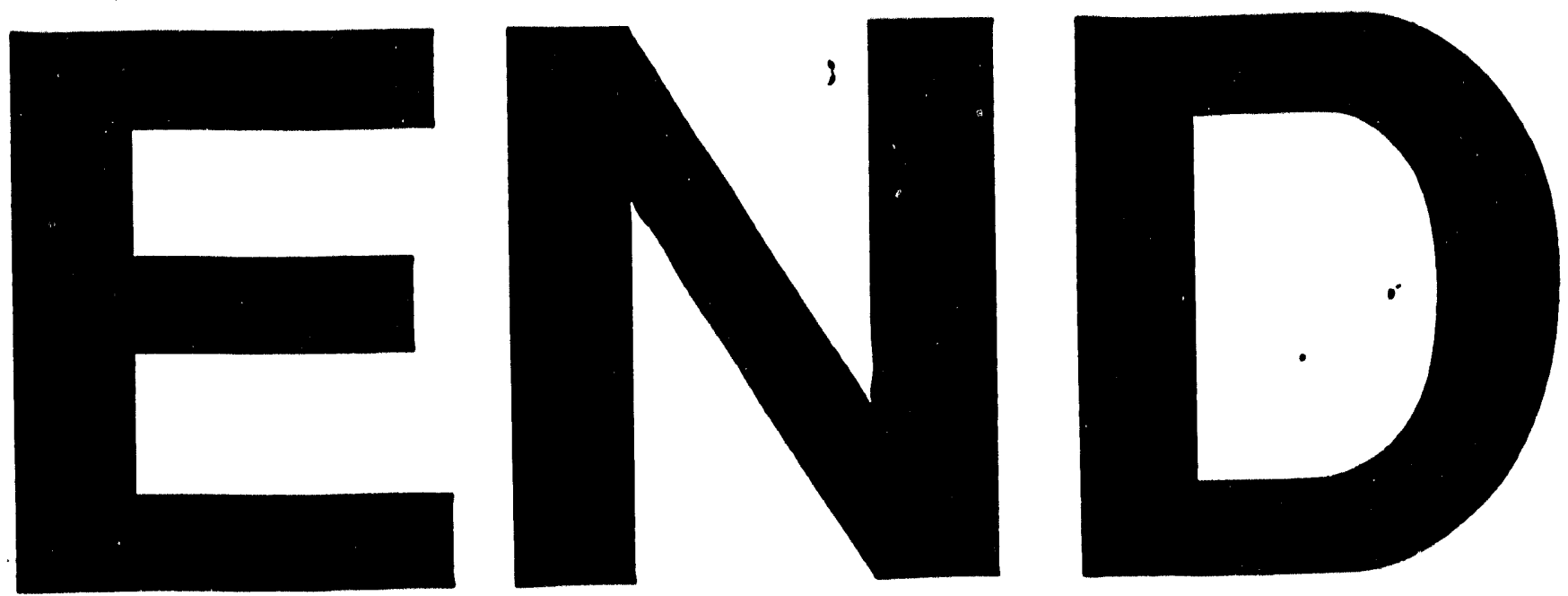

-

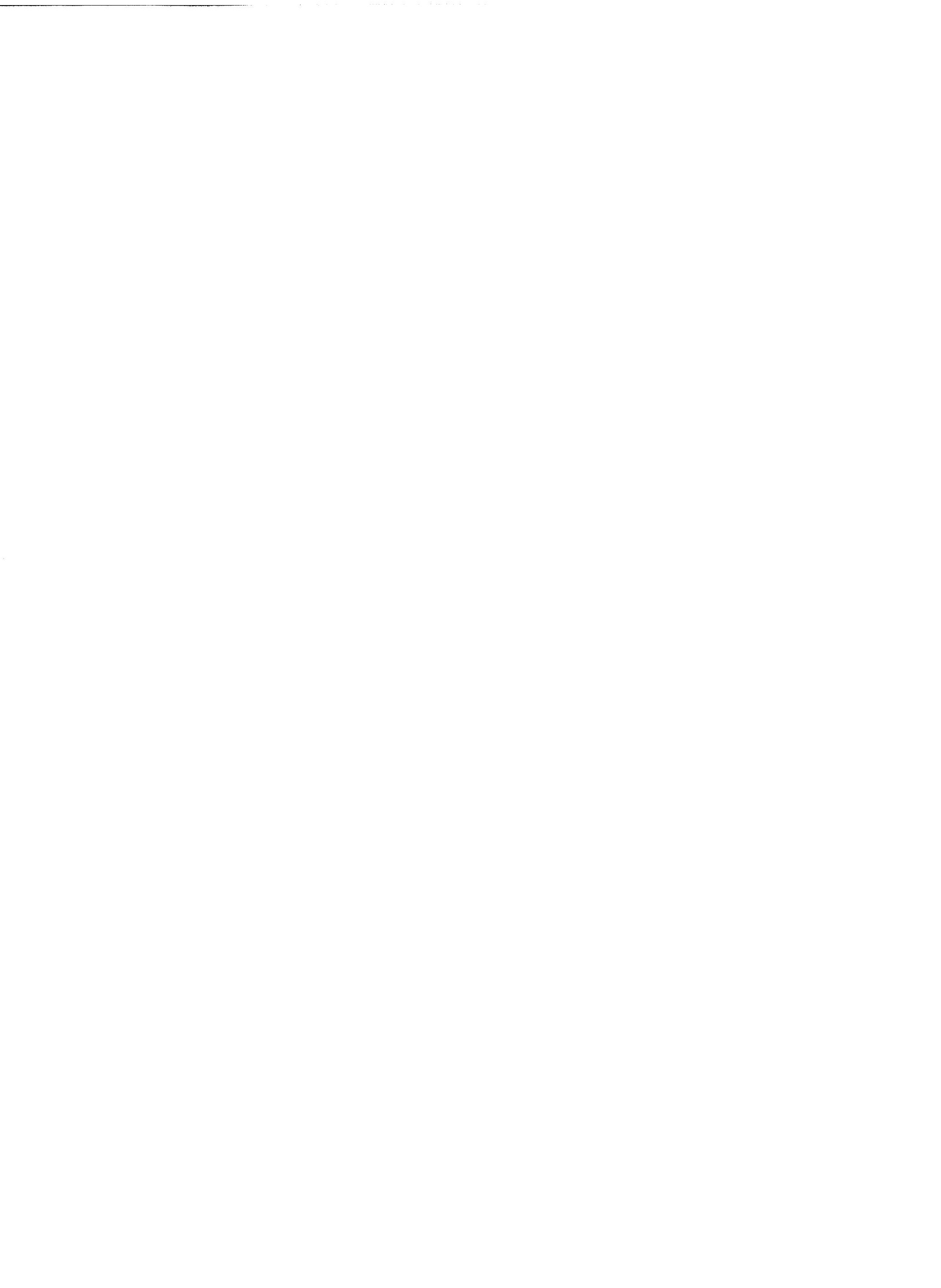

